\title{
Pastor J. H. Nissens erindringer og breve fra et ophold i Angel 1852-64
}

Ved Peter Kr. Iversen

\section{Indledning}

Johan Henrik Nissen blev født i Sorø den 24. februar 1820 som søn af akademigartner Hans Ditlev Nissen og Agathe Marie, født Reeberg. Han blev student fra akademiet 1837 sammen med bl.a. den såvel i erindringer som breve omtalte auditør i Flensborg, M. A. Monrad. Fra sine gymnasieår kendte han også om end flygtigt, den lidt ældre A. Regenburg, som samtidig med, at Nissen 1837 blev student, tog den såkaldte "anden eksamen “ på Sorø, der havde samme værdi som den filosofiske prøve ved Københavns Universitet. Nissen studerede derefter teologi i København og blev cand. teol. med første karakter i januar 1844. Som så mange andre unge teologer dengang begyndte han som huslærer. Han kom til Humble på Langeland, hvor han i tre år underviste to af provst Plesners sønner og hvor han "uden dog ligefrem at have nogen forretning ved præsteembedet på forskellig måde lærte en landmenigheds forhold at kende«. Den yngste af de to provstesønner fulgte ham 1847 til Odense Katedralskole, hvor han blev konstitueret adjunkt og efter et års forløb, 1848, fastansat. Han kom til at undervise i religion i alle klasser og underkastede sig hos den fynske biskop prøverne i at katekisere, d.v.s. undervise $\mathrm{i}$ religion og $\mathrm{i}$ at prædike, - prøver, som han begge bestod med første karakter. Som forberedelse til en senere præstegerning prædikede han på Odense fattiggård og i Skt. Hans kirke.

Nissen var derfor velkvalificeret til et præstembede, da han d. 27. august 1851 skrev til departementschef A. Regenburg og spurgte, om han kunne få et embede som præst ved en dansktalende menighed i Sønderjylland. Han var interesseret i Halk, som var vakant, men han kom dog, som det vil ses af erindringerne og brevene i stedet til det sprogblandede sogn Hyrup i Angel, hvor han var præst 1852-59, og derfra til nabosognet Husby, hvor han virkede til sin afsættelse den 15. marts 1864. Allerede den 6. maj samme år fik han imidlertid embede $\mathrm{i}$ Føns på Vestfyn, og dette embede ombyttede han 1875 med Vissenbjerg, hvor han blev pensioneret 1890. Han døde d. 20. maj $1904 \mathrm{i}$ en alder af 84 år. I hans ægteskab med Cathrine Sophie Hedvig Døllner, der var født d. 20. juni 1819 som datter af stiftsgartner Carl Fr. 


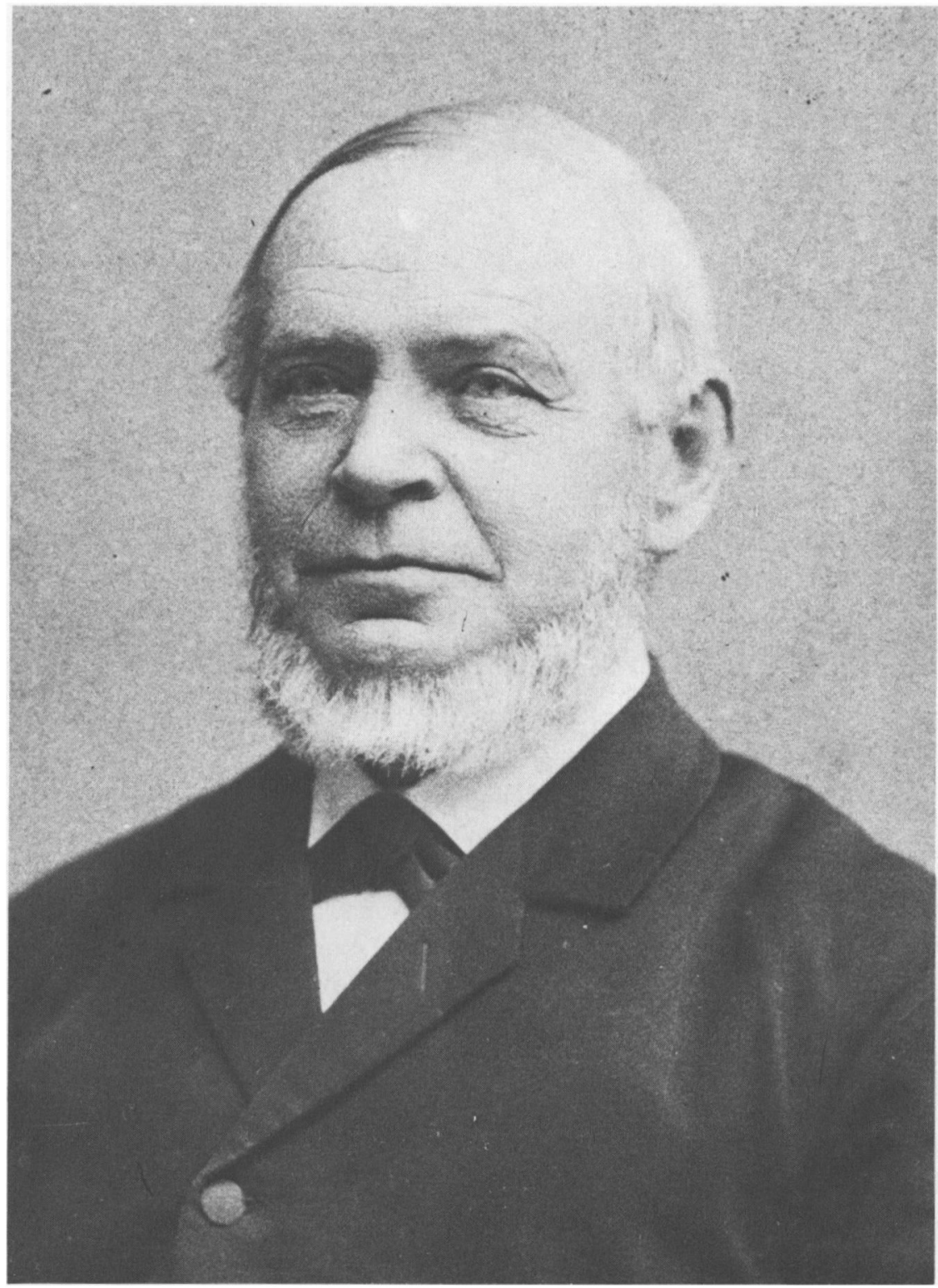

J. H. Nissen.

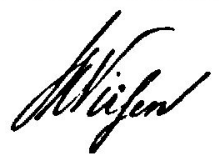

(Fot. af G. P. Jacobsen, Odense, Vissenbjerg prastegärd) 
Døllner og hustru Hedvig Marie, f. Møller, voksede der en stor børneflok op. Ved bortrejsen fra Husby var der seks børn i live.

Erindringerne fra Hyrup og Husby i årene 1852-64 er - som Nissen oplyser i sit forord - nedskrevet i hans 80. år, altså 35-45 år efter Angler-opholdet. Det kan derfor ej heller næppe undre, at oplevelserne fra de for ham så begivenhedsrige år er kommet til at stå i et ganske særligt skær, og det er derfor heller ikke uinteressant at sammenligne erindringerne med hans samtidige breve til departementschef $\mathrm{A}$. Regenburg. Nok så meget som erindringerne afspejler disse breve dagligdagens ofte noget trivielle og til tider lidt ubehagelige arbejde, men dog også med opmuntrende glimt af arbejdet for danskhedens sag. Nissen var helhjertet tilhænger af Regenburgs sprogpolitik, og han hørte til dennes kreds af håndplukkede Sorø-studenter, der som præster eller på andet embedsplan var med til at gennemføre den politik, som en senere tid har lidt svært ved at vurdere positivt.

Erindringerne er dateret 27. april 1899, men er her gengivet efter en afskrift, der må være omtrent samtidig. Denne afskrift blev i september 1975 indlånt til landsarkivet i Åbenrå fra apoteker N-O. Arndal, Højer, til kopiering og senere afleveredes en maskinskrevet transkription af manuskriptet foretaget af fhv. rektor Aksel Arndal, men allerede forinden var manuskriptet ved min foranstaltning blevet renskrevet på maskine og konfereret med henblik på udgivelse. Erindringerne er så levende fortalt, at de for mig syntes velegnede til udgivelse i Sønderjyske Årbøger.

Under mit arbejde med klargøringen og kommenteringen af manuskriptet var det nærliggende for mig at medtage de breve fra $J$. H. Nissen til departementschef A. Regenburg, der ligger i dennes arkiv i Rigsarkivet og som så levende supplerer erindringerne. Sikkert vil der også i lokale embedsarkiver kunne findes breve og indberetninger fra Nissen, men det ville i denne forbindelse føre for vidt at medtage dem her. I forvejen er brevene til Regenburg af et anseligt omfang, og ved gengivelsen her er da også mindre væsentlige afsnit, mest af mere privat karakter udeladt eller gengivet $i$ kort refererende form. Dette fremgår af teksten, hvor referaterne er sat med kursiv.

Ved transkriptionen af erindringer og breve er fulgt ensartede retningslinier. Den afskrift, hvorefter erindringerne er gengivet, og som må hidrøre fra omkring århundredskiftet, er næppe helt nøjagtig, idet udsagnsord snart er bøjet i flertal, snart ikke. Både for erindringer og breve galder ved nærværende udgivelse, at de $\mathrm{i}$ det hele og store er gengivet bogstavret. I navneord er der dog anvendt små begyndelsesbogstaver og aa er erstattet med å-tegn. Endvidere er tegnsætningen og bøjningen af udsagnsord normaliseret. 


\section{Erindringer}

Den efterfølgende fortælling over mine oplevelser 1852-64 i Slesvig er først nedskrevne 35 år efter. Jeg går nu i mit 80de år, og som naturligt er, er min hukommelse i mange måder svækket ikke så lidt. Men erindringerne for hine år er friske og levende, dels gjorde de dages hændelser - især fra februar og marts 1864 - et mægtigt indtryk på mig; dels er i årenes løb meget af dem bleven mundtlig fortalt, og dels er minderne atter og atter dukkede op og år efter år opfriskede, så at hvad her fortælles, hverken er et udsmykket fantasifoster eller i nogen måde forvansket, men fuldt og rent sandheden tro. Tidsangivelsernes nøjagtighed støtter sig derfor på notater i almanakken.

Fortællingen har ingen almindelig interesse, men er kun skreven til oplysning om de tider for børn og børnebørn, slægt og venner.

\section{Motto:}

Vel dig, som gik med ham i livets trængsler.

For dig går dødens port på lette hængsler!

Vel mig en stav jeg kan af korset skære.

$\mathrm{Da}$ går jeg let, hvor vejene er svære.

(Salme nr. 788, Chr. Richardt)

\section{Min kaldelse til prast i Hyrup}

I efteråret 1851 blev der af en skolekammerat (auditør Monrad) ${ }^{1}$ i Flensborg mig meddelt, at jeg ville kunne få ansættelse som præst $\mathrm{i}$ de blandede distrikter i Flensborg Provsti. Jeg var den gang adjunkt i Odense og kunne, skønt e. 8 års candidat med laud, endnu ikke i nogle år vente ansættelse i kongeriget. Tilbudet var da indbydende, men inden jeg bestemte mig til at modtage det, måtte jeg først kende sprogforholdene i Angeln; jeg rejste da til Flensborg; det viste sig, at der var 2 embeder, Kværn og Hyrup, det første 2 mil, Hyrup 1 mil sønden for Flensborg, som jeg kunne vælge imellem. Oberst Fuhrmann ${ }^{2}$ lå da i Flensborg, og han, som havde befordring til sin rådighed, kørte da med mig til Hyrup, et lille sogn bestående af 3 byer, liggende i en linie på et højdedrag; vi kørte igennem alle 3 byer; hvor vi traf mennesker på eller $i$ husene ved vejen, standsede vi, og Fuhrmann førte ordet, tiltalende dem alle på dansk og fik ligeledes allevegne svar på dansk; det var selvfølgelig mig en glædelig overraskelse, og mine betænkeligheder ved ifølge sprogreskriptet, der da blev indført, at komme til at prædike dansk hveranden søndag i en menighed, der hidtil kun havde haft tysk til kirke- og skolesprog, var derved vasentlig overvundne. ${ }^{3}$

Jeg vendte da tilbage til Flensborg, fortalte Regenburg, ${ }^{4}$ under hvem 
Departementschef Th. A. J. Regenburg, foto 1859.

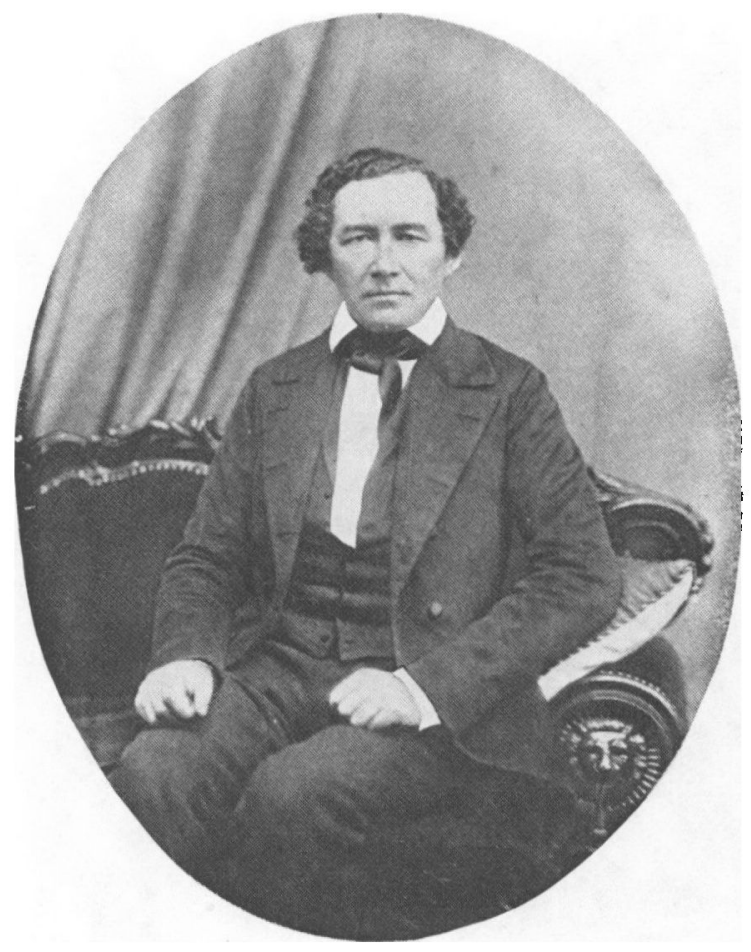

departement kirke- og skolesager sorterede, at jeg med egne øren havde forvisset mig om, at hyrupperne var dansktalende, og at for så vidt valget mellem Kværn og Hyrup stod til mig, foretrak jeg Hyrup, skønt ringere $i$ indtægter. Jeg rejste da tilbage til Odense med den forvisning, at jeg ville blive kaldet til Hyrup, og juleaften 1851 kom udnævnelsen til mig - »en skøn julegave«.

I februar afgik jeg fra Odense; inden afrejsen gjorde skolens lærere afskedsgilde for mig. Arden ${ }^{5}$ havde skrevet sangen; alle skolens klasser - jeg havde undervist i religion i dem alle - gav mig en smuk erindringsgave; øverste klasse - Kalkars bibel, de andre forskellige stykker sølvtøj; sukkerskålen med det hvide glas, flødekande, jordbærske etc., som alt naturligvis er $i$ behold og fremdeles må bevares i familiens eje.

Søndag sexagesima - 15 . februar 1852 , blev jeg ordineret $i$ Flensborg med 2 andre af provst Aschenfeldt ${ }^{6}$ i Nicolai kirke, hvor jeg for første gang prædikede på tysk - efter sigende uden anstød - og næste søndag indsat $i$ Hyrup kirke. Et par dage forinden kørte jeg med Jacob Hansen ${ }^{7} 2$ den præst i Grumtofte til Hyrup for at se kirken, min formand Back ${ }^{8}$ var da endnu i 


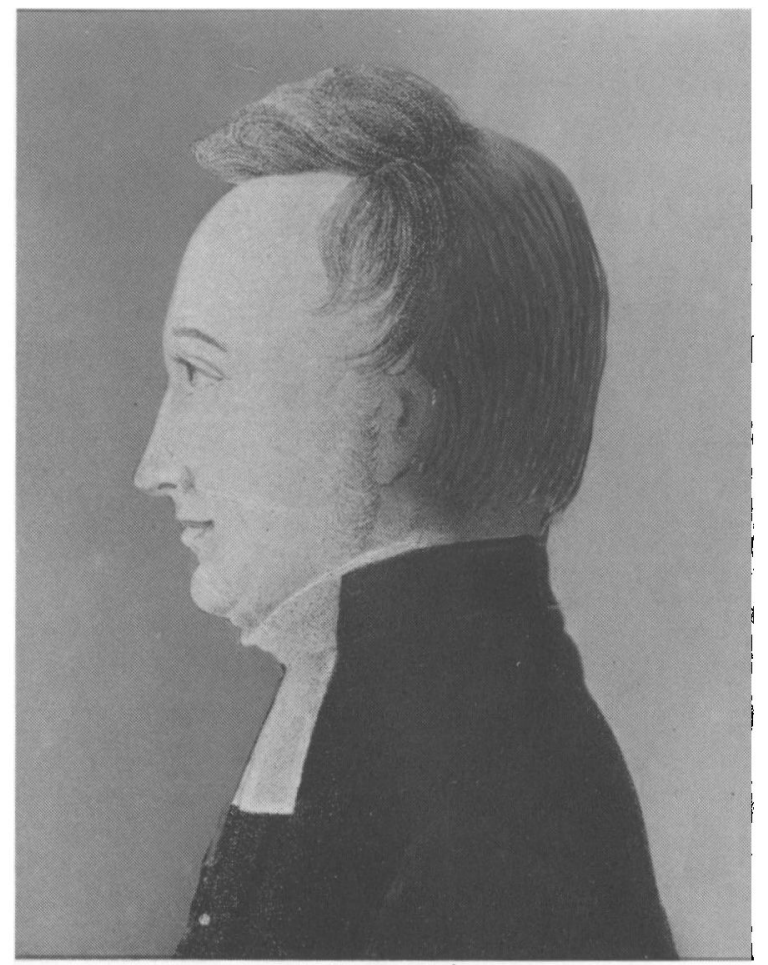

Provst C. C. J. Asschenfeldt. (Dansk Centralbibliotek for Sydslesvig).

præstegården; ham ønskede jeg ikke at stå ansigt til ansigt med, han var slesvigholstener, men som en hyrupper sagde, en gammel snu karl, der havde vogtet sig for at undersk rive noget oprørsdokument og derfor gik af med pension og tog bolig i nabosognet Husby; vi kørte da lige op til kirken, fik nøglen til den hos skolelæreren; da vi var kommet ind på kirkegården, kom en ældre, stor bonde os i møde, der tiltalte os med de ord: "God daw! en af dem er vistnok vor nye præst “. Da jeg så gav mig tilkende, udbrød han: "Så vær velkommen," og gav mig et kraftigt håndtryk. Hans gård lå lige op til kirkegården; han hed Gregers Nissen, var dansksindet tilgavns, som hans nærmeste naboer, og den stadigste kirkegænger, forsømte aldrig nogen gudstjeneste, hvad enten den var tysk eller dansk, og en trofast ven af os $i$ alle de år, også efter at jeg var flyttet til Husby, hvor han ikke kunne begribe, at "jeg ville søge hen og være blandt de tyskere.«

Så snart som muligt efter min indsættelse kom "moder “ med vor Agathe til Hyrup til en tarvelig lille præstegård, halvdøre til indgang fra gården og ud til haven, 6 tildels umalede værelser; men den var smukt beliggende på 


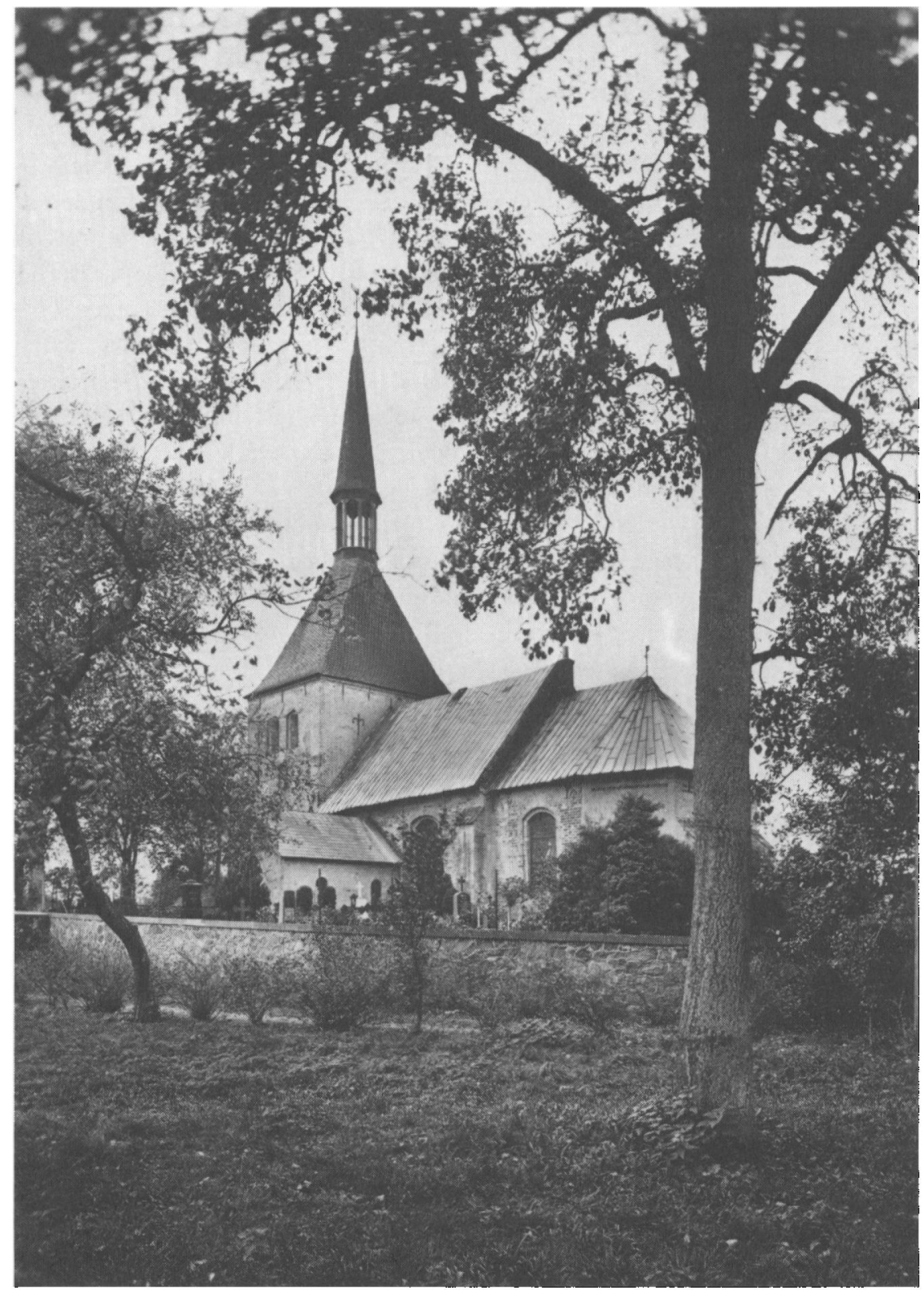

Hyrup kirke. (Dansk Centralbibliotek for Sydslesvig).

højdedraget, med et vænge adskilt fra kirken, der var lille, med et højt slankt spir, omgivet af høje smukke træer. Den lå midt i sognet, der med sine 3 byer 
kun havde c. 600 indbyggere. Kirken, der ligesom præstegå rden, ejedes af menigheden og altså vedligeholdtes af den, blev i et af mine første embedsår restaureret med ikke ringe udgift, nymalet og bænkene fornyede. Hver familie havde sine bestemte pladser i kirken; disse gav anledning til nogen strid $\mathrm{i}$ menigheden dels dermed, at kådnerne o: husmændene ikke var fornøjede med, at gårdmændene ikke ville afstå nogle af deres pladser nede i kirken til dem, men kun gav afkald på deres pladser på pulpituret til afbenyttelse af kådnerne. Ved hensigtsmæssig forandring af siddepladserne på pulpituret og ved, at jeg også gav 3 pladser nede i kirken mod 3 pladser på pulpituret, og at min kone stadig tog plads på pulpituret, forsonedes kådnerne, og klagerne forstummede. Efter kirkens restauration kom præstegården; ved forskellige forandringer af værelserne blev lejligheden betydelig forbedret og forskønnet, og senere blev der bygget en ny lade. I det hele levede vi der i om end ikke fede, så gode og lykkelige år der. Det langt overvejende antal af beboerne var dansksindede og alle de indfødte dansktalende på enkelte undtagelser nær, som var blevne så fortyskede, at de nødig ville tale dansk; vort omgangssprog var altså så at sige udelukkende dansk, kun med et par tyske præstesønner og en for resten flink holstener, der boede der, talte jeg tysk. Var det vel ikke efter de flestes ønske, at der blev indført dansk skolesprog - dog med nogle tyske undervisningstimer - og blandet kirkesprog - dog således at alle kirkelige handlinger udførtes på det sprog vedkommende ønskede, erfarede de snart, at det faldt børnene meget lettere at blive underviste på dansk, og at de, der ville, også godt kunne forstå en dansk prædiken. Forholdet var således langt tåleligere og bedre end i de sydligere sogne; var der end altid flere ved den tyske gudstjeneste end den danske, så at med undtagelse af Rylskov var der neppe noget sogn i Angeln, hvor indførelse af dansk vakte mindre modstand og uvilje end her. - Intet i sammenligning med den modstand, tysk $\mathrm{i}$ tidligere år havde mødt, og hvorom Allen i sin bog: Det danske Sprog i Slesvig 1 st del, pag. 202 XIII har givet så vagtig oplysning. De vanskeligheder, jeg mødte, var derfor kun små $i$ sammenligning med, hvad mine kollegaer i de fleste sogne i Angeln havde at bekæmpe.

I Hyrup blev Marie født d. 30. august 1852 - Peter Christian, der døde 14 dage gammel, hvilke begge er velbevarede (sic!) og Johanne 8. april 1856 og Carl $1858, \dagger \mathrm{i}$ Vissenbjerg 1876.

\section{Husby $14 / 1-15 / 31864$}

Sognet grænsede umiddelbart til Hyrup og sprogforholdene væsentlig de samme, men langt flere tysksindede end i Hyrup.

Da kongen, Christian d. 8. 1846, havde forlangt embedsmandenes 
erklæring om sprogforholdene, udsendte amtmanden i Flensborg et cirkulære (se Allen 2den del, pag. 362), hvori han ligefrem beder dem at være "ham behjælpelig med den plan at levere bevis for, at det dansk, som tales i Flensborg amt, ikke kan gøre krav på at gælde som virkeligt dansk“. Opfordringen blev kun altfor villigt fulgt af præsterne, der alle mer eller mindre fornægtede eller forvanskede sandheden, så de, hvor de ikke kunne nægte, at dansk var folkesproget, betegnede det som en sprogblanding, fordærvet dansk, "afskyeligt patois", "kauderwalsch" etc., og der var kun en eneste tyskdannet præst, Simonsen' i Husby, som var sandheden tro; han erklærede: for det »langt overvejende flertal af beboere, der anslås til 1250, er dansk det daglige sprog, i omtrent 22 familier á 5 personer - altså 110 bliver plattysk brugt, men de fleste af disse kunne dog også tale dansk. Børnene i de tyske skoler beregnes til 350 - altså tilsammen af plattysktalende en sum af 460 , hvorved dog er at bemærke, at af disse børn de fleste efter konfirmationen lidt efter lidt går over til brugen af dansk «. Det var denne sandfærdige erklæring, der havde afgørende betydning for efter krigen 1850 at indføre dansk i skolerne - dog med flere timers ugentlig undervisning i tysk - og dansk afvekslende i kirken, dog således, at der var beboerne givet frit valg af sprog ved alle kirkelige forretninger. Pastor Simonsen blev imidlertid revet mere og mere med af det slesvigholstenske parti - der fandtes i præstearkivet breve til ham, hvor det hed: "Du er for god til at høre den danske propaganda til, du må blive vor “ -, og han blev en fuldblods slesvigholstener. På prædikestolen sammenlignede han Slesvigholsten med de siamesiske tvillinger, der kun kunne skilles med sværdet; en bonde fortalte mig, at da krigen var brudt ud, og en landstorm rejstes i Angeln for at modstå arvefjenden, som de kaldte de danske, ved Holnæs ved indløbet til Flensborg fjord, og vi husbyere skulle med, gik vi forbi præstegården i den tanke, at præsten ville komme ud og sige os, hvad dette tog til Holnæs skulle betyde - da blev han inde i sin stue; men var han kommet ud og havde blot sagt: »Det er dumt tøj, I har for - var vi alle gåede hver til sit - men som sagt han blev inde, og den næste dag sendte han sin karl til Rendsborg for at hente geværer til landstormen «. Samme prast havde i en fasteprædiken over Jesus i Gethsemane sagt - fortalte et ørenvidne - Erik Pedersen - mig: Da Jesus fremstillede sig for soldaterne og spurgte dem: "Hvem leder I efter? Efter Jesus af Nazareth " og han derpå svarede: "Det er mig" - således kan det også komme til at gå mig og føjede til, idet han rakte hånden i vejret med 3 udstrakte fingre: "at han da nok skulle følge frelserens fodspor efter «, men sagde bonden: »Det løfte glemte han fælt". Efter slaget ved Isted kom om natten nogle danske dragoner til degnen Hansen i Husby; ${ }^{10}$ han, som var en berygtet slesvigholstener, anede ikke udfaldet af slaget og åbnede vinduet og tiltalte dem: 
"Ihr lieben deutsche Brüder, seyd Ihr da, « hvorpå han fik en sådan tiltale af dragonerne, at han skyndsomst smækkede vinduet $i$, og for i natdragt ud af den modsatte side af huset over til præstegården, vækkede præsten, fortalte ham, hvad der var sket, og rådede ham til flugt. Han sagde just ikke strax at være tilbøjelig dertil, men overtaltes dog af konen - en forresten dansk født dame (Gerike) ${ }^{\prime \prime}$ - og fik i en fart klæderne på, hen til nabogården, og de 2 naboer, Peder Nissen og Erik Pedersen - 1 tysksindet og den anden dansksindet, som har fortalt mig hele historien - flygtede da sydpå med præsten. Da de kom ind i en lille skov, hvorigennem vejen fra Flensborg til Kappeln går, standsede pludselig præsten bestyrtet ved en indbildt larm og spurgte: "Hvad var dog det?«, hvortil den dansksindede bonde, Erik Pedersen, svarede: "Inte nov'et hr. pastor, det var itt andet end hjertet, der bankede i Dem«. - Det viste sig også at være blind alarm. Flugten fortsattes, hvorefter bønderne forlod ham, og præsten kom uskadt til Holsten, hvor han siden boede med sin familie til 1864 - uden at søge noget andet embede, levende af sine midler. Da han således frivillig 1850 havde forladt Husby, blev kateket i Hjørring, Aleth Hansen ${ }^{12}$ - senere provst og tilsidst kultusminister efter nogle måneders forløb kaldet til Husby. Skønt sprogforholdene, som ovenfor omtalt, væsentlig var de samme som i Hyrup var sindelaget vidt forskelligt - næsten alle tysksindede, og pastor Hansen havde der navnlig, efter at han tillige var bleven provst, en i mange henseender vanskelig stilling. I slutningen af 1858 blev Hansen hovedpræst ved det store sogn Grumtofte i Flensborg provsti. Af dem, der så søgte Husby, ønskede Hansen særlig mig til sin eftermand. Skønt jeg havde mine betænkeligheder dermed, måtte de vige for hensynet til den fulde berettigelse af sprogreskriptets indførelse der, hvor folkesproget overvejende var dansk, hvor der også var en kreds af dansksindede og af kirkelig sindede, der satte kirken højere end alt andet, varme missionærer - ( 3 unge mænd gik i Hansens og min embedstid til missionsskolen i Harmannsburg ${ }^{13}$ og senere til Afrika). -6 af hedningemissionen - og hensynet til min voksende familie og embedets større indtægter. Jeg søgte det da og blev kaldet dertil 14. januar 1859, og blev indsat Palmesøndag pá dansk og derfor kun med ringe deltagelse fra menighedens side. Imidlertid blev jeg støttet af skolens meget dygtige lærer og af de dansksindede, og årene gik uden store bryderier, og efterhånden vandt jeg om ikke sognets kjærlighed så dog dets agtelse, så jeg dog ikke kom til at fortryde, at jeg havde forladt det mere venligsindede Hyrup.

Så kom november 1863 det sorgens budskab: „Frederik d. 7de død«; for de fleste af os præster stod det som en afgjort sag, at dermed var krigen uundgåelig. I de følgende måneder rustedes der, flere og flere tropper droges over til Slesvig, og i december fik vi indkvartering af Randers dragoner; 

gavlen, hvorfra der var udsigt ned til byen; jeg studsede, da jeg kom derop og så vejen fuld af soldater, gik derned; på vejen mødte jeg et par soldater, som jeg bad gå ind i præstegården; det slog mig, da jeg så deres forundrede ansigter over den uventede venlige tiltale, hastede videre, til jeg i den første gård i byen traf en officer, som jeg spurgte: "Hvorfra kommer De dog?" Svaret lød: "Fra Kappeln«; "altså Dannevirke forladt!«; "Ja« svarede han;»så kan vi inden aften få fjenderne at se? « - "Ja, « det er meget sandsynligt.“ Hvad indtryk det gjorde på mig, er let at forstå; imidlertid fik jeg en del officerer og soldater med til præstegården, hvor de efter evne blev beværtede. Meget taknemmelige og forfriskede marcherede de snart videre ad Flensborg til. I en urolig spænding tilbragtes den for- og eftermiddag. Henad aften kom min karl med heste og vogn til min store overraskelse tilbage - jeg havde forestillet mig dem tagen af fjenden. „Nå, Gud ske lov! Andreas, at jeg ser dig igen, hvor så du sidst fjenderne? « "I Sattrup “ ( $1 \frac{1}{2} / 2$ mil fra Husby) svarede han. "Var det preussere eller østerrigere? " "Østerrigere" lød svaret; det lettede mit hjerte, da det havde været dagens ønske og bøn, at de første fjender, jeg skulle stå ansigt til ansigt med, dog måtte blive østerrigere.

Sondag morgen d. 7. endnu ingen! Da kirketiden nærmede sig, og degnen ikke, som han plejede, kom at følges med mig, sendte jeg bud til ham med forespørgsel: »hvorfor han ikke kom? « Beskeden lød: „Om jeg dog ikke vidste, at hele sognet var oversvømmet af østerrigere « - og i det samme øjeblik strømmede de ind igården! Det var et gribende øjeblik, men med den styrke og mod, som Gud giver dem, der slår deres lid til ham, tog jeg mod den indtrædende chef for 9' Jægerbataillon, oberst Schwab - køligt og formelt; næppe indkommen i stuen trækker han sit militærkort over Slesvig (det samme kort, som de danske officerer - og jeg også havde) op af lommen og siger til mig: "Vil De behage for indkvarteringens skyld at vise mig navnene på byerne i sognet." "Her er koldt, men i værelset ved siden af er der varme, vil obersten ikke træde derind . Han åbner døren, varmen slår ham imøde, og han udbryder: "Ah, hvor gør det godt! Når man har bivuakeret 5 dage og nætter under åben himmel -, kan De tro, man skønner på at komme ind, var det kun et hundehul og - her i en stor sal med varme! « Synlig formildet, oplystes han så om byen. Efter endt konference skulle jeg ud i gården at tale med min karl; idet jeg åbner døren, står en menig i stalddøren lige overfor, der, idet han ser mig, udbryder: "Verfluchter Däne“ og hæver truende hånden - det anføres kun, fordi det var det første og sidste ukvemsord af en østerrigers mund, som alle opførte sig meget vel med undtagelse af, at de stjal nogle høns. Foruden obersten fik jeg samme dag en captajn Kittel, adjudant friherre Reichtenberg, en nobel person og en læge, samt 26 mand menige soldater $\mathrm{i}$ indkvartering. Lægen var en ungarer, han kom efter de andre 
officerer; da vi mødtes, trådte han hen til mig, greb min hånd og sagde varmt: "Ja, hr. pastor, tro ikke, at vi kommer her af lyst, nej, nej, kun på kejserens befaling.« Nå, den indkvarteringsdag, var dog tålelig og gik vel til ende. Næste dag, mandag $d$. 8. februar kom der en indkvartering til på c. 70 mand altså havde jeg i det hele c. 100 mand; det var også østerrigere og hørte til samme regiment. Der blev strax en meget levende, højrøstet tale, hvoraf jeg kun kunne opfatte, at der havde været en blodig træfning med de danske, hvis tapperhed pristes $\mathrm{i}$ høje toner: "De stode fast som en mur." På et sted havde de set flere østerrigske officerer ligge døde, mange andre var faldne og sårede. Jeg havde ingen anelse om, hvor denne kamp havde stået, og fik det først at vide, da de afmarcherede den følgende onsdag; da kom ungareren hen til mig, og sagde mig, at det var ved Sankelmark - berømmelig ihukommelse! De ankomne soldater var $i$ høj grad forkomne og forsultne; min hustru stod $i$ køkkenet med et stort stykke flæskeside; så hurtigt som hun kunne skære skiver af, greb de som hungrige ulve stykkerne og slugte flæsket råt! De opførte sig iøvrigt upåklageligt; dog blev min kone advaret imod at lade sølvtøj komme til syne. "Det kløer deres fingre efter, “ føjede deres kaptajn til!

Tirsdag d. 9. kom naturalier til gården, så vi slap for at proviantere den masse! Om eftermiddagen samme dag oprandt de varste timer jeg har oplevet: Jeg stod ude i køkkenet for efter anmodning at forklare soldaterne, der stod i tætte klynger om mig, værdien af de mange forskellige mønter, der var i omløb, i forhold til vore danske penge; da banker en hảnd på skulderen af mig, og jeg ser en mig ganske ubekendt person, omgivet af 7 af sognets mest tysksindede mænd, og forlanger en samtale med mig. Da vi kom ind $\mathrm{i}$ dagligstuen, affordrede den ubekendte mig noglen til prastearkivet, hvor kirkens embedsbøger og dens øvrige dokumenter opbevaredes; jeg forstod strax betydningen af denne fordring, at de ville afsætte mig som præst og svarede strax bestemt: "Nej, på ingen måde; “ der udviklede sig da en lang ordstrid mellem den ubekendte og mig, stedse heftigere og heftigere, medens han som et rasende menneske foer op og ned af gulvet; jeg fastholdt med standhaftighed min vægring; lod ham vide, at lige så lidt som de havde indsat mig til præst, kunne de afsætte mig; han beråbte sig på magten, de havde, truede mig med, at det kunne gå mig, som det var gået andre embedsmænd f. eks. Blauenfeldt, ${ }^{16}$ som de havde sat på en kærre og ført bort; alle trusler hjalp ikke; med stor indre ro i sjælen afviste jeg alle hans forsøg på, som han udtrykte sig, på at gøre mig mør ("er wird bald mürbe werden»); det havde kun den modsatte virkning på mig og gjorde mig kun stærkere og modigere. Endelig da hans kompagnoner begyndte at indse, at jeg blev ubevægelig fast og de lidt urolige - foer han rasende ind pá mig og greb mig $i$ brystet. "Ja," udbrød jeg: " 8 mod 1 har vel overmagten og de kan overmande mig, men De, 
Peder Nissen og De, Frands Frandsen, De kan ikke stå og se på, at der sker Deres præst overlast.“ Med en mund udbrød de: "Nej, hr. pastor - det har aldrig været vor mening eller hensigt. « Så slap den ubekendte mig, jeg bad dem derpå at behage at gå deres vej. Den ubekendte begyndte forfra med sin fordring og holdt andre en stund tilbage; jeg sagde dem da, at når de endnu ikke ville gå, var der intet andet for mig at gøre end at tye til den østerrigske oberst; jeg gik da ind til ham, kun fulgt af den ubekendte. Obersten forstod ikke strax, hvad fordringen og udleveringen af nøglen til arkivet skulle betyde, men da det blev ham klart, vågnede hans retfærdighedsfølelse. - Så tog den ubekendte ordet og lagde obersten på hjerte, "at han havde været slesvig-holstensk officer, der havde für die heilige Sache des Vaterlandes geblutet, “ foreholdt ham "at jeg, som de andre danske embedsmænd var en spion “ (hvorpå jeg rolig appellerede til oberstens egen erfaring, da jeg ikke i de dage havde været udenfor min dør) og kom tilsidst med den infame insinuation, at kirkens obligationer opbevaredes $\mathrm{i}$ arkiv-skabet, hvortil jeg svarede, at den insinuation var skamløs, da han vel vidste, at obligationerne var noterede som kirkens ejendom - altså værdiløse i mine hænder. Oberst Schwalb havde nu hørt nok, og han bød ham nu gå bort, idet han tilføjede, "at han ikke tillod yderligere angreb på mig; havde menigheden noget at besvære sig over, kunne den henvende sig til den regeringskommission, der var indsat i Flensborg, den ville nok ordne sagerne. « Så måtte fyren flov stikke af; forst dagen efter fik jeg at vide, at han var søn af den omtalte degn Hansen, ${ }^{17}$ hvorved jeg fik lys over det hele optrin; blandt de 8 var også Hansens svigersøn Peder Jensen, ${ }^{18}$ en af de værste i hele Angeln som medlem af den slesvigske stænderforsamling, ivrig agitator i sprogsagen, hader af danskheden. Selvfølgelig føltes mit sind efter deres afvisning og bortgang lettet $i$ høj grad; jeg havde af denne oplevelse kraftig erfaret sandheden af det gode, gamle ord: "Hold dig til Gud $\mathrm{i}$ bøn og tro - det giver hjertet fred og ro" - thi den kraft og frimodighed, fred og ro, jeg følte under dette optrin og dets farer, stammede her ovenfra, hvorfor vi husets folk efter dets udgang også i forening frembar vor taksigelse til Gud, som så nådig havde holdt sin hånd over mig og friet mig ud af faren og gjort udgangen god, hvortil oberstens loyale, rolige holdning også havde stærkt bidraget; havde det været preussere, jeg havde haft $\mathrm{i}$ huset, er det meget tvivlsomt, om jeg havde fundet nogen beskyttelse, og hvad udfald sagen havde taget. Efter sigende vakte dette optrin et stærkt røre i sognet - at de dansksindede næste dag søgte oplysning om det passerede, kunne jeg vel vente og fandt hos dem varm deltagelse og fordømmelse af tyskernes færd, men selv blandt de tysksindede kom et par retsindige og bevidnede mig deres misbilligelse og beklagelse af det skete; også den omtalte Peder Nissen, min nabo, mødte i høj grad flov og benauet 
for at gøre undskyldning for sin deltagelse; det kostede mig stor overvindelse at se ham, som jeg ellers stod på venskabelig fod med; da jeg foreholdt ham, at jeg havde haft bedre tanker om ham - hans undskyldning var, at han kun var gå et med, fordi de andre havde tvunget ham dertil og ville have ham med, fordi han var kirkeværge, kunne jeg ikke holde svaret tilbage: " $\AA$ ! det viser kun, at De ingen mand er, men en fejg usling! ‘ Yderst skamfuld og nedslået forlod han mig med sin onde samvittighed. Samme dag - tirsdag d. 9. februar om middagen blev der mig meldt ny indkvartering; da jeg kom ud stod der 8 menige preussere for mig, der, da de så mig, sloge kolberne af geværerne i stenbroen og råbte brøsigt: "Hier sollen wir Preussen einquartiert und verpflegt werden." »Nå, det skal de, « var mit svar. »Ja, forplejning skal de få, kvarteret må de selv søge, her er allerede 100 østerrigere." De fandt ikke andet end huggehuset, et rum i den store kornlade, hvor østerrigerne lå, det rømmede de for redskaber, der stod, og slæbte halm derind. Da pigen var færdig, ville hun dække bordet til dem i folkestuen, der var fuld af østerrigere; de ville ikke give preusserne plads, men råbte: "Nej, nej! her kommer ingen preussere ind. « - $-\mathrm{Ja}$, hvor skal jeg da dække bord? « "In der Küche oder sonst wo, hier aber nicht« var svaret. - Altså dækkede hun på et bord i køkkenet og preusserne kom til sæde. Maden smagte dem næppe, den fik en bitter bismag; thi næppe var preusserne bænkede, før østerrigerne fra folkestuen strømmede ud og ind igennem køkkenet og uden ord, men med dyb foragt så ned på preusserne - rigtig ugleså dem.

Det var naturligvis til stor moro for os at se dette tegn på broderligt venskab mellem østerrigerne og preusserne, og det var ikke det eneste. Næste dag - onsdag d. 10. afmarcherede preusserne først og senere de 100 østerriger. - Fra deres ophold må jeg dog endnu melde, at friherre v. Richtenberg en dag, han vaskede sig, havde taget et par fingerringe af og lagt dem i vandfadet; oppasseren kastede vandet med dem ud i gården; der lå høj sne og trods ivrig eftersøgen lykkedes det ikke at finde ringene; ved afmarcheringen lovede jeg ham at sende ham dem, hvis de skulde findes. Det skete en dag i slutningen af februar. Da sneen var optøet, kom barnepigen ind med dem, jublende over sit fund. Jeg sendte dem da til herredsfogden i Flensborg til videre foranstaltning, og få dage efter fik jeg da et meget taknemmeligt brev fra Richtenberg fra Sommersted i Nordslesvig, hvor bataillonen lå, indeholdende 6 preussiske dalere til pigen i findeløn, hvorved hun naturligvis blev meget glad. I sit brev var Richtenberg naiv nok til at udtale sin beredvillighed til ved lejlighed at yde mig gentjeneste og udtale det håb, at han mundtlig kunne komme til at tolke mig sin taknemmelighed. Jeg fik ham ikke at se, og ved ikke, om han kom levende tilbage. -

Næppe var de 100 østerrigere dragen bort, førend der meldtes ny 
indkvartering, atter østerrigere, dog denne gang kun 3 officerer og c. 20 mand. Officererne meget flinke, med hvem jeg fint kunne tale om forholdene; jeg havde særlig min tilfredsstillelse ved at vise dem pastor Simonsens manuskript om sprogforholdene, (når jeg ville vise preusserne det, ville ingen af dem se det) som de forestillede sig ganske anderledes, end de virkelig var.

I mørkningen hører jeg en dump rullen i gården som af kanoner; jeg kommer ud og ser preussisk artilleri for mig og modtages af en officer med de ord: "Hier bekommen Sie Einquartierung, Hr. Pastor; die ist Ihnen wohl nicht angenehm," hvortil jeg koldt svarede: "Nein, gewiss nicht." Han forlangte da anvisning på plads til hestene, $» j a$, stalden er fuld af østerrigeres heste. " Svaret lød: "Der skal skaffes plads til vore heste. " Jeg måtte da - min karl var ikke tilstede - selv åbne kostalden, hvor den ene halvdel var tom, uden spilbomme eller krybber; han kommanderede hestene ind også på fodergangen og gav soldaterne ordre til at sørge for havre. De søgte strax til kornloftet - og tog havren, som de kastede lơs på gulvet til hestene. Jeg gik da ind $i$ huset efterfulgt af officeren, der står min karl Andreas, en ægte dansk Angelbo, og ham byder han at skaffe flere lygter. Andreas svarer ganske studs: "Hvad fanden! hvormange lygter tror De, at man har i et hus? Er 2 ikke nok! « Jeg ventede, at han vilde få en lussing eller af klingen, men mærkeligt nok officeren sagde ikke et ord - og Andreas så polisk på mig. Da vi kom ind $i$ spisestuen, det første værelse, hvorfra der var døre til min stue (allerede taget $i$ beslag af en læge), dagligstue og havestue, forlanger officeren, at jeg skal anvise ham særskilt værelse, hvortil han, som Colonneführer havde ret. jeg indvendte, at de østerrigske officerer disponerede alene over 3 værelser havestuen og 2 gæstekamre, at jeg nu så, at hans collega lagen havde installeret sig i mit værelse (det havde han uden videre, medens jeg var ude $i$ gården bemægtiget sig), vi havde kun dagligstue og sovekammer tilbage for mand, kone, 6 børn og lærerinde. Han vedblev hovent, at han ville have sit værelse for sig selv, og jeg var åbenhjertig nok til at bekende, at der var et værelse på loftet, som lærerinden beboede, som jeg ikke anslog, at han vilde berøve hende; han forlangte da at se det - og jeg måtte da harmfuld vise ham det. Da han så det, erklærede han straks: "Her vil jeg blive, es gefält mir ganz gut.." Snart efter forlangtes der aftensmad, som indtoges sammen med de østerrigske officerer til liden glæde for begge parter.

$\mathrm{Vi}$, hele familien, var altså indskrænkede til dagligstuen og sovekammeret. Om natten hører vi, at en tramper op ad trappen til Colonneführeren - og min kone og jeg havde straks samme tanke og ønske: Gid det må være ordre til preusserne at drage videre. Og det var virkelig så. Jeg blev liggende længe, idet jeg ikke ønskede at se dem for mine øjne. Det varede dog for længe, jeg stod op, og da jeg sidder og drikker min the, kommer en af officerene ind og 
spørger: Hvad de havde at betale for de 3 kopper the, de havde fået om morgenen (den varme aftensmad om aftenen, vinen og logi talte han ikke om). "Nichts," svarede jeg, "jeg holder ikke hotel." Der opstod da et mundhuggeri, hvori jeg blandt andet sagde ham, at da i denne tid så meget andet gik "verloren«, kunne jeg også tåle de 3 kopper the. Han vedblev at påstå, at dem ville han betale. Jeg hviskede da til min kone: Sig du dens værdi. Hun nævnede da nogle skillinger, dem smed han på klaveret - og afsted med ham - og glade var vi! -

Næppe var han ude af døren, før der atter bankes på, en oppasser træder ind, han skulde hilse fra Colonneführeren og spørge, om jeg ville sælge min hund, der stod lænket i gården. "Nej, nej, ikke for nogen pris“ - han afsted! de marcherede da afsted - dog uden hunden, som jeg antog, at de vakre fyre havde taget med sig.

(Denne hund, der var alles glæde, var en meget smuk sort, langhåret med brune pletter ved øjnene og på poterne; den var bleven lænket, fordi den strejfede om på markerne, dens hus stod under en mægtig lind, lige ud for indkørslen og var meget vagtsom; men fra det øjeblik, vi fik indkvartering, lukkede den ikke sin mund op. Da vi flyttede fra Husby, fik jeg en bonde indtil videre at tage den $\mathrm{i}$ kost. Under våbenhvilen, da jeg var bleven præst $\mathrm{i}$ Føns, kom den med 2 køer, 2 bønder havde taget til sig, og bohavet velbeholden til Middelfart - hvilken glæde, da den så mig der! Jeg tog den straks til præstegården, hvorfra den gjorde - ofte uden følgeskab - sine morgenbesøg på Rud, da moder med børn boede der. Den henlevede sine dage i Føns, sluttede der inderligt venskab med vor gase, især når gåsen rugede; (gasen lå inde $\mathrm{i}$ hundehuset, de karesserede gensidig hinanden og var os alle til stor fornøjelse. En middag efter års forløb så vi dem begge, da vi gik til bords - stå sammen uden for hundehuset, da vi rejste os fra bordet studsede vi ved at se hunden ligge så underligt udstrakt - den var pludselig død til sorg for gasen og os alle. Jeg fik dens skind til fodtæppe og brugte det indtil hårene var afslidte. Den hed med rette "Bon coeur « og mindes endnu så mange år efter hver gang, jeg ser en hund, der ligner den.)

Glæden over deres af march var desværre kun kort. Næppe en time derefter overraskedes jeg højst ubehageligt ved den melding, at de bortdragne preussere på vandringen fra os til Munkbrarup havde fået contraordre: De skulle gå tilbage igen til Husby. Nå, det bliver vel en drøj historie! Jeg havde den dag netop uopsættelige skriverier og ville højst nødig afgive min stue til de lømler, jeg bad derfor straks den østerrigske chef, om han ville tillade, at de tilbagevendende preussere delte opholdsværelse - havestuen - med dem om dagen; jeg ville da så vidt muligt se at sørge for preusserne for nattekvarter. Han indvilligede deri, jeg satte mig da atter til skrivebordet og oppebiede 
preussernes tilbagekomst; lod ikke længe vente på sig -inden jeg vidste af det, at de var komne tilbage, lukkedes døren til min stue op, og der stod oppasseren med kufferten på nakken og lægen. Jeg søgte at afværge deres indtrængen ved at meddele dem den med østerrigerne trufne aftale om fælles opholdsværelse - men uden virkning: „Hr. Pastor, wir wollen uns selbst einquartieren, " og dermed beordrede lægen oppasseren til at sætte kufferten i min stue. Nødtvungen tog jeg da min mappe og skrivetøjet og tyede ind $i$ dagligstuen. Da jeg havde fået sæde, hører jeg kort efter en mistænkelig, aparte banken på mit skrivebord, der stod ved vaggen, der stødte op til dagligstuen. Jeg foer da op og ind i min stue for at se, hvad der er på færde og se! på skrivebordet, der var ganske nyt, lå store skiver råt kød, der bearbejdes til bøf! "Nå, " udbrød jeg, "det finder de passende, måske vil de også stege kødet i kakkelovnen? Det er der plads til i køkkenet.«-Med hånlig mine svaredes der mig: "Aa, wir wollen uns selbst arrangieren.“ "Ja, så!« dermed tog jeg nogle papirer og ville gå, men standsedes af den anden preussiske officer, der begyndte at udbrede sig over de for de danske embedsmænd vanskelige forhold og de dem truende farer fra de omstrejfende bander, men føjede nedladende til: "So lange wir hier sind, können Sie aber ruhig sein." - Jeg kunde ikke dy mig for at svare: "Jeg ventede ikke at skulle komme til at trænge til Deres beskyttelse." "Ja, "svarede han, "man kan dog ikke vide, hvad der kan ske, og i hvert fald ville jeg ikke kunne blive i mit embede." - "Nej. Det har vi længe kunnet sige os selv, at blev Dannevirke forladt, var vi dømte til at opgive vore embeder, men det var vor trøst, at vi havde en konge og regering, der ikke ville lade sine embedsmænd i stikken og folket ikke heller. Nord for Flensborg boede der kun danske « - $D \mathrm{Da}$ irren Sie sich." - "Nej," svarede jeg, "da irre ich mich nicht; det vil de nok komme til at erfare, når de kommer Flensborg forbi.« Dermed forlod jeg dem og gik harmfuld ind i dagligstuen. -

Opad dagen afmarcherede østerrigerne til vor bedrøvelse - de var perler i sammenligning med preusserne - men også dem slap vi inden samme dags aften - til stor lettelse og glæde. - Dette passerede torsdag d. 12. februar; fredag den 13. februar havde vi ingen indkvartering i Husby. Degnen Samuelsen, ${ }^{19}$ der ikke var uden frygt for, hvad der kunne ske, når vi var uden regulært militær, rejste da til Flensborg i den tanke at udvirke, at vi fik sådant; han kom først hjem kort før tiden til gudstjenesten om søndagen og fortalte $\mathrm{da}$, at hans bestræbelse i den retning havde været frugtesløs, derimod havde han oplevet noget ganske andet og for mig betydningsfuldere. Da han nemlig om lørdagen opholdt sig på den gæstgivergård, hvor husbyerne i reglen tog ind, var der kommen en velklædt herre ind og havde spurgt, om der var nogen fra Husby tilstede; da han så havde givet sig til kende som degn der, udbrød 


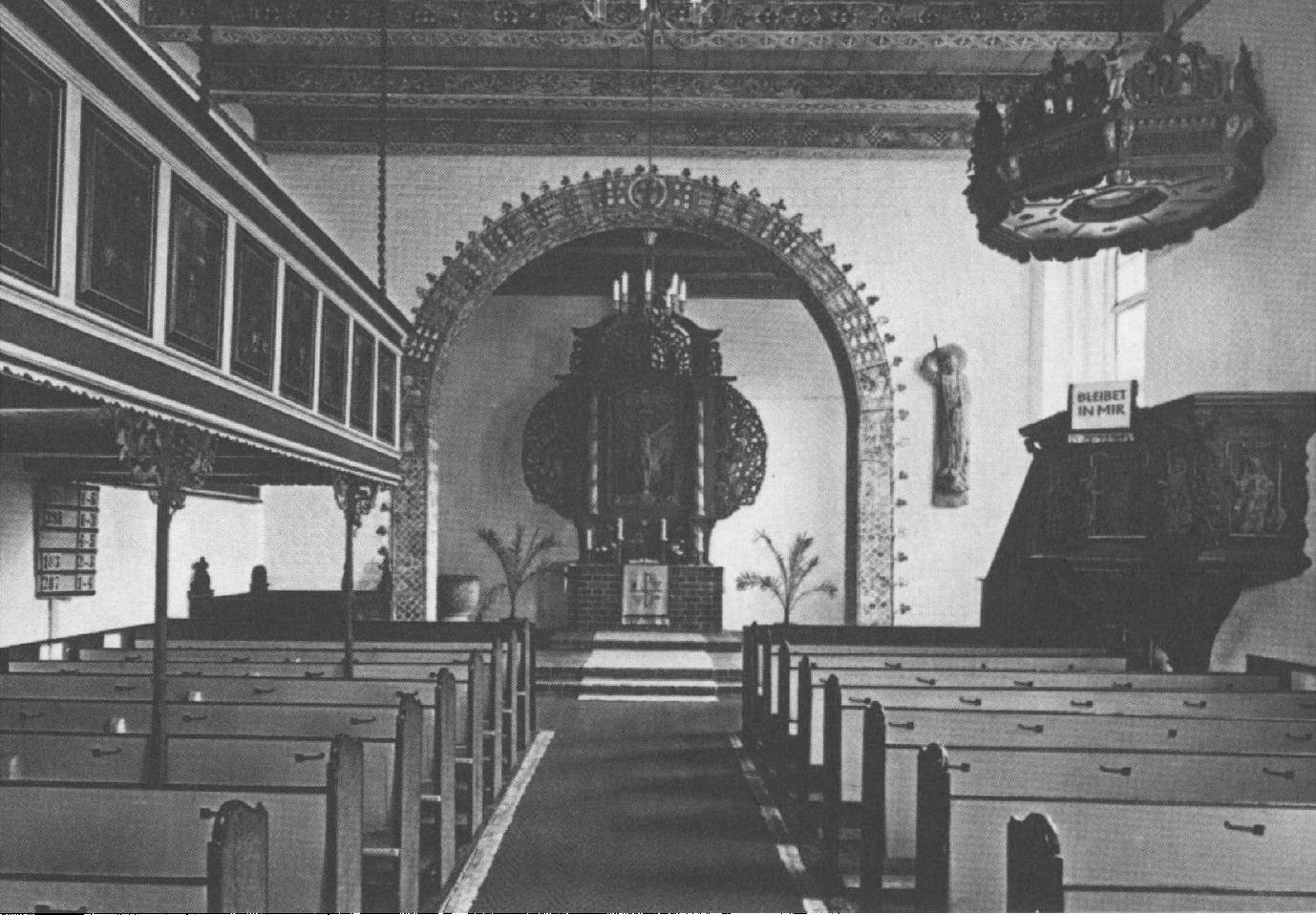

Nyere billede af Husby kirke. (Postkort: Gerd Remmer, Flensborg).

den ubekendte: "Det var jo såre heldigt, at han netop traf ham.« "Deres præst er jo »flygtet« og jeg er opfordret til at tage derud og prædike $\mathrm{i}$ hans sted." "Nej, “ forsikrede Samuelsen "vor præst er på sin plads og kendte han mig ret, var der ikke tale om, at han forlod den. « Den fremmede person påstod ikke desto mindre, at jeg var "davon gelaufen ", det vidste han fra flere sider (det var nemlig en almindelig forestilling hos slesvig-holstenerne, at når preusserne havde taget Dannevirke, da så de i ånden os præster alle på flugten med de blå gendarmer! Det havde de jo set flere af deres tidligere præster gøre altså sluttede de, måtte vi gøre ligeså. Samuelsen blev ved sit og han med sit. Tiden skulle vise, hvem der havde ret. -

Jeg kom altså rigtigt nok til kirke; da jeg kom på prædikestolen, faldt mit øje snart på en fremmed, velklædt herre, der havde taget plads tæt ved indgangen; jeg forrettede tjenesten som sædvanlig - men med den forvisning, at den ubekendte måtte være min selvbestaltede eftermand. Da tjenesten var forbi, ser jeg Samuelsen i ivrig samtale med ham; de skiltes ad, før jeg kom til udgangen; da jeg så spørger Samuelsen: "Er det min eftermand? «Nej, " svarer han: "men det er min, i al fald $i$ håbet. " Han fortalte mig så, at det var en mand, han kendte; de havde endog været på seminariet sammen i Skårup, og nu havde han haft den frækhed at fremstille sig som aspirant til Samuelsens embede! 
Men hvad var der bleven af min eftermand? Dagen efter fik jeg at vide, at han virkelig havde været i Husby, men måtte nøjes med at prædike i Nicolai Gondesens hus. En af de værste "Wühlere“. Samme mand sagdes at hedde Neergaard, ${ }^{20}$ at være præst i Holsten og nu på jagt efter Husby. Han skal forresten senere være bleven præst i Nordslesvig, hvor han dog efter et par år skal have gjort sig umulig, - dette ved jeg dog kun »von Hören sagen«. - Men hans optræden med Samuelsen i Flensborg og senere i Husby lader os dog skimte bag kulisserne, hvorledes man har betragtet det som en afgjort sag, at jeg ikke kunne have modstået anløbet på mig hin aften, men måtte have taget flugten - at de andre præster havde fulgt efter og at der således var embeder at fiske. Det gik dog ikke efter deres tanker, i det øjeblik vi blev i Flensborg provsti eller på vore pladser, indtil vi blev afsatte af voldsregeringen - hvad først skete flere uger efter.

De uger var i høj grad pinagtige, i den [tid] blev kirken lukket enkelte steder og præster blev nægtet at holde tjeneste; der blev også gjort forsøg i Husby, idet der en søndag morgen kom bud fra degnen, at kirkeværgen, der opbevarede kirkenøglen og var den omtalte Peder Nissen - ikke ville udlevere den; da jeg imidlertid sendte bud til ham og truede ham med, at hvis jeg ikke fik den øjeblikkelig, ville melde det til amtmanden og kræve ham til regnskab - faldt han dog til føje og udleverede den til mig. Jeg holdt da også hver onsdag og søndag gudstjeneste, udelukkende på tysk, som straks blev os befalet. Det var selvfølgelig en svær gang, da jeg måtte gå dertil med den alvorlige tanke og vemodige følelse: Mon det nu er sidste gang?

En faste-onsdag har indprentet sig dybt i mit hjerte; dagen forud kom der melding fra Samuelsen, at der havde indkvarteret sig hos en bonde i byen en officer i østerrigsk uniform og en menig dragon. - Bonden, der ikke var af de værste, lod Samuelsen vide, at officeren teede sig som et rasende menneske, der foer op og ned af gulvet og hvert øjeblik udstødte trusler mod præst og degn, at nu gik han hen og ville skyde snart den ene og snart den anden; i sin vånde lod Samuelsen mig opsøge, hvad vi skulle gøre. Jeg havde intet andet råd at give ham og mig selv end: Give sig Gud i vold, henfly under hans almagts-vinger og lade Gud råde! Jeg blev i hvert fald i min rede. Der kom atter bud fra Samuelsen, at det var en ren desperat mand - om det dogikke var bedst, at vi søgte at redde skindet og flye. Han fik hver gang samme eller lignende svar med henvisning til ham velbekendte skriftord: "Der krummes ikke et hår på vort hoved“, "der falder ikke en spurv til jorden uden eders himmelske faders vilje “ - og bøn til ham, at han dog ikke måtte glemme den. I disse ord følte jeg mig rolig og tryg og tænkte ikke et øjeblik på flugt. Langt om længe ud på aftenen kom der så bud fra Samuelsen, at bonden havde meldt ham, at nu var galningen gået til ro - så vi vist også kunne gøre det 
samme. - Da det var på tide, søgte jeg sengen, sov meget godt og roligt ovenpå den historie. Da min kone og jeg næste dag gik til kirke - et kvarters gang fra præstegården - var der efter en faste-onsdag at regne, en usædvanlig talrig forsamling; jeg fristedes til den tanke, at der iblandt vistnok var flere, som var indviede $i$ hin officers planer. Alt gik i sin sædvanlige orden næsten til tjenestens ende; men da jeg står på prædikestolen i slutningsbønnen, studser vi alle ved at høre en røst af en person, som under jamren og hylen nærmer sig mere og mere op til kirken. Jeg standser i talen, og de ved indgangsdøren nærmest siddende løber ud - der høres høj tale derude, snart bliver der stille og de, der. var gået ud, kom ind igen - og jeg sluttede prædikenen. Da tjenesten var endt $\mathrm{og}$ jeg kom ud af kirken og fik forkla ring på det passerede, fortaltes der, at den omtalte galning med dragonen var kommen ned til et hus, der lå nedenfor kirkebakken og beboedes af en bekendt dansksindet mand, som galningen befalede skulle komme ud; da han træder ud af sin dør, befaler galningen dragonen, at han skal skyde "den spion". - Dragonen vægrede sig derved, og officeren drager da selv sin sabel og fugtler ${ }^{21}$ manden igennem; da er det, at datteren i sin angst og fortvivlelse haster hylende og klagende op til kirken. Ved at høre dette gribes min kone, som ellers med sin hjertefred og store sjalsstyrke var mig til så kraftig en støtte, et øjeblik af angst og udbryder til mig: " $\AA$ Gud! nu kan du tro, at han er vejen ned til præstegården, og at turen kommer til dig." Jeg beroligede hende - og vi kom uden ulempe hjem - og der var ingen, der modtog os med sværd eller skud kun friske og fornøjede barneansigter. Jeg underrettede selvfølgelig herredsfogden om disse optrin, og nogle dage efter kom han ud til mig og fortalte mig resultatet af hans efterforskninger. Den forestillede østerrigske officer havde vist sig at være en slesvig-holstener, der på en ikke opklaret måde havde fảet fat $i$ en officer-uniform og en dragon, og i denne forklædning havde han - vist til sin egen store fornøjelse - gjort en razzia ud i Angeln, hjemsøgt blandt andre dansksindede familier, godsejer Hagemann på Udmark (Ohrfeld) i Gelting $\operatorname{sogn}^{21}$ for at indjage dem skræk og tilsidst spillet den omtalte rolle $i$ Husby - dog uden stort udbytte.

Efter den første uges stærke indkvartering (7.-14. febr.) og de beskrevne hændelser, gik de følgende roligere af; der er egentlig kun 2 indkvarteringer, der er værd at omtale; den ene bragte blandt andre en dyrlæge, en forresten rå og væmmelig karl, men dog til min overraskelse ikke uden sund sans og retfærdighedsfølelse. Han var hos os på en dag, hvor kirkevisitatoriet (๖: amtmand og præst) havde meldt deres komme til Husby skole for at undersøge, om degnen Samuelsen kunne undervise på tysk; jeg var også anmodet om at give møde i skolen - men tillod mig at udeblive. Efter mødet hvor dyrlægen havde indfundet sig, lod han sig melde og bad om tilladelse til 


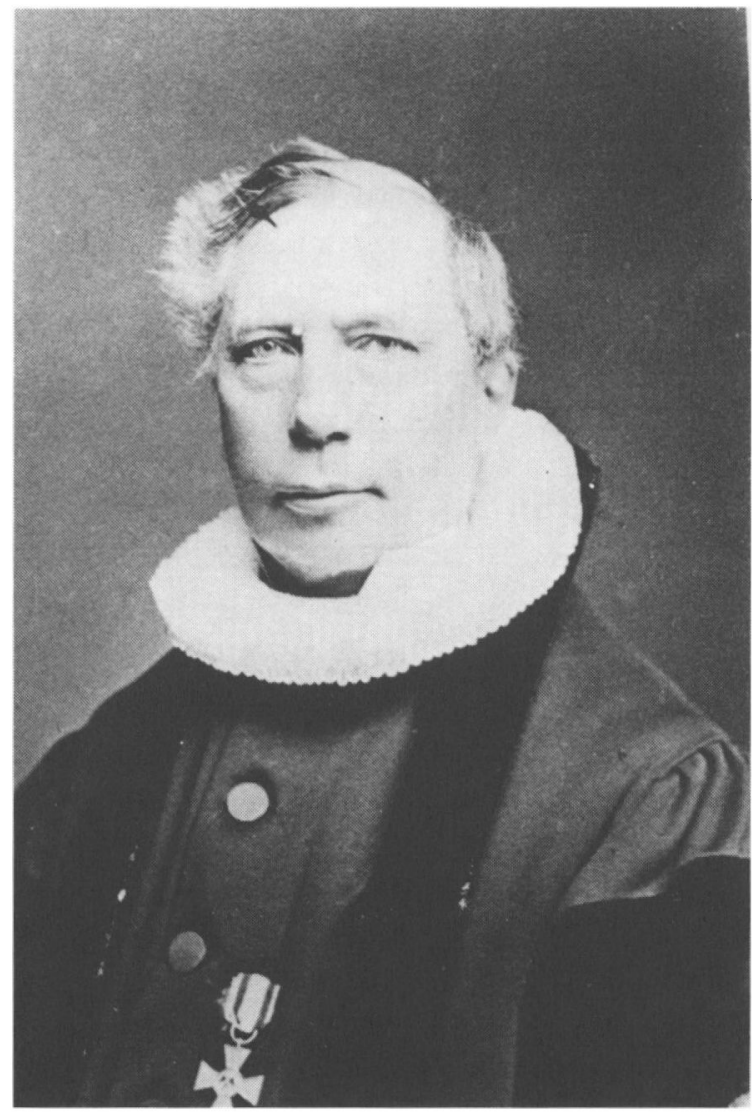

Provst Otto Nic. Henning Peters. (Dansk Centralbibliotek for Sydslesvig).

at komme ind til mig, han havde noget at fortælle mig. Jeg lod ham rigtignok med uvilje komme ind til mig, han slængte sig i sofaen ved min side, dampende på en cigar, som i høj grad pinte mine dårlige øjne (jeg havde, som jeg senere fik at vide - den agyptiske øjensyge, rimeligvis smittet af østerrigerne, som led deraf) og begyndte sin fortælling. Da skolen var samlet, begyndte provsten Peters ${ }^{23}$ (han havde ageret loyal under den danske regering og nu af fjenden var indsat til provst i stedet for Hansen - dyrlægen karakteriserede ham derfor med at kalde ham med rette: "dieser Mantelträger“ (en mand der bærer kappen på begge skuldre) - med at opfordre Samuelsen til at katekisere børnene på tysk; dermed var de snart færdige, "han gjorde sine sager ganske fortræffelig,“ erklærede dyrlægen. Derpå retter provsten - amtmanden mødte ikke - så de spørgsmål til de forsamlede, om de ellers havde noget at forebringe mod degnen, hvorpå en svarer, at han var 
dem til stor forargelse med sine danske sympatier, og som bevis henpeger han så på, at der stod 2 buster - et Christusbillede og et af Frederik d. 7., et på hver side af katedret, og de billeder havde degnen fået børnene til at anskaffe ved at skillinge sammen - og som anden klage fremføres, "at degnen overhovedet ikke var dygtig til at forestå så stor en skole.« Med stærk patos udbryder så dyrlægen: "Har man nu i sine dage hørt mage til klager; det skal lægges en skolelærer til last, at han indprenter børnene ærefrygt og kærlighed til deres himmelske og jordiske konge - og han, en mand i sine bedste år, udmærket begavet, han er ikke "fähig" til at forestå så stor en skole, men den gamle, en olding på 80 år, taub og blind, dazu er ist aber fähig " (han sigtede med denne ironiske tilføjning til planen, at Samuelsen skulde afsættes og embedet betroes til den før omtalte Hansen, slesvig-holsteneren, der flygtede efter Isted-slaget og tog Simonsen med). "Ja, « sluttede dyrlægen "die Leute hier sind ja ganz und gar verrückt. « Så ledes måtte denne preusser i modsætning til alle dem, jeg ellers havde haft indkvarteret, dog give sandheden ære, og for denne hans udtalelse var jeg forsonet med den mig ellers så modbydelige tysker. Eftertiden gav ham ret i hans omdømme: Samuelsen blev kort efter mig virkelig afsat - og den gamle Hansen fik embedet igen - iøvrigt til liden glæde for ham så vel som for skolen. I denne forbindelse vil jeg fortælle en historie fra år tilbage til oplysning om skolens sande tilstand. På grund af den idelige agitation mod dansk i skolen og den tyske presses løgne om børnenes "Verdümmung “ (sic!) foretog Blixen-Finecke, ${ }^{24}$ mens han var minister for Slesvig, en lille rundrejse om i Angeln til forskellige skoler, han kom aldeles uventet også til Husby - en middag ruller der en stor åben vogn som de gamle dagvogne ind i præstegården med 2 personer på; jeg kendte ingen af dem; de springer i en fart af vognen og præsenterer sig som minister Blixen-Finecke og etatsråd Juhl, ${ }^{25}$ så vidt jeg ved den gang medlem af Flensborg appellationsret og skal leve endnu. - Deres ærinde var at aflægge besøg i skolen i Husby; jeg beklagede, at tidspunktet var mindre heldigt, da det var middag og børnene næppe samlede; vi gik strax derhen, og Samuelsen kaldte sammen de børn, som var tilstede, og prøven begyndte med dansk og tysk læsning, oversættelse fra det ene sprog til det andet, katekisation over lærebogen (Balslevs forklaring) - og alt gik fortræffeligt. Glanspunktet var dog overhøringen i Danmarks, især Slesvigs historie, som i den grad betog Juhl, der sad ved siden af mig på en skolebænk, entusiastisk udbrød: "Åh, det skulle Grundtvig have hørt." Ministeren udtalte sin glæde og tilfredshed med prøven, greb i lommen og rakte med varm tak skolelæreren sit cigarfuteral fuldt af de fineste cigarer, beklagende, at han ingen værdifuldere genstand havde ved hånden at give ham til minde om dagen. Efter et kort ophold i præstegå rden, hvor ministeren udfoldede sin indtagende persons elskværdighed, rejste de til Sørup skole, 
den 3die som den dag besøgtes. Bladene bragte kort efter referat af denne visitats til gendrivelse af tyskernes klage over børnenes "Verdümmung". -

Derefter hengik nogen tid, hvori vi havde ingen indkvartering; kun lå der $\mathrm{i}$ Husby en preussisk soldat til oppasser for en syg hest; det var hans daglige beskæftigelse at forsøge sig så vidt muligt at vise sig ubehagelig over for mig; til den ende red han op og ned ad vejen udenfor præstegården, pibende $i$ en flejte; ofte kom han med sit halløj ind i gården og gjorde en vending, var særlig glad, når han havde en skrivelse fra voldsregeringen at overbringe, kom så uden videre plumpende ind $\mathrm{i}$ stuen og kastede hånligt brevet på bordet, aflagde oftere aftenbesøg $\mathrm{i}$ min folkestue, hvorfra jeg havde vanskelighed med at fordrive ham, trak besøget ud over sengetid - og var mig daglig en plage.

Endelig henimod midten af marts meldte en dag en preussisk officer mod sædvane sig selv og andre til indkvartering. Jeg gik da i spændt forventning om min afskedigelse; nogle dage forinden havde vi præster i provstiet været tilsagte til at give møde hos provst Peters. Man skulle i voldsregeringens navn forelægge os det spørgsmål, om vi var villige (»innerlich bereit«) til at indføre tysk som udelukkende kirkesprog og skolesprog; det var jo et forlangende, som ingen af os på nogen måde kunne gå ind på, vi svarede da alle med en mund et bestemt "Nej! « Provst Peters betydede os, hvad vi vidste forud, at vort afslag ville have vor afskedigelse til følge. Jeg gik altså og ventede på den, da officeren meldte sig til indkvartering, hvorfor jeg måtte bede ham om at fritage os for, da jeg selvfølgelig ville rejse, så snart afskedigelsen var kommen. Han beklagede, at det stod ikke i hans magt at fritage mig; i samme øjeblik kom Carl ind i stuen, og officeren vender sig imod ham, hilser ham med de ord: "God dag, min lille dreng, « og derpå siger han til mig: „Der kan De høre, at jeg dog har lært lidt dansk .« Ved disse ytringer så vel som sin hele, ikke preussiske optræden, have han gjort et godt indtryk på mig - og det blev endnu meget bedre; ledsaget af bondefogden, en slesvig-holstener, gik han til degnen; efter at han der havde udført sit ærinde og samtalede med Samuelsen, udbryder han: "Hvad er bønderne her dog for nogle hallunker; de klager over det danske sprogs indførelse i kirke og skole, her er jo ikke en, der kan tale højtysk, de kan jo knapt forstå det! De klager over deres "Nothstand« og allevegne så man kun "Wohlstand" og de klager over den danske misregering, de vil få noget andet at føle: Ja. dieser Zedlitz (den preussiske regeringskommissær) han svinger allerede svøben (die Rüthe) over deres hoveder. " Det var jo sande, rene ord for pengene, den lød som liflig musik i Samuelsens øre og - i mine, da han fortalte mig det, - men som "grausame Salbe" $\mathrm{i}$ bondefogdens, der efter Samuelsens sigende, skælvede og formelig stod og rystede. Vi fik dog kun en lille indkvartering en enkelt dag. 
Endelig efter disse 6-7 pinagtige uger kom befrielsen; ${ }^{25 a}$ den 15 . marts fik jeg en husmand til at køre mig til Flensborg, (mine egne heste og karl var i krigskørsel). Da vi kom op på landevejen 4-500 alen fra præstegården, lå der en preussisk soldat lænet til grøftevolden; han gav tegn til os, jeg lod som jeg ikke så ham og hviskede til husmanden: "Kør bare videre, " men da soldaten greb geværet og truede os, standsede vi, og han satte sig op hos kusken og begyndte strax, idet han slog på "geværet" og vendte sig om imod mig, at lovprise deres "Hinternadelngewehr", og det skulle "die verfluchten Dänen“ snart komme til at smage. Vi kørte altså videre under følelsen af, at de tyskere vi mødte, alle som en, der boede ved vejen, tænkte i deres hjerter: Nå, nu skal den Husby præst nok i kachotten - hvad han dog ikke skulle! Soldaten stod dog af udenfor byen - og jeg gik strax til amtmandens bolig. Da jeg kom ind $i$ stueetagen, så den meget uryddelig ud: Døren til værelserne stod åbne og møblerne $\mathrm{i}$ uorden. På trappen op til kontoret møder jeg amtmanden (Wedell-Wedellsborg, ${ }^{26}$ nu i Frederiksborg) og udbryder: »Nå, hr. amtmand, De er nok færdig " og han svarer og "De med, Nissen; jeg har i dag fået Deres afskedigelse, den kan De få med." - Og glad blev jeg, og med lettet sind skyndte jeg mig at udføre de arinder, jeg havde, og ilede hjem og blev modtaget med glæde. Ordren lød på, at vi havde at rejse snarest muligt over Hamborg. De følgende dage var da fulde af travlhed; solgte hvad jeg kunne, køerne til spotpris, med undtagelse af 2, som snart skulle kælve, og som 2 bønder tog $\mathrm{i}$ kost, og som jeg senere under våbenhvilen med hunden fik til Føns; mine 2 nydelige små sorte heste solgte jeg en dag, karlen ikke var hjemme for $230 \mathrm{rdl}$. ( $5 \mathrm{rdl}$. mere end jeg havde givet for dem efter at have brugt dem $\mathrm{i} 12$ år) på den betingelse, at de ikke måtte skilles ad og at modtage $\mathrm{i}$ Flensborg, når jeg var færdig i Husby. Da karlen kom hjem, beklagede han, at han ikke havde været tilstede; han kendte køberen, det var en pranger, og han troede ikke, at han holdt sit ord, at de skulle blive sammen. Og han fik ret, som jeg senere skal fortælle. En del blev stående i præstegården under kirkeværgens varetægt for at sælges ved auktion, der også senere blev holdt mig kun til tab; hele udbyttet blev $200 \mathrm{rdl}$. Resten af bohavet blev ført til Flensborg og betroet til opbevaring hos den gastgiver, vi tog ind hos og som vågede med troskab over det, og onsdag d. 23. marts - dagen før skærtorsdag - forlod vi så med blandede følelser Husby og kom der aldrig mere; det har $\mathrm{i}$ alle de år været mig en umulighed at kunne gense det sted.

Da vi kom til Flensborg, var køberen af hestene i gæstgivergården, og da jeg havde fået betalingen, gik jeg ud i byen; noget efter mødte jeg min karl, Andreas, og med grædende tårer fortalte han mig: „Det gik som jeg tænkte. Hestene er allerede skilte ad, hver til sin side " og, sukkende føjede han til: "Bare jeg dog havde købt dem." "Du, Andreas, hvad brug havde du dog for 
dem? « " $\AA$, jeg kunne have tjent penge ved at køre i krigskørsel med dem. Nå, gjort gerning stod ikke til at ændre. Siden, da jeg så snart efter blev præst i Føns - var jeg nær ved at ønske, at jeg ikke havde solgt dem, men fået dem, som de 2 køer på foder hos en bonde. Efter krigen kom mange slesvigere til Fyen og tog tjeneste der, også flere til Føns sogn. - En skøn dag kommer der så en slesviger, der tjente i nærheden af præstegården til mig for at fortælle mig, at han havde tjent hos en bonde i et sogn, vesten for Husby - jeg husker nu ikke mere hvilket - som havde købt den ene af hestene - og det mærkelige, at hesten i de første dage ikke åd eller drak, men var så urolig på stalden, stod og vrinskede af længsel efter den anden, sveden haglede ned ad den, og først da den ikke længer kunne holde sulten og tørsten ud, måtte den give sig dertil. Jeg havde haft så mange prøver på deres indbyrdes kærlighed, kan jeg gærne kalde det - de sagdes forresten at være brødre - jeg red i de år af og til på dens mage, men aldrig uden at karlen var hjemme, den var ellers aldeles ustyrlig på stalden; længe efter, at jeg var reden ud af gården, kunne jeg høre dens trampen og vrinsken! Dens mage oplevede jeg også et lille eventyr med: Fra Hyrup red jeg en meget tåget eftermiddag ned at besøge provst Hansen, da i Husby, fast bestemt på at ride hjem, inden det blev mørkt; men som det går, de pressede på, at jeg skulle blive og drikke the, og jeg lod mig overtale. Da jeg var kommen på hesten, vaklede jeg i valget, om jeg skulle følge den almindelige kørevej eller ad en genvej - en markvej, som jeg havde benyttet, da jeg red derned. I tillid til hesten, og fordi genvejen var en del kortere, bestemte jeg mig for markvejen, skøndt det [var] meget mørkt. Jeg kom rigtigt ind på den, og hesten luntede af $\mathrm{i}$ en kort trav, men efterhånden sagtnede den farten, og noget efter mærkede jeg, at vi var på afvej; jeg stod af og gik ved siden af hesten for bedre at orientere mig og atter op. Hesten gik yderst forsigtig og dens langsomste skridtgang; kom snart på en vej og så en anden, frem og tilbage, ikke et lys at skimte, ikke en lyd at høre, ikke et hundeglam; da i halv fortvivlelse uden at vide retningen, drejer jeg af ind på en anden vej, i samme langsomme og forsigtige gang. Med et kommer der pludselig liv i hesten, og den begynder at trave - vi var da komne til et terræn, som den og ikke jeg kendte - til en mark, jeg havde ved Weseby, ${ }^{27}$ omtrent en fjerdingvej fra præstegården. Snart kunne jeg skimte en lille mig vel bekendt skovgruppe og lys i en gård; nu var jeg vis på, at vi havde sejret og i strygende fart gik det ad hjemmet til, hvor jeg var ventet med ængstelig længsel, jeg havde lært, at genvej var omvej og frygtede siden Gud endmere og fulgte landevejen.

$\mathrm{Nu}$ tilbage til Flensborg; der overnattede vi onsdag, og skærtorsdag morgen mødtes så vi med provst Hansen og Imanuel Barfods ${ }^{28}$ familie på banegården, hvor vi naturligvis var genstand for mange venliges og uvenliges 
blikke. Barfods og vi sad i samme kupe, Hansens ved siden af, og farten til Hamborg begyndte, og ved alle stationer havde vi folks opmærksomhed henvendt på os - overalt dog kun høflige - indtil vi nåede Rendsborg; der havde samlet sig en del bøller på stationen - det var netop årsdagen for oprørets udbrud den 24. marts, der blev sunget bekendte spotteviser over Hannemann, særlig ved Hansens kupé, og der fremstilledes et billede af ham, just ikke lysteligt at se til; han, som særlig var hadet af slesvig-holstenerne, sås hængende $i$ en galge; det var ikke ophyggeligt for nogen af os, mindst for ham! Imidlertid det blev ved disse tomme demonstrationer, vi slap under pibernes lyd derfra og kom uden nogensomhelst ulempe igennem Holsten til Hamborg og blev modtagen - alle 3 familier på samme hotel - med deltagende høflighed, lå der om natten. Opholdet var os just ikke billigt og næste morgen gik turen til Lybæk, hvor vi var det meste af dagen - langfredag og så på dampskib til København uden søsyge, til vi nåede Køge bugt, hvor der var almindelig ofring til Neptun. Vi fik husly hos svoger Thortsen, der husede os mod nogen billig godtgørelse til slutningen af april. -

Iøvrigt var stemningen i Københa vn ingenlunde fornøjelig, i reglen mødte man modløshed, forsagthed stundom endog nogen mistillid og utilfredshed mod de afsatte embedsmænd i stedet for, at vi havde håbet på opmuntring og trøst. Vi afsatte var åbenbart meget frejdigere og tillidsfuldere end københavnerne, tildels vel en følge af, at vi var komne ud af ornens kløer. Regeringen tilstod os en rejsegodtgørelse af $50 \mathrm{rdl}$. pr. familie (rejsen kostede mig dog 110 rdl.) og en månedlig godtgørelse efter vore embedsindtægter, for mig 168 rdl., som jeg kun nød i 2 måneder. Jeg længtes efter ny virksomhed, det var mig uudholdeligt at gå uge efter uge uden fast beskæftigelse. Medens jeg endnu var i Husby kom en dag et no. af Dagbladet mig i hænde og der stod, at embedet i Herredskirke og Lille Løitofte på Lolland var ledigt. Indtægten var ikke større, end at jeg mente at kunne søge det, skrev ansøgningen og fik den sendt til biskop Boesen i Flensborg, der antoges at kunne skaffe den ad skjulte veje til København; ankommen her, forhørte jeg i ministeriet, om det havde fået min ansøgning. Nej, men tilføjedes der: I betragtning af omstændighederne kan De endnu indgive den; nogle dage efter gik jeg igen op i ministeriet for at se listen på ansøgerne, møder Barfod, der også søgte det, i porten, og han siger: „Der er ingen udsigt til, at nogen af os kommer i betragtning, vi kan pakke sammen, der er flere ansøgere, der er ældre end vi, " hvortil jeg svarer: "Det var da også for meget at vente, at vi skulle kunne få det første, vi søgte; « er der intet andet embede ledigt? Jo, der står opslået Føns på Fyn, det ville han ikke søge; jeg gjorde det. Der gik uger hen, og jeg flyttede med familie til svoger Schütz på Fredensborg; der får jeg brev fra provst Hansen med forespørgsel, om jeg ville antage plads som 
hjælpepræst hos Steen i Rudkøbing. "Ja vel, men på betingelse af, at jeg måtte have 8 dage, inden jeg endelig bestemte mig." Jeg mente, at $i$ den tid kunne besættelsen af de 2 embeder, jeg søgte, ventes afgjort. Den 6 . maj søgte jeg adgang til kabinetssekretær Trap, som jeg kend te lidt fra Slesvig, træffer ham i hans private bolig og på min forespørgsel svarer han: "Kongen har netop nylig underskrevet 2 slesvigske præsters udnævnelse - den ene til Fyn, den anden til Lolland, men kom det og det klokkeslet op på mit kontor på Christianborg.“ -

Jeg mødte selvfølgelig på pletten og får da at vide, at Barfod er kaldet til Herredskirke og jeg til Føns. - Det jublede i mig og hjertensglad drog jeg til Fredensborg - og der blev glæde! Men der blev også glæde hos kollegaerne, der $\mathrm{i}$ vor hurtige kaldelse så et forvarsel om, at heller ikke deres ventetid skulle blive lang.

Imidlertid gik det ikke så hurtigt med de andres befordring - kun provst Karstensen ${ }^{29}$ blev i sommerens løb kaldet til Gjelsted. Om efteråret blev de andre præster $i$ nåde afskediget af kongen og satte på ventepenge. Jeg meldte mig strax til min tilkommende provst, Fønss ${ }^{30}$ i Middelfart og bad mig indsat, så snart han havde lejlighed; det skete allerede 1. søndag efter trinitatis. Modtagelsen i Føns var Gud ske lov, meget imødekommende og hjertelig. I præstegården var der dog sorg; et par dage, før jeg kom dertil, var en gift datter efter sin nedkomst død. I sognet var der indkvartering og desuden hjemme med kjæreste, en svigersøn med kone o.fl., så den lejlighed der tilbødes mig, indskrænkede sig til et meget lille værelse, der tilmed var mit sovekammer. Efter Dybbøls fald og endnu mere efter Als's tab droges jo større og større troppemasser til Fyen, så vi havde indkvartering lige til freden blev sluttet. Stemningen blandt de officerer, der lå i præstegården var for det meste forsagt og modløs; man ventede, at østerrigerne skulle forsøge overgangen til Fyen, netop på Fønsskov, en odde der fra Føns by strækker sig en mil ud i Lillebælt, og historien stadfæster jo også, at der foretoges forberedelser dertil. Medens det almindeligt var officerernes første spørgsmål, når de kom i indkvartering: "Hvor går retrætelinien" - og den så undersøgtes på kortet, kunne man dog høre enkelte modige soldater sige: "Ja, lad fjenderne kun komme, kan vi ikke forhindre dem adgang her eller slå dem tilbage - så er vi nogle fejge uslinger - hvor skulle der være et plet lettere at forsvare end denne smalle strimmel land? Var en landgang lykkedes, havde jeg siddet net $\mathrm{i}$ det. Vejen fra Fønsskov gik lige udenfor præstegården, og mit hele indbo, som jeg under våbenhvilen $\mathrm{i}$ juni havde få et uskadt hertil, og som stod på en mølle tæt ved, ville efter al sandsynlighed være bleven ødelagt eller gået op i luer. Vi sparedes for denne ødelæggelses vederstyggelighed. Mod slutningen, da general Wilster ${ }^{31}$ havde fået overkommandoen 
over de her omkring liggende tropper, kom der mere fasthed $\mathrm{i}$ ledelsen - de tidligere hyppige forandringer af indkvartering hørte op, og stemningen bedredes $i$ det hele, dog ikke anderledes end at, da budskabet kom om fredens slutning, der her i prastegården var idel sang og klang og lystighed trods de gyselige betingelser, at der hørtes udtalelser af de herværende officerer "at nu skulle de ind til København og børste de forbandede avisredaktører." Jeg følte mig som en spurv i tranedans, var fuld af sorg over den grusomme, ulykkebringende fred og skammede mig i mit inderste over officerernes udtalelser; de var $3 \mathrm{i}$ tallet; men jeg vil ikke sætte deres navne på papiret; de 2 er iøvrigt døde, flere år tilbage, den 3die lever; det volder mig bedrøvelige minder, hver gang jeg hører eller ser hans navn.

Hvor heldigt min tidlige ansættelse i Føns i mange måder var, havde den sine skyggesider; først ved min samtale med provsten fik jeg at vide, at nådensåret for enken var forlænget fra mandens dødsdag i februar til min udnævnelsesdag d. 6. maj. Følgen deraf blev, at nådensåret blev for mig så uheldigt som muligt. Hovedindtægten var avlingen; som kaldet efter 1. maj tilkom der mig ikke en smule af årets høst, men jeg skulle desuden betale hende det halve af værdien af vintersædens høst 1865; det beløb sig til mellem 4 og 500 rdl., og hele min netto indtægt af nådensåret var knap så meget, så at jeg bogstaveligt kan sige, at et helt års indtægt for mig gik aldeles tabt. Enken hang ved præstegården til den yderste termin 1. maj 1865, så jeg måtte underholde min familie hele den lange tid på fremmed sted, og havde jeg ikke velvilligt fundet en gård i Føns sogn, hvor der var lejlighed til, at de kunne bo, var jeg kommen i en endnu større gald, end jeg kom. Gården lå på Rud, en god $1 / 4$ mil fra præstegården og beboedes af sjældent rare mennesker, navnlig var konen en ren perle - velsignet være hendes minde - hun modtog min hustru, lærerinde og 6 børn med den største gæstfrihed og hjalp dem, så godt hun på enhver måde kunne og blev en trofast veninde og elsket til sin død af os alle.

Desuden viste sognenes beboere sig fra den bedste side; der bragtes min kone en stor mængde fødevarer, så at det kød, der købtes, indskrænkedes til et minimum, desuden smør og æg, brændsel; der var en møller, som sendte hende halvdelen af en stor gris foruden andet, og der var næppe noget større gilde $\mathrm{i}$ sognene, uden at de sendte hende store kurve fulde af deres herligheder. Der boede så familien fra september 1864 til 1. maj 1865, da den kunne holde sit indtog i præstegården - og levede vi der så gode og lykkelige år til 1875, da jeg kom til Vissenbjerg. Dog det er ikke årene i Føns og Vissenbjerg, som skal beskrives, dem kender både I børn og børnebørn af egen erfaring; så jeg vender tilbage til årene i Slesvig.

Også de var at kalde gode, de havde deres strid, bryderier og bekymringer, 
og tilsidst var tiderne i Husby strænge, men meget var dog også det gode, som Gud der havde gemt til os, også der har jeg ofte måttet bekende med tak til Gud: "Jeg er ringere end al den miskundhed og trofasthed, som Du har bevist din tjener."

Jeg har omtalt, hvorledes forholdene i Hyrup var bedre og lysere end $i$ de fleste sogne i Angeln, der kan jeg sige, levede jeg 7 år som ven blandt venner men også i Husby havde jeg om end færre dog ikke så ganske få trofaste venner, hvorom jeg i flere år fik vidnesbyrd ved de breve, de sendte mig, både gamle og unge, og hvoraf en del er bevaret indtil denne dag.

I de uafladelige angreb på sprogreskriptet og voldsomme agitationer mod samme, var der jo idelig opfordring for os, som var medvirkende til dets prøvelse og til selvprøvelse og hvor tit og ofte, det har været genstand for min overvejelse, er resultatet for mit vedkommende bleven fuld anerkendelse af dets grundsætning: Dansk i de rent danske dele - tysk i de tyske - og blandet i de blandede distrikter, og det med så billig og hensynsfuld udførelse som menneskeligt muligt, og at sprogreskriptet for Husby og Hyrup sogne var fuldt berettiget og retfærdigt, fremgår jo af de omtalte virkelige sprogforhold. Jeg kunne derfor Gud ske lov, forlade Husby med den bevidsthed, at jeg der havde haft en god og retfærdig sag at arbejde for og har aldrig haft nogen besværet samvittighed eller følelse af skam over, at de der tilbragte 12 år, der trods alle bitre erfaringer og de endelige skuffelser, dog af mig bestandig regnes som gode. Dertil bidrog blandt andet også det venlige og hjertelige samliv og sammenhold mellem os præster, der alle var omtrent af samme alder, havde samme interesser og opgaver og som så tit erkendte og udtalte for hinanden, at et sådant samliv ville vi intetsteds genfinde, hvor vi kom hen, og ikke mere falde i vor lod. Men fremfor alt takker jeg Gud for de mange erfaringer, jeg i de år gjorde af, hvor godt og velsignet det er at leve sit liv i "Guds søns tro, som elskede os og gav sig selv hen for os", for al den trøst og opmuntring i fred og glæde den giver, for den vidunderlige kraft, mod og håb, der i trange tider dog kan løfte hjertet op over deres pinagtigheder, så at vi "bedrøvede dog kunne være glade“; "om vi trænges dog ikke forsage, tvivle dog ikke fortvivle, forfølges dog ikke er forladte «. - og disse erfaringer har kun stadfæstet sig $\mathrm{i}$ de følgende år og dog i nogen måde ladet mig sande $\mathrm{Chr}$. Richardts ord ps. 788: "Vel dig, som gik med ham i livets trængsler - for dig går dødens port på lette hængsler; vel mig en stav jeg kan af korset skære, da går jeg let, hvor vejene er svære." -

Gud hjalp mig og os alle dertil, at vi må erfare tilsidst, at i denne tro er det saligt at dø. -

Pastor Simonsen blev, som man kunne vente og var forudsagt, min 
eftermand; nogle dage før min afrejse kom han til Flensborg, men ikke til præstegården. Allerede medens han boede i Holsten og stundom fik besøg af Husby'ere, sagdes han at have svaret dem, der klagede over kirkesproget: "I kan jo nok forstå det, gå I bare i kirke. «Så vidt var han bleven sandheden tro! Men hvilken mislyd i klagernes øren. Men der kom flere og vel værre. Han tiltrådte embedet 1. påskedag - med hvilke følelser vel, og allerede 2. påskedag vakte han vennernes forargelse; han begyndte, tilskrev man mig, sin prædiken med en beklagelse af, at deres salmebog var så fattig på gode salmer - og det var den tilvisse - særlig på festsalmer; da var den danske salmebog (vor convents salmebog, som var indført i skolerne, men ikke i kirken, hvor den tyske endnu brugtes, også når tjenesten var på dansk) ganske anderledes rig på gode salmer, navnlig festsalmer; der går en påskeklang igennem dem, og det er jo vigtigt, thi påsken er moder til alle søndage og festdage; når I kommer hjem, kan I jo tage den danske salmebog og gøre en sammenligning." Han boede de første uger ikke i præstegården - konen var sindssyg - men hos den ved anløbet på mig d. 9' febr. omtalte Peder Jensen; en pige fra samme by, som af mig var forberedt til konfirmation skrev til mig, at hun et par gange var fulgtes med præsten, når han fra P. Jensen gik til præstegården, hvor han fortsatte deres undervisning - dog kun 3 gange. En anden skrev til mig, at præsten havde udtalt sig rosende over den forberedelse, de havde fået, og en tredie, at præsten havde holdt overhøringen af konfirmationen på dansk, hvad der havde foranlediget en af de forargede at beklage sig over - men ikke fået andet svar af præsten end: Ja, Lorenz Simonsen bleibt Lorenz Simonsen und Pflicht bleibt Pflicht.« Hans gerning i Husby var dog kun kort, 4. eller 5. søndag efter påske havde han en lang tjeneste - først 2 børn at begrave - kirkegangskone at indlede - prædiken stor altergang og endeligen brudevielse - men som han lige var færdig med den - blev han ramt af et apoplektisk slag, og han gik - stum fra kirken og kom der aldrig mere! Seer man ikke her Guds finger! Det er tydeligt for mig. Han levede så nogle måneder i præstegården, kom så vidt, at han nok til nød kunne sige enkelte ord, men hjernen var angreben; havde nogen tid hjælpepræst, fik så sin afsked eller tog den, levede sine sidste dage i Flensborg. De huslige forhold vedbleve at være sørgelige; konen var nok kun få dage $\mathrm{i}$ præstegården og måtte som sindssyg føres til Slesvig, hvor hun siges at være død nogle år efter på anstalten. Så vidt jeg ved, havde de kun 1 søn, hvis skæbne jeg aldrig har hørt omtale. $-^{32}$

\section{Appendix}

Audiens hos Frederik d. 7de på Lyksborg.

$\mathrm{Da}$ jeg en dag var tagen til Lyksborg for at forhandle om en sag med 
minister Wolfhagen, ${ }^{33}$ opfordrede han mig til at søge audiens hos kongen. Jeg undskyldte mig med, at jeg ikke vidste, hvad jeg skulle bringe på bane for kongen.

Han, ministeren vedblev at opfordre mig dertil; der var netop så let adgang til kongen, da der den dag var så få, der ønskede audiens. - Jeg måtte give efter og blev meldt. Kongen var underrettet om, hvem jeg var, og hvor jeg var. Da jeg står for ham, siger han: "Nå, De er jo en af de præster, som arbejder derude i de blandede distrikter, hvordan går det?" Jeg svarede: "Ret godt, Deres Majestæt! jeg er så heldig at bo i et dansktalende sogn, hvor majoriteten er dansksindede og har været kongen tro.. "Nå! det glæder mig; jeg ved, at præsternes stilling er vanskelig derude, der er jo så mange, som er imod sprogreskriptet, $i$ den sag må der arbejdes med lempe; vi må ligesom sømanden i stormvejr snart fire og snart hale. Nu skal De høre, hvordan det gik mig forleden dag, jeg kørte en tur her i omegnen, var selv kusk og Røde sad bagpå; jeg var kommen ind på en vej, jeg ikke kendte, ser en mand stå inde på marken og råber ham an og spørger på tysk, hvor vejen førte hen, så svarer han til min overraskelse på dansk. Nå, kan du tale dansk, det kan jeg også og så talte vi videre på dansk. « Da jeg dertil bemærkede, at det måtte have været en ærlig dansksindet mand, da det ellers var almindeligt, at de tysksindede over for andre, der ikke kendte dem, så længe som muligt søgte at skjule, at de talte dansk - fortsatte han: "Jeg var nylig ovre ved Tønder, der [kom] så en deputation og beder mig, om at sprogreskriptet måtte blive ophævet. Nej, svarer jeg kort, deri sker ingen forandring, det er min vilje og derved bliver det! Da jeg så spørger dem, hvad har I forresten at klage over, så svares Gud hjælpe mig, på dansk: Ingen ting!! Deres Majestæt, “ og så lo han højt og jeg med, og jeg gik fornøjet og med lettet sind fra den uventede audiens. Et år holdt kongen fødselsdag på Lyksborg, vi præster blev underrettet om, at da strømmen af gratulanter var så stærk den dag og pladsen på slottet så indskrænket, ønskede Hans Majestæt at se os præster i Flensborg provsti til taffels dagen efter fødselsdagen. Vi mødte selvfølgeligt. Da vi var komne til bords mønstrer kongen med sit blik forsamlingen og udbryder da: »Biskop Boesen! der mangler jo 1 i din sorte bataillon! « Den talte 25 og der var 24 . Ved taflet var der en livlig stemning, og efter det måtte vi blive en stund, og kongen gik omkring mellem os og samtalede i al gemytlighed med os, med al sin nedladenhed dog bestandig så værdig, at vi følte, vi var gæster hos kongen! Jeg ved heller ikke af, at der fra vor side blev vist nogensomhelst taktløshed.

Af taflets gode retter erindrer jeg kun, at vi fik - vildsvinesteg, som jeg dog ikke tror satte nogen af os i henrykkelse. Det var både første og sidste gang, jeg var til taffels $\mathrm{i}$ kongesale, og har heller ikke beklaget det, ej heller næret noget ønske om at komme der. 
Men det har ofte været og er endnu den dag i dag min begæring og bøn, at jeg må komme en gang til at sidde tilbords i Guds rige hos vor himmelske Konge og der samles med mine hensovede kære og de endnu levende børn og børnebørn, således at mor og jeg på den sidste store Herrens dag må kunne sige, når vi skal åbenbares for Hans domstol: See, her er vi og de børn, Du har givet os, vi har ingen mistet af dem, som Du har givet os!

At det håb må opfyldes, så arbejde enhver af os på sin saliggørelse, at dog ingen af os ved sin vantro, ubodfærdighed, verdsligt og kødeligt væsen skal forspilde sin børne- og arveret til Guds rige. Du, o Gud! ophold os i vor dåbs nåde og velsigne og bevare os i vor dåbspagt indtil enden. Så ere vi - hvordan vor lod og lykke ellers skal falde i verden - vel farne!

27. april 1899.

\section{J. H. Nissens breve til A. Regenburg}

I et brev til Regenburg dateret Odense d. 27. august 1851 henviser Nissen til bekendtskab fra falles skolegang i Sorg' og sporger, om der kan vare udsigt til en "ikke fjern befordring" til et gejstligt embede $i$ "den landsdel, på hvis forholds ordning De udøver en så heldbringende indflydelse“. Efter at have givet nogle selvbiografiske oplysninger fortsatter Nissen. "Hvis jeg nu personlig havde lejlighed til at forebringe min sag for Dem, ville De måske spørge mig, hvorfor jeg ej før har søgt ansættelse, da der var større trang på og vanskelighed ved at få brugbare kandidater til præsteembederne i Slesvig, og mit svar måtte da blive, at en af hovedgrundene er, at jeg har næret tvivl om at opnå ansættelse, da jeg kun ønsker den i dansktalende menigheder, og ikke hvor menigheden er så blandet, at der udkrævedes oftere eller sjældnere prædiken og præstelige forretninger udførte på tysk og dette ikke så meget af hensyn til personlig behagelighed og bekvemmelighed som af ulyst til at udtale det højeste og bedste man har på et sprog, som for mig aldrig kan blive hjertets, om jeg end tør antage, at jeg snart kunne tilegne mig den nødvendige mundtlige færdighed. En anden grund er den tilfredsstillelse, jeg føler med min nærværende virksomhed; men da jeg dog ønsker at ombytte denne med den præstelige, har jeg $\mathrm{i}$ den senere tid oftere følt mig tilskyndet til at henvende mig til Dem med en sådan forespørgsel. At den kommer nu, er foranlediget ved, at jeg i disse dage har set Halk præstekald i Haderslev provsti averteret vakant, og efter den betydelige afkortning indtægterne lider, synes det mig ikke ubeskedent at ansøge herom. Om jeg imidlertid gør dette, vil bero på, om De synes, det er tilrådeligt, og de nærmere oplysninger, jeg måske $\mathrm{i}$ så tilfælde tør imødese om ovennæunte kalds og menigheds 
beskaffenhed, navnlig den ikke ringe pension til den afgåede præst.... Nissen slutter brevet med at tilbyde at fremsende manuskriptet til en af ham $i$ Odense holdt pradiken og en kvalificeret bedommelse af den mundtlige udforelse.

Odense, d. 12te okt. 1851. Først min tak til Dem, kære hr. Regenburg, for den velvilje, hvormed De imødekom mig under mit ophold i Flensborg... Herefter folger en udtalelse om unavngiven person, som Regenburg har onsket oplysninger om. "... Om forholdene i Hyrup læste jeg $\mathrm{i}$ »Fyens Avis« igår aftes et stykke taget af Kolding Avis, hvor præst, skolelærer, sandemand og "Rechensmand" bliver hårdt medtagne og navnlig svigersønnen betegnet som en foragtelig person $\mathrm{i}$ "religiøs, moralsk og politisk henseende«; derfor ønsket udtalt om en kristelig og dansksindet mands ansættelse. Ved nærmere undersøgelse af kaldets beskaffenhed har jeg fundet, at Heidscheffel i dansk mål kun indeholder $42 / 5$ skæpper land, hvorved arealet synker ned til ca 60 tønder land. Dette i forbindelse med det prekære i de uvisse indtægters størrelse opfordrer mig til at forespørge, om det er uundgåeligt, at der skal af kaldet udredes den hele pension til den entledigede. Kan ikke en del af de $500 \mathrm{mk}$. overføres på den slesvigske kasse? Jeg får, efter hvad der er blevet mig fortalt, nok forresten en konkurrent $i$ en kateket Steenbuch ${ }^{2}$ her af byen, for hvem jeg, hvis ancienniteten tillægges vægt - han er 3 a 4 år ældre kandidat end jeg med laud - må befrygte at komme til at vige pladsen. Som barn af byen er han formodentlig minister Bardenfleth ${ }^{3}$ personlig bekendt. Det, hvorpå jeg da skulle kunne bygge mit håb, er næst Deres velvilje måske nogle karakterens egenskaber, som jeg uden at ville insinuere noget mod ham, tør tro mig i besiddelse af forud for ham. Når det nu - formodentlig snart - bliver opslået vakant, og tiden til ansøgningernes indlevering er forløbet, og det da viser sig, hvilke konkurrenter jeg har, tør jeg måske vente - muligt igennem Monrad ${ }^{4}$ nogle vink om min status. Jeg er, kan jeg ikke nægte, efter hvad der er passeret, meget opsat netop på dette kald, men lægger forresten min skæbne i Deres hånd...."

Deres med sand højagtelse forbundne J. H. Nissen.

I et brev af 8. dec. 1851 skinner N.s utålmodighed m. h.t., om han får embedet $i$ Hyrup, igennem. Han sparger om Kvarn, som også skal besattes.

Den 7. januar 1852 kan han imidlertid takke Regenburg for hans medvirken til, at han har fäet embedet i Hyrup. "... Gud give nu, at den [kaldelsen] måtte 
blive til fælles tilfredshed og glæde og menighedens gavn! Jeg har allerede $d$. 3'die januar skrevet til superintendenten, om han ville behage at bestemme dagen for min ordination, hvorpå jeg hver dag venter svar, og derefter skal jeg da følge Deres anmodning - som jeg på denne måde antager sker fyldest - at skrive til amtmanden om min introduktion. Reimuth ${ }^{6}$ var vist rejst fra byen han er huslærer på en gård ved Assens - da jeg modtog Deres brev, men jeg skrev straks til ham. Han er vistnok i flere henseender vel kvalificeret til ansættelse, thi blandt andet har han gode talegaver og taler flydende tysk og er et meget gemytligt menneske. Kühnel ${ }^{7}$ har jeg naturligvis bragt Deres concilium abeundi. ${ }^{8} \mathrm{~J}$ eg tror, at han vil være særdeles velskikket til sin post og hans valg således meget heldigt..." $N$. fortsatter med at skrive om egne økonomiske forhold. Han har sendt en ansøgning til ministeriet om et lån på 600 rdlr. fra den slesvigske kasse, efter at han har fäet afslag på et andragende om et privat län. De 600 rdlr. er det dobbelte af, hvad han har talt med Regenburg om, og som var det normale. Han har imidlertid en gald på 300 rdlr. og hertil kommer flytteomkostninger, anskaffelse af prastekjole, et par heste, vogne, koer etc., som han beregner til 6-700 rdlr. I alt har han altsả behov for ca 1.000 rdlr., og han beder nu om Regenburgs hjalp til at opnå lånet.

Hyrup, d. 14'de marts 1852.

Højstærede hr. Regenburg.

Efter løfte meddeler jeg Dem herved lidt om tilstanden i og uden for skolen, således som jeg efter disse få ugers ophold har opfattet den. Såvidt jeg erindrer, meddelte jeg Dem mundtligt, at jeg ved mit første besøg $\mathrm{i}$ underklassen fandt denne, hvad færdighed $\mathrm{i}$ dansk læsning angår, meget tarvelig. Da jeg senere udtalte mig derom til hjælpelæreren, ${ }^{10}$ undskyldte han sig med, at han aldeles ingen instruks havde erholdt, hverken fra den ene eller anden, kun i almindelighed vidste, at dansk skulle indføres, og så efter bedste skøn havde så meget han turde (det vil sige læse 1 time daglig med unger af meget forskellig alder; alt andet gik på tysk). Jeg gjorde ham da bekendt med reskriptet; " dets indhold var ham fremmed, forsikrede han. Jeg pålagde ham da naturligvis nu straks at tage ganske anderledes fat, således at vi efter skoleeksamen - $\mathrm{i}$ ugen før påske - kunne begynde på at gennemføre det $\mathrm{i}$ hele sin udstrækning. Børnene kommer jo $i$ skolen uden at kunne tale et ord dansk; der må altså i førstningen skrides lidt forsigtigt om end fast fremad. Ved mit sidste besøg i skolen, omtrent 14 dage efter det første, sporede jeg en ikke så ganske ringe fremgang og en ikke ringe lyst hos børnene. Det er uheldigt, at han ikke vil blive her længere end omtrent til september, da jeg anser ham for brugbar til at bringe sagen i gang. - I overklassen ${ }^{12}$ er naturligvis så godt som intet gjort; på tabellen figurerer 2 timer ugentlig til 
dansk læsning, men efter sigende er dette ikke engang udført. Da jeg spurgte ham, om det var al den tid, der var anvendt til dansk, bejaede han det og føjede til, at han forgæves hos provsten ${ }^{13}$ havde udbedt sig nærmere ordre. Provstens besked havde været, at det måtte han gøre efter bedste skøn, fire og klemme på efter forholdene! De læser derfor i det hele utilfredsstillende enkelte naturligvis undtagne, som har særdeles lyst. Jeg havde ham for $i$ onsdags efter mit sidste besøg og pålagde ham nu at benytte tiden og hjælpelærerens vejledning til sin egen forberedelse for efter eksamen at kunne begynde så lempelig undervisningen også i denne klasse på dansk. Dertil svarede han: "Ja, skal der gås synderligt videre end nu, så må jeg søge min afsked." "Det bliver naturligvis Deres sag, jeg har kun villet minde Dem om, at således, som det er, kan det ej blive og har for Deres egen skyld rådet Dem til at benytte tiden og lejligheden til egen uddannelse." - "Ja, jeg er nu for gammel til at lære dansk, vil kun prostituere mig, og desuden står i min bestalling, at jeg er blevet ansat ved en skole, hvor undervisningssproget er udelukkende tysk." - "Ja, når De hverken kan eller vil etc. - må De naturligvis søge Deres afsked.“ - Dagen efter var jeg hos amtmanden, ${ }^{14}$ fortalte ham dette, og han anmodede mig da om at sige til ham, at han skulle gøre det jo før jo heller. Dette har jeg naturligvis sagt ham, og han svarede da kort, "at det måtte vel være ham tilladt at gå til amtmanden og tale med ham, da han mulig kunne ønske dette, inden han bestemte sig til at indgive sin ansøgning." At forbyde ham at gøre dette står jo ej i min magt, så lidt som at befale ham straks at indgive sin ansøgning om afsked. - Men i morges fik jeg et lille vink om, hvor han vil hen. Der blev mig nemlig fortalt, at der igår aftes skal have været et møde, som der formentes $i$ anledning af at samle underskrifter til en begæring om at fritages for dansk skolelærer (måske også i kirken!) og formodentlig også om at beholde ham, de har. Hvorvidt sagen er fremmet, ved jeg ikke, men det er ej usandsynligt og står rimeligvis i forbindelse med, hvad der påtænkes andetsteds. Jeg har nemlig hørt, at "die Achtmänner und Kirchenjuraten ${ }^{15}$ i deres sidste møde - jeg tror i søndags hos pastor Lassen ${ }^{16}$ i Adelby skulle have haft den frækhed at forelæse et stykke af Scheels fragmenter ${ }^{17}$ om hr. Regenburgs fortjenester i Angeln, spurgt præsten, om han ville underskrive en påtænkt petition om at få dansk ud af kirke og skole, og når han ej ville det, erklæret, at så stillede han sig $\mathrm{i}$ fjendtligt forhold til dem og sognet!! Martin Monrad ${ }^{18}$ er hjemmelsmand. Måske hr. Jessen har i sinde at gøre amtmanden bekendt med, at hele sognet nærede ønsker om at beholde ham! Jeg vil håbe, at amtmanden vil feje ham ordentlig; han kender dog hans færd. Klagen over hans Wühleri ${ }^{19}$ efter proklamationen af 28. $\mathrm{j} .{ }^{20}$ fra kommandanten i Angeln har naturligvis ej ført til noget. Ergerligt er det, at de virkeligt dansksindede, hvoraf her i Angel 
dog er nogle, ikke vil ud med sproget. Alle, hvem jeg har spurgt derom, siger, de ved intet om dette og er i det hele så forbeholdne og frygtsomme i deres udeladelser. - Iøvrigt går her alt vel, tilsyneladende i det mindste. Der er færre i kirke til dansk prædiken end til tysk, men dog en meget anstændig forsamling. Kirkegangen er her god; nogle er der hver eneste gang, deriblandt Gregers Gregersen, Gregers Nissen; også den ærede Rechensmann ${ }^{21}$ såvelsom Peter Sager møder stadig også til dansk tjeneste. Rechensmannen taler fortræffeligt dansk. Jeg har i den sidste uge haft for meget at bestille til, at jeg har kunnet komme omkring hos de tyske beboere, og i denne uge sker det ej heller, da jeg har tillyst, at jeg næste søndag ønsker mit manteloffer, ${ }^{22}$ og jeg ej vil, det skal se ud, som om jeg kom for at bejle til deres penge - som sådant blev det naturligvis udlagt! - Jeg er nu temmelig længselsfuld efter at få en bekræftende meddelelse om min ansøgnings udfald om lån. Bach ${ }^{23}$ vil veje mig til det yderste; vor Auseinandersetzung ${ }^{24}$ kommer upåtvivleligt til visitatoriets erklæring og måske videre; vær mig da nådig! Hansen ${ }^{25}$ i Husby mener, at de der i den sidste tid er tammere; at der er slyngler i hans sogn, har jeg i det små erfaret med en, jeg købte brænde af, som hører dertil, og som har snydt mig. Jeg troede det bæst for godt og blev da taget lidt ved næsen, som han tidligere har gjort med Hansen, og efter hvad jeg hører, er det hans daglige forretning. Med ønske om, at hr. Jessen snarest muligt må få sin afsked, når begæringen indkommer, og at der må findes en dygtig efterfølger - dygtig er han! - forbliver jeg

Deres meget forbundne J. H. Nissen.

Hyrup, d. 13'de april 1852.

Højstærede hr. justitsråd.

Nu påskens travlhed er forbi, iler jeg med at give Dem nogle meddelelser om sagernes stilling her. Såvidt jeg erindrer, skrev jeg sidst, at jeg havde haft først skoleforstanderne og næste dag dem med ottemændene for $i$ anledning af petitionssagen. ${ }^{26} \mathrm{Da}$ der efter denne konference hengik omtrent 14 dage, uden at der kom noget til min kundskab om sagens genoptagelse her i sognet, troede jeg den her stillet $\mathrm{i}$ bero. Det var imidlertid en sangvinsk forhåbning, som er blevet til intet. Presset formodentlig af adelbyerne og husbyerne og Wühlerne her, har ottemændene med den unge Marquard Gregersen i Veseby, søn af Rechensmann M. G., i spidsen fået en sådan i gang og med de sædvanlige midler fået så godt som alle til at underskrive, så at selv - mænd som Gregers Nissen -, der udtrykkeligt tidligere havde sagt mig, han ej underskrev; han sagde mig igår, jeg bebrejdede ham det: "det var for konens skyld, der ikke kunne finde sig i, at de bestandig skulle kaldes oprorere; han 
havde ikke sovet natten derefter! - Jürgen Petersen, Andreas Hansen (ligl. "for konens skyld“), Peter Wuhnsen, Gregers Gregersen i Weseby etc. har gjort det. Kun en af ottemændene, Johan Marxen har ej og bliver nu forbigået med foragt af de arrigste af hans kollegaer. Jens Matthiesen - der præsenterede ham den til underskrift og erklærede ham, at han handlede meget slet med ej at gøre det - Marq. Greg. etc.; foruden ham høkeren Jørgen Fries, som de gør alt for at ruinere, et par i Nielsgårde og en 5 a 6 andre i Hyrup; i Weseby kender jeg ej dens skæbne, men der har de formodentlig alle underskrevet. De kender den imidlertid måske alt bedre end jeg, da den enten er afgået eller $\mathrm{i}$ disse dage afgår til ministeriet. En deputation har været påtænkt som overbringer; den skulle efter en tidligere bestemmelse (have) været mig vist, men efter hin aftens samtale er det formodentligt opgivet. Hvad der styrker dem deri er de "gode efterretninger, som Adelbydeputationen har hjembragt; ministeren ${ }^{27}$ havde ingen anelse om, at sagen stod således i sognet; han troede, det var beboernes ønske, dansk underv(isning), d(ansk) prædiken! men nu havde han lært sagernes rette sammenhæng at kende etc « - således fortælles der! At husbyerne er mulkterede, er, fordi de har skrevet på ustemplet papir. - Jeg troede dette logn som det andet, men hørte rigtignok igår af amtmanden, som var hos mig, at det virkelig er af den grund. Det har hyrupperne sikret sig imod ved brugen af stempelpapir. Såre ønskeligt var det rigtignok, at de, som står i spidsen herfor - det er her den unge Marquard Gregersen i Weseby - og de, som have gået omkring med den og terroriseret til at underskrive, bliver alvorligt straffet og det ej med en blot pengebøde - det måtte $\mathrm{i}$ al fald være noget følelig - med vand og brød; afsattelse fra deres bestilling (dette hed var sket i Adelby, men med dem alle, og derfor satte de en ære deri). Der er igennem oberstløjtnant Wilster, ${ }^{28}$ der $\mathrm{i}$ disse dage ligger i Husby, sket indberetning til amtmanden om, hvad her er sket. Han har haft begge Marquard'erne for sig, men med hvad frugt! Jeg må se det først! Igennem oberstl. Wilster er atter andraget på Marq. Greg.s afskedigelse som Rechensmann, og derover tror jeg, det nærmest var, amtmanden ville tale med mig; han bør afsted; men vil amtmanden ikke udtrykkelig befale en anden til at vare det, fåes ingen i stedet, da ingen godvillig overtager det, navnlig ikke den som her. Såvidt jeg har kunnet erfare det, er mest skikket dertil Jürgen Petersen; han undskylder sig med, han bor på hospitalets grund. Jeg har nu talt med et par om, hvem der kan bruges og skal endnu i dag ind til amtmanden og meddele resultatet. Af alt dette uvæsen, som nu er i fuld gang, og som i de magre (?) sogne upåtvivlelig vil føre til ekscesser. - Sørupper har her i kroen erklæret: Lad soldaterne først komme vel bort, så skal vore danske embedsmænd og dansksindede bønder nok få ben at gå på - vil De noksom erkende det ønskelige og nødvendige i, at 
vi snarest muligt får vor skolemester afskediget - flere dansksindede har i den seneste tid nærmet sig ham, fordi de ej kunne udholde, som de siger, at skulle høre, at de er skyld $i$ hans afskedigelse. Amtmanden syntes mig ej at være fuldkommen overbevist om, at hans fjernelse iværksættes. Derom kan jeg dog ikke nære tvivl. De kender jo af tidligere meddelelser hans færd meget bedre end jeg. Nu er han vel tilsyneladende villig til at gøre, hvad han kan, men så længe han bliver, vil sagen her kun få ringe fremgang. Med hans fjernelse, Rechensmannens afskedigelse, alvorlig afstraffelse af lederne og en dansk, dygtig skolelærers ansættelse vil her, det håber jeg, snart blive orden. Så snart befolkningen ser det skal være, troer jeg næppe her skal møde nogen modstand af betydning. Der har allerede meldt sig hos mig et par aspiranter til skolelærerembedet, som efter anbefalingerne at dømme vil være vel skikkede dertil. En sådan ansættelse vil også virke gavnlig på underlæreren, hvis bortgang til efteråret, jeg efter lidt nøjere kendskab til der næppe bliver grund til at beklage. Får Jessen sin afsked, da bliver til grund for hans pension dog vel lagt hans opgivelse af embedet til krigsskat, jeg tror den var 746 rbdlr. c., medens han i ansøgningen opgiver det til 1100 rbdlr. c.; men derpå har visitatoriet $^{29}$ nok alt gjort opmærksom; jeg ved dette $i$ al fald kun af amtmanden. - Da jeg endnu intet svar har fået på min ansøgning om lån-der var skrevet på ustemplet papir - begynder jeg at tvivle på opnåelsen heraf. Hvis det er Dem muligt, ville en meddelelse herom være mig såre kærkommen, da jeg i den nærmeste tid, skal bruge mange penge til indkøb af køer, som er betydelig dyre. - Hansen i Husby har jeg på grund af denne tids travlhed ej set længe. Nu efter påskens 5 prædikener - l'ste påskedag prædikes 2 gange - ånder jeg i så henseende friere. Min familie fik jeg hertil kort før påskeugen. Hansen $\mathrm{i}$ Grundtoft ${ }^{30}$ har jeg ej heller set i 3 uger; de var begge sidste gang samlede hos mig. I Grundtoft er det gode, at der er nogle determinerede danske; det er der ikke her; dertil har de her ej lidt nok, hvis dette forresten havde bevaret dem for den gode sag. Deres ord om, at de givne bestemmelser skal overholdes, var mig beroligende; uden det sker, er det også åbenbart, at så godt som alt er tabt. Jessen har ytret her, han hørte ikke gøgen i Hyrup! Stadfæstelsen heraf håber jeg på hver dag.

Med sand højagtelse Deres forbundne J. H. Nissen

Højvelbårne hr. justitsråd, departementschef

Regenburg, R. af Dbg.

Højstærede hr. justitsråd.

Hyrup, d. 5. juni 1852.

Det var naturligvis med særdeles tilfredsstillelse, at jeg modtog det høje 
ministeriums gode besked til petitionærerne, og at vi alle fik bekræftelse herpå ved den nye bekendtgørelse, der 2'den pinsedag ${ }^{31}$ blev oplæst. - Her var den dag tysk prædiken og adskillige af nærmeste vedkommende i kirke. Denne gang løb ingen sin vej, og de nøjedes med på hjemvejen at give ondt af dem. - Peter Sager »fandt det afskyeligt, at provsten, der ikke selv kan dansk, kan sætte sit navn under en dansk bekendtgørelse af sådant indhold «, som de forresten kun "ad anelsens og formodningens vej begreb “ - naturligvis! Men jo bestemtere disse ministeriets svar har været, desto ønskeligere, at min degn med hans ligesindede fjernes, og det er navnlig af en lidt utålmodig længsel derefter, at jeg i dag skriver. Jeg har, indtil vi fik ministeriets svar, ej været uden frygt for, at jeg kom til at beholde ham, men i dette læste jeg også hans entledigelse, og den indædte harme, som han havde ondt ved at skjule og hvormed han oplaste det - naturligvis slet - vidnede om det samme hos ham. Men idet afgørelsen opsættes, oplives hans og hans velynderes håb. Man har sagt mig, at han endnu i de sidste dage har ytret, at han agtede at skrive igen til ministeriet for at få besked (han må ingen ynder af svævende tilstande være), og at han med sin bestalling i hånden, hvori der står, han er ansat ved en tysk skole, nok skulle lære dem at give ham $900 \mathrm{mk}$. i pension. Man har ligeledes fortalt mig, at han for Thomas Knudsen på Harresby, ${ }^{31}$ hvor mine breve indlægges, har bebrejdet sognefogden fra Adelby, da denne omtalte, at han havde fået den sidste bekendtgørelse til udbredelse, at han ville befatte sig med noget sådant: "Nej, da havde vi en anderledes Rechensmann, han skulle nok vogte sig for det“ (desværre sandt) og ved synet af visitatoriets brev til mig, der lå på bordet, udbrød han: "Det er vel sagtens det samme kram, vi skal have. Det skal nok få lov at ligge for mig « - dermed et stød med tilhørende talende gestus til brevet! Han er naturligvis komplet øjentjener mod mig, har navnlig efter store bededag, som jeg benyttede til at sige adskillige sandheder, (Fischer ønskede Marquard Gregersen med et håndtryk ved udgangen af kirken "Velbekomme«; "de var gået hjem med alle fikker ${ }^{32}$ fulde“ etc.) øjensynlig anstrengt sig for at behage mig - men i hvad ånd han arbejder fremdeles, viser ovennæunte ytringer til overflødighed. Det er derfor beklageligt, at der ved hans henholden i embedet gives skin af, at regeringen, som han siger "er $i$ forlegenhed med ham", "den kan ikke undvære ham «! (Underlæreren, som De måske ved, er urtekræmmersvend, vil gå af $\mathrm{i}$ begyndelsen af septbr.) Jeg er ikke uden frygt, det tilstår jeg, for at nogen skyld kan hvile på mig, idet måske en mere indtrængende erklæring om det ønskelige $i$ hans afgang, end den jeg med mit davarende korte bekendtskab til ham afgav, kunne have fremskyndet den. - Kirkebesøget er fremdeles godt; det ringeste antal jeg har haft ved en dansk tjeneste var l'ste søndag efter påske - slet vejr, de mange forudgående helligdage bidrager vel 
Provst Aleth Sophus Hansen. (Dansk Centralbibliotek for Sydslesvig).

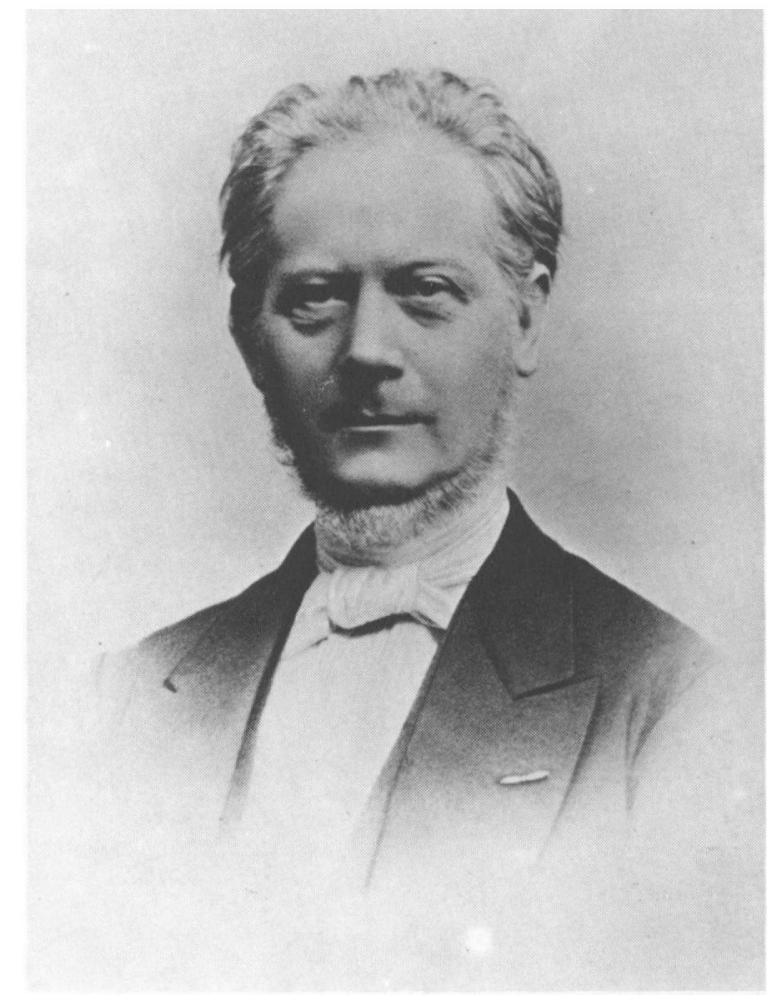

noget dertil - hvor der var c. 30 (menigheden er 700); men den tyske bliver endnu stadig besøgt ikke lidet talrigere (det ganske Weseby kommer med en enkelt undtagelse ej til dansk tjeneste) - også herpå influerer sikkert degnen; det er vel imidlertid utvivlsomt, at disse sidste bekendtgørelser (når han kommer bort) vil ophjælpe den, skønt de endnu sætter deres håb til fremtiden: "Mit der Zeit wird es wohl anders werden" er nu deres omkvæd. Flere af mine petitionærer ærgrer sig nu over, at de har underskrevet den. Det andragende, hvormed vi danske præster på sidste konvents møde, er indgangne til ministeriet om ophævelse af fællesskab med Galster $i$ "Landesbibelges(elschaft) “ ${ }^{33}$ behøver næppe anbefaling til justitsrådens særdeles opmærksomhed. De få tyske præster, der vare tilstede, Aschenfeldt, Peters, Christensen $^{34}$ fra Medelby, Simonsen ${ }^{35}$ og Andresen ${ }^{36}$ stemte for fællesskabets vedbliven. - De 2 førstnævnte kæmpede tappert nok - væsentlig af frygt for, at vort skulle blive et filialselskab af det k(øben)havnske, hvorpå ingen forresten af os holdt. Er det uundgåeligt, at Boesens psalmebog ${ }^{37}$ skal 


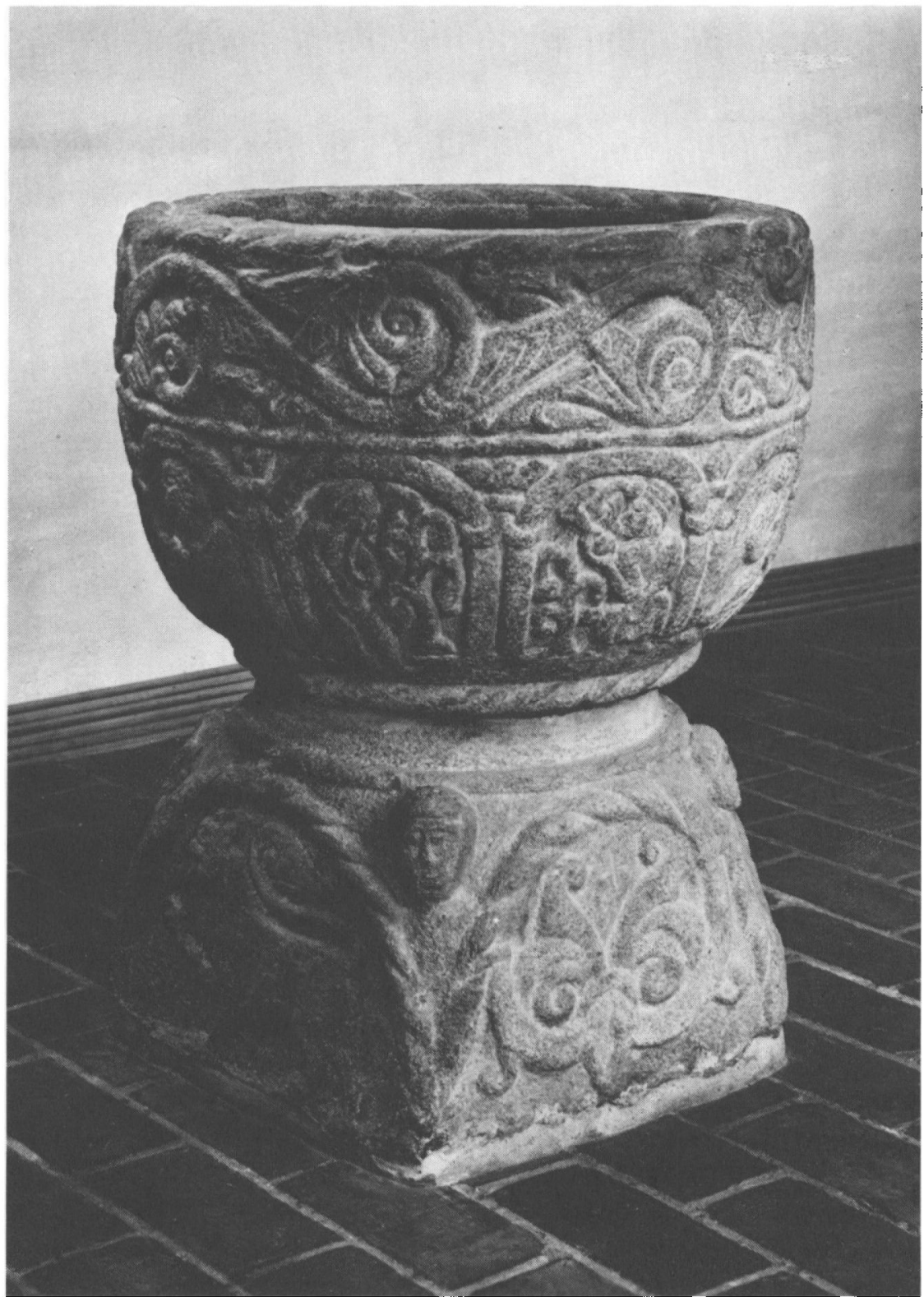

Romansk dobefont i Husby kirke. (Postkort: Gerd Remmer, Flensborg).

indføres i skolerne? Det vil i flere henseender have sine ulemper, selv om det tillades, at den roskildske bruges ved siden af. Jeg tror da, at det var heldigere 
at blive udelukkende ved Boesen af narliggende grunde. - Caterim censeo, Thomas Jessen esse delendum. ${ }^{38}$ Hansen $^{39}$ i Husby venter hver dag en arving, han var ej ved konventet derfor, Hagerup ${ }^{40}$ ej heller af mig ubekendte grunde.

Med særdeles højagtelse Deres forbundne $J$. H. Nissen

\section{S. T.}

Hr. justitsråd Regenburg R. af Dbg.

Hyrup pstgd (præstegård), d. 25'de okt. 1852. Når jeg ikke tidligere har bragt hr. departementschefen min lykønskning til etatsrådstitlen - den forfremmelse der af alle vakte mest glæde hos mig - har dette fornemmelig sin grund $i$, at jeg gerne med det samme ville meddele Dem lidt nærmere underretning om sagernes stilling her og derfor har måttet se min nye skolelærers virksomhed lidt an. Thi dette er hovedbegivenheden her $\mathrm{i}$ sognet, at den gamle Wühler endte sin virksomhed - i det mindste i skolen Mikkelsdag, og at jeg havde den fornøjelse at indsætte Ebbesen ${ }^{41}$ fra Dollerupskov i embedet d. 4. oktober. Han kommer vel anbefalet for sin dygtighed og nidkærhed for sagen derfra, og hans troskab har jo stået sin prøve i hans tidligere stilling i Løjt. Den gamle gik herfra "entrüstet" med løfte om ej at ville sætte sine ben her ( 0 : formodentlig hos præst og degn, der visselig ej sørger derover), og efter at have moret sig med at fortælle, at præsten ville smide ham ud (o: at jeg havde sagt til Ebbesen, at hans indtægter og ret til at flytte ind $\mathrm{i}$ boligen var fra Mikkelsdag af at regne -). Om Ebbesen ytrede han, at man straks kunne se på ham, at han var »befangen «. ${ }^{42}$ Hansen $\mathrm{i}$ Husby har fået ham med, han bor i Ousager ${ }^{43}$ og driver kvæghandlen på kraft, som han alt her var slået ind på. Ebbesen vil nok bringe sagen $i$ god gang i skolen. Fra l'ste septbr. har jeg også haft en dygtig underlærer, ${ }^{44}$ en seminarist fra Skårup. En virkning sporede jeg straks; børnene i overklassen havde hidtil, takket være Jessen, slet ikke benyttet de danske bøger, der i juni måned blev skænket til et bibliotek her, de i underklassen derimod ganske ordentligt. Så snart jeg nu havde anmodet Ebbesen om atter at minde børnene derom, at danske bøger var til stede til udlån, kom straks den første dag, han gjorde det, på en gang 10 drenge og senere stadig adskillige til, som ville have dansk læsning, så at der i dette øjeblik i dette lille sogn er 34 - hvoraf de fleste er skolebørn, i skolen er ialt ca. 90 -som får danske bøger tillåns. Om end en del vistnok for syns skyld er dragen med, er det dog en god begyndelse. Oppositionen fra tysk side - en del mødte ved indsættelsen, som jeg holdt på dansk - er nu naturligvis også vakt, og navnlig er der en skummel karl i Weseby, om hvem det $i$ torsdags blev mig meldt, at han havde ladet sine børn tage deres bøger, tavler etc. hjem med fra skolen, som de ikke mere agtede at 
besøge, da de skulle have en huslærer. Jeg havde da straks personen for og blev lidt overrasket ved øjeblikkelig at se ham så myg. Den eneste grund til hans beslutning var »den lange skolegang«. Han havde rigtignok tænkt på at holde en huslærer, men det var en mangeårig tanke og havde dertil udset en fra Adelby sogn afskediget lærer Philipsen, ${ }^{45}$ der som drukkenbolt nu var $\mathrm{i}$ Munkbrarup fattighus; men jeg måtte for alting ikke "anbinde « ham, at han havde villet gøre dette uden først at have fået mit samtykke etc. etc. - Efter at jeg havde sagt ham besked, endtes sagen med, at børnene skulle komme i skole igen i dag, hvad jeg endnu i dag naturligvis skal have undersøgt. På et besøg i Sundeved blev jeg bekendt med en ministeriel skrivelse til Åbenrå visitatorium, hvorved det ganske lægges $\mathrm{i}$ dets hånd at afgøre, hvem en mand må have til huslærer. Kunne denne bestemmelse ikke blive udstrakt her til provstiet? Nogen gavn for sagen og glæde for adskillige præster ville det dog sikkert have. Med kirkegangen er det her som hidtil upåklageligt - dog bestandig en hel del færre til dansk, men dog dertil mellem 30-60-70. Jeg tillyste igår 8 dage, hvad jo måtte ske, at altergangen igår, der var dansk tj(eneste), ville blive på dansk; men der "var“ denne gang endnu ingen, som havde mod, omend enkelte måske lyst til at melde sig, hvad der iøvrigt ej overraskede mig. En del trosindede har endnu ondt ved at forsone sig ret med sprogreskriptet, men den bedre erkendelse vil sikkert her snart gøre sig gældende. Jeg har dog con amore afgivet en af herredsfogden afæsket erklæring om vor regningsmand Marq. Gregersen og herredsfuldmagtig ${ }^{46}$ Peter Sager og håber, at denne ofte omtalte og hidtil strandede sag nu endelig må blive afgjort på ønskelig måde. De danske har her været en del alarmerede ved Peter Sagers påtænkte rejse til dyrskuet i København. Han kom selv imidlertid ej længer end til Kiel, fik buksefeber og vendte hjem. Sagen har vakt en del opmærksomhed og er jo ej heller gået ubemærket hen $i$ København. De har måske også hørt om den, og jeg vil da for mit vedkommende ligefrem fortælle sammenhængen, som jeg overhovedet slet ikke har lagt eller lægger skjul på, hvad jeg i denne sag kan have forsømt. Jeg fik $\mathrm{i}$ august måned gennem amtmanden med påtegning fra ham om at interessere mig derfor, et trykt brev fra komiteen, hvor der tales vidt og bredt om en udstilling af landøkonomiske produkter etc, og det er alt, hvad der er kommet til mig. Min individuelle mening var straks, at det ville være frugtesløst at forsøge at vække interesse derfor hos beboerne, da deres agerdyrkning, havesager etc. ej er af den beskaffenhed, at det kunne ventes nogen lyst hos dem til at indsende prøver deraf. Jeg talte med nabopræster derom, og de var af samme mening og - jeg gjorde intet ved sagen, der var af ren privat natur. Jeg havde imidlertid ingen anelse om, at det kunne være en hemmelighed for nogen, hvad alle aviser, og nogle holder dog Flensb(burger) 
Zeit(ung), omtalte, indtil omtrent 8 dage for dyrskuet en mand kom til mig og spurgte, om jeg ej kunne give ham nogen oplysning om dyrskuet. Jeg viste ham da straks, hvad der til nogen oplysning om sagen o: dyrskuet var kommet til mig og meddelte ham forresten, hvad jeg af avisen vidste derom. Da var nemlig rygtet kommet hertil ved en mand fra $\mathrm{Bau}$, som amtmanden havde henvist til at lade sine kreaturer følge med Peter Sagers til Kiel og derfra med dampskib, at denne længe havde vidst det, man listigt nok holdt det hemmeligt, selv for sin nærmeste slægt. I deres mistænksomhed faldt de straks på, at amtmanden havde villet holde det hemmeligt for dem og indladt sig med Peter Sager derom. Denne tro er formodentlig blevet bestyrket hos dem ved, at amtmanden, en dag i begyndelsen af oktober besøgte mig, også var hos P. S. og dette - amtmandens besøg hos en erketysker! - vakte naturligvis stor opmærksomhed og sattes i forbindelse med hin sag. Ligeledes vrøvlede de om, at da de havde fået et par kvier, som de ville sende med Vesper (?), var der fra amtshuset lagt dem hindringer i vejen o: amtssekretæren kendte ikke den dyrlæge, som havde udstedt attest for deres sundhed og forlangte derfor en sådan fra en ham bekendt. Og nu endelig Peter Sager præmie, de ingen! Nok til at vække mistanke og tro på forurettelse. Jeg beklager naturligvis, at den skrivelse, jeg i sin tid fik, ej blev bekendtgjort; men åbenbart er det, og det vedgår de selv, først ved kundskaben om Peter Sagers hemmelighedsfulde rejse, at iveren derfor blev vakt; uden det havde sikkert ikke en eneste rørt sig her. Om samme P. S. fortælles der iøvrigt i anledning af Københavnerrejsen følgende lille bidrag: En navngiven mand opfordrede ham hos en købmand i Flensborg til, når han kom til København at virke til befrielsen fra "den tortur med det danske ", "men det kan ej nytte, du går til ministeren, men til kongen og læg ham det rigtig for, hvor meget det er os imod." "Ja" skal han have svaret "jeg skal nok gøre, hvad jeg kan navnlig hos professor Schmidt ${ }^{47}$ (De ved han er husejer og har 2 brødre boende i Weseby), til ham har jeg breve og hos ham venter jeg at komme til at bo." Dette foranlediger mig til at omtale, at samme ærede professor, der i sommer lå med familie her hos brødrene i 3 måneder, ej havde sine ben $\mathrm{i}$ præstegården og så vidt jeg ved ej heller i kirken - naturligvis vand på de tyske wesebyers mølle - men af hvad grund? Mon fordi jeg ej har besøgt hans slesvigholstensksindede broder, der formodentlig har anbefalet mig på det varmeste? Eller af hvilken anden? Det ville ikke være uden interesse for mig at vide lidt derom. Er professorens tanker om sagen og dens stilling her i sognet ej Dem bekendt? Hvis så er, ville et par ord derom lejlighedsvis være mig kærkomne. Han er jo nu atter i Flensborg og har også været i Weseby. Naboerne har det vel; Lassen, ${ }^{48}$ Ehrenreich, ${ }^{49}$ Hansen i Husby har jeg talt med i den forløbne uge; med den med Levinsens ${ }^{50}$ søster i Quern forlovede 
Hansen i Grundtoft er det lidt længere siden. For valgene synes her i sognet endnu ingen interesse, og der ventes intet godt deraf, - Kongens Geburtsdag ${ }^{51}$ blev af en del hyrup'er fejret med sang og klang på kroen, og de har lovet hinanden hvert år at samles $\mathrm{i}$ den anledning (hele byen, de fleste tyske og danske var først samlede $i$ anledning af et byregnskabs fremlæggelse - og tyskerne måtte drikke den første bolle med, men tøflede så af, og 11 a 12 danske festede da til ud på natten).

Deres med sand højagtelse ærb. forb.

J. H. Nissen

Hyrup, d. 7. febr. 1853.

At hr. etatsråden i det nye år ikke før nu har set noget fra mig, har væsentlig sin grund $\mathrm{i}$, at sagerne her går deres jævne gang, og jeg tør sige efter omstændighederne ret godt. Man synes nu at finde sig i min nye degn, omend ikke med behag - det var jo heller ikke godt. Siden de 3 Weseby piger blev taget ud af skolen og sat i Petersens Institut ${ }^{52}$ i Flensborg, er en datter af vel meriteret Peter Sager vandret samme vej - hans plan er ikke ringere end af bondepigen med træsko etc. at få dannet en gouvernante, hvortil hun særlig skal føle sig kaldet; begavet er hun; tiden vil vise, om der virkelig er ånd og vilje til at gennemføre det; hun siges på egen hånd at have lært sig noget engelsk. Nu er, som De formodentlig fra anden side er gjort opmærksom på, hr. Petersen blidelig henslumret. Om latinskolen i Flensborg i den anledning har fejret hans gravøl, ved jeg ikke; men glæden over hans forventede død var så stor hos i det mindste en af lærerne, at han vistnok gerne havde tømt mindets bæger. Deres principale håb er naturligvis, at instituttet for drenge dermed også er dødt, deres subsidiære, at hvis det skal leve, det da må komme til at virke i ren modsat ånd. Idet jeg kun kan dele deres ønsker, er det tillige med en smule håb om, at få Weseby pigerne tilbage her til skolen. En dreng fra Weseby er ligeledes taget ud af skolen og nyder nu godt af en seminarists ${ }^{53}$ undervisning, der er huslærer i Grimmerup i Husby sogn. Jeg havde naturligvis papa for mig; han gør det jo af den ømmeste omsorg for sin søns størst mulige uddannelse og har af denne grund jo ikke kunnet modstå svogerens tilbud at tage hans søn i huset hos sig, naturligvis uden betaling! Således kan man jo ej forhindre det. Hansen arbejder og, efter hvad jeg har hørt, med held på seminaristen, har forestillet ham det tåbelige $\mathrm{i}$ at lade sig engagere som huslærer og dermed forspilde sin fremtid og rådet ham til snarest muligt at søge hjælpelærerpost. Han er en skårup'er, er villig gået ind herpå, og der skal alt være udsigt til, at han bliver ansat i Sørup. Med udlånet af bøger går det godt; en ikke ringe del børn læser flittigt; i reglen er mellem 50 og 60 bøger i den senere tid ude på gangen; enkelte ældre kommer også med; 
navnlig er der rift om nogle skildringer af krigen, jeg efter anmodning var så heldig at få fra komiteen $\mathrm{i}$ København ${ }^{54}$ ved nyårstid, og de er formelig abonnerede ud. - Med kirkebesøget må jeg også være tilfreds. Valget af stænderdeputeret fik jo ej det ønskelige udfald; det var skade, at Krüger ${ }^{55}$ ikke havde haft en sammenkomst med dem i forvejen - det var regningsmanden, der frarådede det. - Han var dem, jeg kan vist sige 99 af 100 aldeles ubekendt, endog af navn. Det var den ene grund, man hørte, hvorfor de havde betænkeligheder ved hans valg, den anden: Frygt for at whan var for dansk“. Det forkla redes så derhen, at de var bange for, han skulle trænge på, at "de gar inte tysk sku'e ha'e». Upåtvivleligt var der fra tyskerne i den tid udspredt det rygte, at nu skulle der snart kun prædikes tysk hver 3 'die søndag, så hver 4'de etc. Dette hørte man stadig, når man talte med de dansksindede om valget; her stemte 6 for Krüger, 8 for Henrichsen. ${ }^{56}$ I grunden ønskede de fleste af dem, der gav Krüger deres stemme, at den anden måtte blive valgt, i det mindste var det her let at mærke, at de ville have en, om hvem de kunne sige, han har varet tro under krigen, men - som så er mod sprogreskriptet. Derfor erklærede de også efter valget, at de var fornøjede med Henrichsens valg, for "de havde dog gjort, hvad de skulle“ (stemt på Krüger) (og fået den de egentlig ville have). Han havde også efter valget "gjort en fe'it net tale«! Naturligvis kommer der rigeligt forsynede petitioner ind; om de danske her også denne gang for en del skulle underskreven, får vi nu at se. De gør det da ikke, fordi de tror på nogen forandring, men af svaghed og jammerlighed, og fordi indstillingen om det tyskes uundværlighed også har smittet dem. Det, man også ofte hører, er dem til anstød, er, at de i Flensborg har så lidt dansk i skolerne, og hvorfor skal det ikke være ens, føjer de så til, og man har ondt med de grunde, man kan anføre, at bringe dem til anden erkendelse. En sagde således til mig, at han også havde spurgt "gelehrte» i Flensborg om grunden, og han havde svaret, det var »städtische Freiheit« for at lette "Verkehr ${ }^{57}$ men den grund, sagde han så, dur ikke, for vi behøver også tysk for vor Verkehr! ja vist, derfor er det også, at jer børn skal have 4 timer undervisning om ugen etc. etc. - men at 4 timer skal kunne udrette, hvad hele deres skolegang kun så dårligt har udrettet, er dem gåden! Til sidst indrømmer de så dog, at de godt kan sælge deres heste og køer på dansk - men vanen er angelboens ikke anden, men hele natur. Fortræffeligt er det, at der i den senere tid kommer danske herned og køber deres køer. Her var nylig på en gang 4, 2 fra Fyn og 2 jyder, og dem har de făet respekt for, det var "gesche'ite ${ }^{58}$ Folk ", som nok kendte, hvordan "Keufferiet " ${ }^{59}$ skal være - og dertil betalte de enorme priser og var dog godt tilfredse. Vist er det, at danskheden har gjort ikke ringe fremskridt og vil under en rolig udvikling $i$ decennier have vundet mere terræn end tyskeriet $\mathrm{i}$ århundreder. Man har alt 
den tilfredshed at høre småbørnene i underklassen, når de går hjem fra skole, at tale dansk, og dog er der i foræld renes hus til dem ej talt og tales der endnu i det hele taget ej dansk. De er i almindelighed kommet såvidt, at de siger: „Ja, nu skal vi til at tale dansk med dem, men det falder os så løjerligt! « Det vakte derfor $\mathrm{i}$ begyndelsen almindelig forbavselse, at jeg talte dansk med min 2 års pige, og at hun kunne forstå det! - En anden sag, for hvilken der synes vakt en del interesse, og som de har sagt at ville petitionere om, er ophævelsen af fællesskabet med Holsten. - Forordningen om erstatning for krigsskade har vakt stor glæde: "Der kan man dog se er gjort forskel på en tysker og en dansker." Her er, mig bekendt, 3, som vil nyde godt deraf. Uheldigvis mangler kontrasten, jeg tror ikke, der er nogen tysker, der har lidt nogen skade. Det er nemlig danske tropper, som har kunnet lugte, at kartoflerne var lagt af danske hænder og derfor ladet dem smage sig. - Jeg ser dog af et extranummer af Dannevirke, at Fædrelandet er forbudt i Slesvig. ${ }^{60} \mathrm{Jeg}$ har ondt ved at tro det, men det er ikke det eneste i den senere tid, der er kommet ikke med overraskelsens glæde. At skille Fædrelandet fra den sag, hvori vi nu her i stilhed virkede, er umuligt. Fastelavnsmandag har mindet stedet om livets alvor. Endnu har jeg ikke et øjeblik fortrudt, at jeg sidder her. Det er mit håb, at Deres ord "for de trufne foranstaltninger $i$ kirken og skolen har jeg ingen frygt« vil blive bekræftet af udfaldet, og så vil jeg forhåbentlig med samme fortrøstning som hidtil arbejde $\mathrm{i}$ kirkens og den sags tjeneste, som også er hellig, fordi den er retfærdig.

Deres med sand højagtelse forbundne

J. H. Nissen

\section{S. T.}

hr. etatsråd, departementsdirektør

Regenburg

Højstærede hr. etatsråd!

Hyrup præstegård, d. 4'de april 1853.

Årets travleste tid er forbi og giver ikke længere noget påskud til at lade de stille fattede forsætter vente på udførelse. Blandt de første af disse hører nogle meddelelser til hr. etatsråden om sagernes gang etc. Som det omtrentlig vigtigste punkt vil jeg nævne det meget tilfredsstillende udfald, som den nylig afholdte skoleprøve havde - mandagen før Palmesøndag. For at få selv og give beboerne, der ville benytte lejligheden, et ordentligt begreb om skolens tilstand, lod jeg skoleprøven være således, at den kan siges at svare til sit navn; lod derfor overklassen udelukkende examinere om formiddagen $\left(8 \frac{1}{2}-12 \frac{1}{2}\right)$, 
underklassen om eftermiddagen. Som sædvanlig åbnede den med sang, derefter katekiserede degnen over et ham opgivet tema af troslæren på dansk, bibelhistorien på tysk, læsning i tysk testamente, læsning i Hjorts læsebog, oversættelse af et stykke fra dansk på tysk af samme, geografi og historie på dansk, og det hele gik overmåde godt; en 15 a 16 gamle - kun få tyskere - var tilstede, og en af dem i det mindste (Gregers Nissen, i hvis gård De introd(duktions)dagen kørte ind) har erklæret mig, at han aldrig havde hørt prøven gå bedre, og alle må erkende, hvorledes de er tilfredse, at det gik godt. Det ønskede jeg så meget mere, som degnen hidtil har været dårlig anskrevet hos næsten alle. Han er noget hidsig og opfarende og ragede uklar så med en, så med en anden af de danske, også noget mundkåd og næppe fri for i skoletiden at lade ytringer falde til børnene, som ikke der hører hjemme, hvorved han har pådraget sig ord for at vare "tumpet", "ikke rigtig ved Sinnen« etc. - meget af hvad der er sagt, har jeg ligefrem beviser på er usande. Således fortalte en af skoleforstanderne, som jeg havde for, at jeg en dag havde været i skolen og taget tampen fra degnen - ikke et ord sandt! Ingen har klaget til mig over, at han bankede børnene og altså slet intet derom. Han er ganske vist en meget dygtig lærer og har vistnok også mere end almindelige skolemesterkundskaber, så det fejler næppe, at en bedre erkendelse om hans værd efterhånden må gøre sig gældende, og begyndelsen antager jeg er gjort med denne prøve. Var han kommet omtrent samtidig med mig, ville jeg med rolig samvittighed kunne have konfirmeret i år på dansk. Han kom nu først en måned, før jeg begyndte at læse med konfirmanderne, og selvfølgelig gik undervisningen på tysk, kun har jeg en enkelt gang taget den holdte danske prædiken på dansk med dem og katekiserede i kirken de danske onsdage $\mathrm{i}$ fasten på dansk, første gang uden at børnene vidste det mindste derom, og det gik fortræffeligt. Et par af konfirmanderne, som jeg har villet spørge derom, erklærede også, at de konfirmationsdagen kunne have svaret lige så godt (og måske bedre) på dansk. Efter påske ": i dag har vi begyndt undervisningen aldeles efter reskriptet. Hvorledes tyskerne iøvrigt udlægger det gode udfald af prøven, fik jeg at vide for et par dage siden i løbet af en 3 timers samtale med Peter Sager: Det var altsammen indexerceret med børnene i forvejen! atter usandt!, da jeg dagen (søndag) i forvejen opgav degnen, hvad han skulle katekisere over. - Jo! jeg har nylig haft en sådan samtale med Peter Sager; han kom nemlig en dag $\mathrm{i}$ forrige uge til mig, trykkede mig varmt $\mathrm{i}$ hånden $\mathrm{og}$ med rystende stemme bekendte sig som en synder!, smuk indledning til den derefter følgende erklæring, at han ved konfirmationshandlingen, prædiken langfredag og 2'den påskedag "hatte mich lieb genommen “ ${ }^{61}$ etc, hvortil jeg naturligvis kun kunne svare, at det fornøjede mig, hvis han havde følt sig tiltalt derved, men formente dog, at når han ikke tidligere havde det, lå det 
vistnok $i$, at han havde modtaget mig med fordom etc; det vedgik han straks, og som jeg ventede kom det da også frem, at mine prædikener på St. Bededag og min "Eidespredigt “ ${ }^{62}$ havde været ham så "anstössig “ ${ }^{63}$ - det er nemlig som dagen og teksten opfordrer til de 2 gange, hvor jeg har måttet berøre det ømme sted og rigtignok mere end berøre, men er dog rolig for ej at have overskredet den rette grænse. I samtalens løb fik jeg jo god lejlighed til at sige ham adskillige sandheder. Han vedgik, at her og i nabosognene taler flertallet dansk, men han har naturligvis alt for ondt ved at forsone sig med sprogreskriptet af de sædvanlig fortærskede grunde. Så aldeles lette er mine ytringer ej gået hen over ham; næste dag fik jeg et iøvrigt meget velskrevet brev, vor samtale havde besværet og beklemt hans hjerte, så at han kun kunne fange liden søvn! og den smule han fik, drømte han stadig om samtalens genstande og beklager, at han havde gjort mig den tilståelse, da han nu frygtede, at han ville have mere skade end nytte af samtalen; dernæst en del veklager over de tomme kirkestole på danske søndage etc. etc. med bøn om min forbøn for hans bedre belæring, om ny samtale etc. Den skal han få, når han har summet sig lidt; han er mig velbekendt en meget hul broder, dertil meget skinhellig, men på den anden side tror jeg dog, han er bragt så vidt, at han i øjeblikket vakler og har svære indre kampe. Denne historie med ham har interesseret mig en del, og jeg ser nu, at der måske er skrevet meget mere derom, end De har interesse af at læse. Datteren, som De måske erindrer (jeg tror at have skrevet det), han sendte til Flensborg for at dannes til gouvernante, sendte han næste dag til mig, for at jeg skulle læse min påskeprædiken, således som den var gået igennem hendes hoved og pen, og af en 13-årig pige, der indtil for kort tid siden kun har besøgt en landsbyskole, var præstationen unægtelig særdeles god. - De ved formodentlig andetsteds fra, at Kühnel ${ }^{64}$ prædikede 2'den påskedag i Marie kirke, hovedsagelig for at sondere stemningen med hensyn til hans præsentation til diakonatet. Jeg har af Monrad, der besøgte mig forleden, med megen glæde hørt, at han har vundet almindeligt bifald. Hans valg ved siden af Peters ville $i$ mange henseender være en stor vinding. - Men hvad skal det blive til med den bebudede visitats? Der er kun eet ønske om, at den må være veloverstået, men også een almindelig frygt - De ved nok hvorfor. Skal spørgsmålet om en generalsuperintendent - det er vel nærmest det? - være afgjort, inden man tør håbe at have en provst, som kan visitere i reskriptets ånd? Gid de da begge var vel løste! - Jeg hører i dag, at Høcker i Sørup ${ }^{65}$ er død i nat. Det er Dem vel næppe nogen nyhed, når De modtager disse linier, der mulig ikke her øjeblikkelig se lejlighed til at komme til Flensborg. Hagerups ${ }^{66}$ forlovelse med Barfods ${ }^{67}$ svigerinde er Dem naturligvis en gammel nyhed. Kollega Hansen i Grumtoft er siden sin forlovelse blevet aldeles usynlig for gamle 
bekendte - skønt hun er i Ålborg -, næsten hele vinteren har hverken Hansen i H. eller jeg set ham. Hans tanker og sind går nok uafladeligt mellem Ålborg - Grumtoft - Quern. Ehrenreich lever i idyllisk ro, der kun forstyrres ved hans datters syngeøvelser, der dog endnu ikke røber, at hun har nogen sands derfor. Rygtet fortæller, at Thomsen ${ }^{68}$ søger 3 kald i Holsten - og hvad jeg dog vil håbe er rent usandt eller en forfærdelig overdrivelse, at 21 børn af Stenbjerg s. skulle være druknede på én gang på Langballig å; omendskønt han, der fortalte det her i dag, sagde, at han igår havde hørt det fra mange sider, trænger det til betydelig stadfæstelse og er derfor kun bestemt til Deres udelukkende kundskab. En mand siges at have mistet 4 børn. Det er dog forhåbentlig vel kun det bekendte lyvetalent, der nu forsøger sig i en ny retning! $!^{69}$ - I de sidste dage, navnlig igå $r$ har vi haft en svag fornemmelse af, at vintermånederne skulle være forbi. På landet er længselen efter foråret vel større end $\mathrm{i}$ byerne, i det mindste har vi flere daglige glæder dermed. For at ende, hvor jeg begyndte: Underlæreren, ${ }^{70}$ som har været her siden 1'ste septbr., dimitteret i sommer fra Skårup, er desværre af visitatoriet i Tønder fra påske af kaldet til skolelærer i hans fødeegn. Han var meget brugbar som underlærer, om han har kraft til at bestride en skole på ca. 100 børn må tiden vise. Er forholdene ikke vanskelige der, frygter jeg ej, da han har godt greb om tingen.

(Hyrup, udateret, 1854)

\section{Højvelbåme}

hr. etatsråd, departementschef Regenburg. R. af Dbg.

Da jeg efter en samtale, jeg nylig har haft med hs. højvelbårenhed biskoppen, må antage, at salmebogssagen ${ }^{71}$ fra hans hånd er indledt eller vil påny blive ført frem for ministeriet, vil jeg, da mit navn muligt i den anledning kan komme herr etatsråden for øje, skønt jeg vel tror, at den part jeg muligt kan have fået $i$ dens fremskynden fra biskoppen er af liden betydning, da den sikkert også uden den samtale snart ville blive indledt, dog ikke undlade at meddele hr. etatsråden, hvad der af mig i den sag blev forebragt. - Efter at have talt med $\mathrm{Mohr}^{71 \mathrm{a}}$ og mig, som samtidig var hos biskoppen, om forskellige det liturgiske vedkommende ting, ytrede biskoppen: "Nu må vi også snart have dansk salmesang til den iøvrigt danske gudstjeneste, da det er unaturligt at synge tyske salmer til danske gudstjenester « etc. - Ja vistnok, Deres Højærværdighed, tillod jeg mig at svare, når man betragter sagen abstrakt, men med forholdene for øje i de sogne, jeg er kendt, turde det måske være tilrådeligt at udsætte den sag, da det muligt kan have til følge, at man dermed kan tabe kirkegængere, da adskillige af disse er gamle folk, som har 
ondt ved uden foregående nærmere kendskab straks at læse den danske salme, synge med etc. - Biskoppen indlod sig ej derpå, men gentog omtrent de samme ord og føjede til »og så er det en selvfølge, at den salmebog, som de alt har i skolen, og der er autoriseret, også skal bruges $\mathrm{i}$ kirken, noget jeg allerede har talt med ministeren om. Enhed må der være - og det er jo i provstiets skoler min - Ja! Deres Højærværdighed, men den er kun tilstede i skolerne i et $\mathbf{i}$ forhold til børnene ringe antal, kan kun medgives en del af dem til hjemmebrug, og man har, såvidt jeg ved, ikke nogetsteds forlangt, at noget barn eller konfirmand skulle anskaffe den (jeg ved ikke rettere end at alle mine kollegaer har ladet sidste års konfirmander ved forberedelse bruge skolens eksemplarer) - Og hvorfor ikke? - fordi Deres Højærværdighed! den sag hidtil har stået noget in suspenso. ${ }^{72}$ - Da er det jo en selvfølge, at den salmebog, som bruges i skolen, og som der er autoriseret, også skal bruges i kirken; det har jeg også ministerens ord for, der må være enhed etc. - Det har dog været dem tilladt, som måtte ønske det, at anskaffe Roskilde Convents. Tilladt! har kirkevisitatoriet? - Ja! Deres Højærværdighed. Herredets præster har et cirkulære derom? et cirkulære fra hvornår? må jeg bede Dem om en afskrift deraf; det er en sag, som skal bringes i orden, jeg har ministerens udtrykkelige ord for, at den, der bruges i skolen« etc -

Således var $\mathrm{i}$ alt væsentligt samtalens gang, som jeg efter den vending, den fik, vel må ønske ej var ført, men bragt på bane af biskoppen, synes mig, at jeg ikke vel har kunnet tage den anderledes, end jeg tog den. - Da jeg ikke ville, at vor ærede amtmand skulle være uvidende derom, indtil han fra højere steder bragte i erfaring, at sagen var optagen, gik jeg samme dag til ham og fortalte, hvad der var passeret.

Iøvrigt går sagerne deres jævne gang; i skolen kunne det gå fortræffeligt, hvis degnens personlighed var heldigere; han er desværre lidet agtværdig fra karakterens side; hans huslige forhold, i hvilke det er en yderst vanskelig sag at indblande sig og at kunne påvirke, er af den natur, at de er til almindelig forargelse, uden at de dog har det offentlighedens præg, som de, hvis han ikke agter de givne vink, næppe tidligere eller sildigere vil undlade at få. Så meget mere at beklage, som han er en meget dygtig vel begavet lærer! Der er i dette lille sogn anbragt 14 børn andetsteds. Kirkebesøget til dansk tjeneste er her i reglen 30 a 40 , stundom nogle få derunder og en del derover.

Jeg ser, at pastor Siemsen nu er entlediget. Trykket af den efter mit embedes beskaffenhed betydelige pension til min formand og af det første års ringe indtægter og dermed større gald, end anskaffelse af de nødvendige landbrugs rekvisiter gjorde uundgåelig og familiens stadige tilvækst etc. etc. vil Etatsråden blandt ansøgerne vistnok også finde mit navn; deres tal bliver måske ikke ringe, og jeg kommer muligt kun til at veje lidt. Dog benytter jeg 
lejligheden til at anbefale mig til fremtidig befordring og til, at Hr. Etatsråden vil have mig i velvillig erindring. ${ }^{73}$

Med sand højagtelse

ærbødigst

J. H. Nissen.

Hr. etatsråd, departementsdirektør Regenburg.

Hyrup præstegård, d. 22'de jan. 1856.

Skønt rygtet siger, at den kur, som i den senere tid i de højere regioner har været påtænkt at skulle anvendes på den "syge mand» herovre, igen er opgivet til glæde for dem, der mener, at den anvendte behandling netop er probat, og forandring i samme, hvor ubetydelig den kunne synes, højst farlig og betænkelig, vil jeg dog ikke undlade på ny at gøre Dem bekendt med hans befindende her i sognet. I en henseende er der med det nye år foregået en meget glædelig og længe ønsket forandring til det bedre. Siden oktober ${ }^{74}$ har vi her ingen underlærer, som var brugbar, kunnet få, og som følge heraf har degnen selv måttet overtage undervisningen $\mathrm{i}$ begge klasser, hvis børnetal tilsammen kun er ca 70 . Ved årets slutning har imidlertid skoleforstanderne ikke desmindre udbetalt degnen både præparandlønnen(her 48 rdlr. årlig) og godtgørelsen for hans kost etc. ( 5 tdr. rug og 16 rdlr. årlig) også for de 3 måneder, hvor der ingen præparand har været. Jeg troede først, at det var en tankeløshed af den noget enfoldige skoleforstander, som er regnskabsfører; kaldte dem derfor til mig, den afgående med den ny tiltrådte og til min behagelige overraskelse erklærede de alle 3 enstemmig, at det var vel betænkt; dels havde de rigtignok giort det, fordi der i tidligere lignende tilfælde ikke var sket noget afdrag, men navnlig fordi de mente, at degnen havde fortjent det, at han, siden han overtog begge klasser, havde gjort sin gerning til almindelig tilfredshed, havde afholdt sig fra hans tidligere taktløst og upassende snak til børnene og i det hele med flid og iver taget sig både af store og små, så at de gik med større lyst til skole end de havde gjort i den tid, hvor den sidste rigtignok mindre heldige underlærer var her. Fremdeles erklærede de, at hvis han blev ved, som det nu var, ville de også for fremtiden ikke have noget imod, at han beholdt i det mindste en betydelig del og måske det hele, der af kommunen ellers udredes til underlæreren. Det er en overraskende spendabilitet; al billighed taler vel for, at han fik præparandens løn, men at de også vil lade ham beholde kostpengene i det mindste tildels, overgår min dristigste forventning. Alle 3 skoleforstandere (jeg tager den afgående med) er rigtignok danske; den ene er Gregers Nissen, bulderbassen ved kirken, som De måske har $\mathrm{i}$ behagelig erindring fra min introduktionsdag, men han har 
sålidt som overhovedet nogen af de danske tidligere været velvillig sindet mod degnen. Det er således mit glade håb, at den uvilje mod sagen, som hans personlighed har vakt, for fremtiden vil være fjernet og dermed er meget vundet. Min virksomhed ville have været betydelig lettere og behageligere, dersom det havde været så fra begyndelsen. - Der er kun ringe udsigt til, således som han er udskreget, at vi får nogen underlærer $\mathrm{i}$ den herskende mangel på brugbare subjekter; men jeg er nær ved at tro, at det har været målet for hans stræben, væsentlig vel på grund af hans huslige forhold. Han har nu vist, at når han vil, kan en sådan her undværes. Peter Sager, som i sin sidste petition til stænderne skrev "von religiösen Standpunkte betrachtet sind die Früchte (!) der Verkündigung des Evangel(iums) in einer uns unverständlicher Sprache betrübend, ja himmelschreiend ${ }^{75}$ Det skriver han, som 1845 eller 46 var den ene af dem, som oversatte et stykke af evangeliet på dansk, og som forstår det bedre end de fleste, og som sikkert godt kan bruge det, når han på kvæghandelens vegne gør rejser til Jylland og Fyn. Han har dog efter den tid ladet de to børn, han endnu har i skolen ( 2 har han i Hedeby) anskaffe hvert et dansk testamente til hjemmebrug; i skolen er vi vel forsynede dermed. ${ }^{76}$ Kirkebesøget er, hvad den danske tjeneste angår, efter forhold og omstændigheder ganske ordentligt: 2'den juledag og nyårsdag, hvor vi havde dansk, var der over 60 mennesker til kirke og i reglen mellem 30 og 50 (hele folketallet er 600). De fleste af dem, som er konfirmerede på dansk, besøger dog her stadig den danske prædiken. Kommunikanternes antal har i det sidst forløbne år beløbet sig til 556 og har dermed på det nærmeste nået, hvad det var, før min ansættelse; 1851 var det nemlig 568. Nytårsdag lod en født holstener, som har været her et par år, og som nu er bleven kirkeværge, sig uden allermindste anmodning om at blive indsat på tysk sig tage i pligt i kirken på dansk, formodentlig til ikke ringe anstød for hjemmetyskerne. Uagtet hans nærværelse i fattigkollegiets møder vistnok havde vakt håb for tyskerne om, at forhandlingerne nu skulle blive ført på tysk og $i$ det små forsøg fra deres side var anstillet, går det som sædvanligt på dansk. Når vi først er kommet så vidt, at der ikke længer er spor af vaklen hos regeringen $i$ de én gang trufne foranstaltninger, og at der fremfor alt ikke fra oven af vækkes eller gives anledning til nye forhåbninger, vil den første hovedbetingelse for sagens onskelige fremme være nået. Alle dens venner kunne derfor ikke noksom onske sig fremtidig bevaret for lignende udtalelser af regeringen som ved den sidste stændersession. ${ }^{77}$ Skal forfatningen revideres, og sprogreskriptet også underkastes en sådan, og noget gives efter i de sydligste sogne (dette noget mener jeg kun kan strække sit til en indskrænkning af den danske prædiken til hver 3'die - 4'de søndag, hvis der overhovedet skal røres derved) er det da uiværksætteligt, at der 
indføres 4 a 5 timers undervisning i dansk i alle skoler til Slien, og at Flensborg kommer med ind under reskriptet tilligemed nogle sogne på vestsiden? Under alle omstændigheder går vi ind $\mathrm{i}$ det nye år med fortrøstning, at der i disse egne, hvor talesproget som bekendt endnu den dag i dag så almindeligt er dansk ikke kan være tale om forandring, mindst af alt gives til pris for en vanartet slægts stemninger og ønsker. Hvad resultatet så ville blive, kan selvfølgeligt selv i de bedre sindede sogne ikke være tvivlsomt. At faren derfor for øjeblikket er forbi, er godt og glædeligt; måtte den for bestandig være fjernet!

Med særdeles højagtelse Deres forbundne $J$. H. Nissen.

Hyrup, d. 27. september 1958. Højvelbårne hr. etatsråd, departementschef Regenburg!

At jeg denne gang skriver til Dem har, som De formodentlig også straks tænker, nærmest sin grund i den indtrufne vakance i provstiet. At Husby ${ }^{78}$ blev ledigt var jo ikke uventet, men derimod, at Munkbrarup ${ }^{79}$ blev det nu. Begge kirker har jeg daglig for øje i min have, og når tankerne vandrede om $i$ fremtids drømme, ønskede jeg ofte, at jeg engang i tiden, såfremt jeg skulle blive inden for sproggrænsen, måtte kunne finde min plads i Munkbrarup. Jeg har ingen oplysninger ved hånden om embedets indtægter, men har stedse hørt, at de skulle være omtrent som i Husby. Hvorvidt jeg vil kunne komme i betragtning til noget af disse 2 embeder, ved jeg naturligvis ikke; men hvis så er, da står uden hensyn til indtægterne min lyst til Munkbrarup. Mod Husby har mine tanker aldrig vendt sig, førend omstændighederne førte dem derhen; men jeg nærer en del frygt for boligen der, den er fugtig og rå, og som jeg antager en ikke stærk konstitution mindre tjenlig - omend jeg nu føler, at de 2 sidste somre har virket gavnligt på ens helbred, og jeg længe har befundet mig vel, så har jeg dog 2 gange haft en alvorlig brystbetændelse at bestå, den ene gang her og skal selvfølgelig såvidt muligt vogte mig for forkølelse, og den er man ikke lidet udsat for på vejen til Husby kirke, der er for kort til at sætte heste og vogn $i$ bevægelse og lang nok til at blive varm på ved at spadsere. Har Hansen end selv været $\mathrm{i}$ det hele taget rask, så har der næsten aldrig været nogen tid, hvor ikke den ene eller den anden $i$ huset har været syg. De ulemper findes ikke i Munkbrarup, som desuden har det store gode, at den ligger stranden så nær, at brug af bade kan blive mulig. Men hvad der er vigtigere, der findes i den menighed så mange danske elementer, at man med interesse for danskhedens fremme ikke kan andet end have lyst til at forsøge, om de ikke skulle kunne fremhjælpes. Som indtægterne er her og trykket af den gæld, jeg det første år måtte gøre både for at kunne leve, da jeg her kun havde 


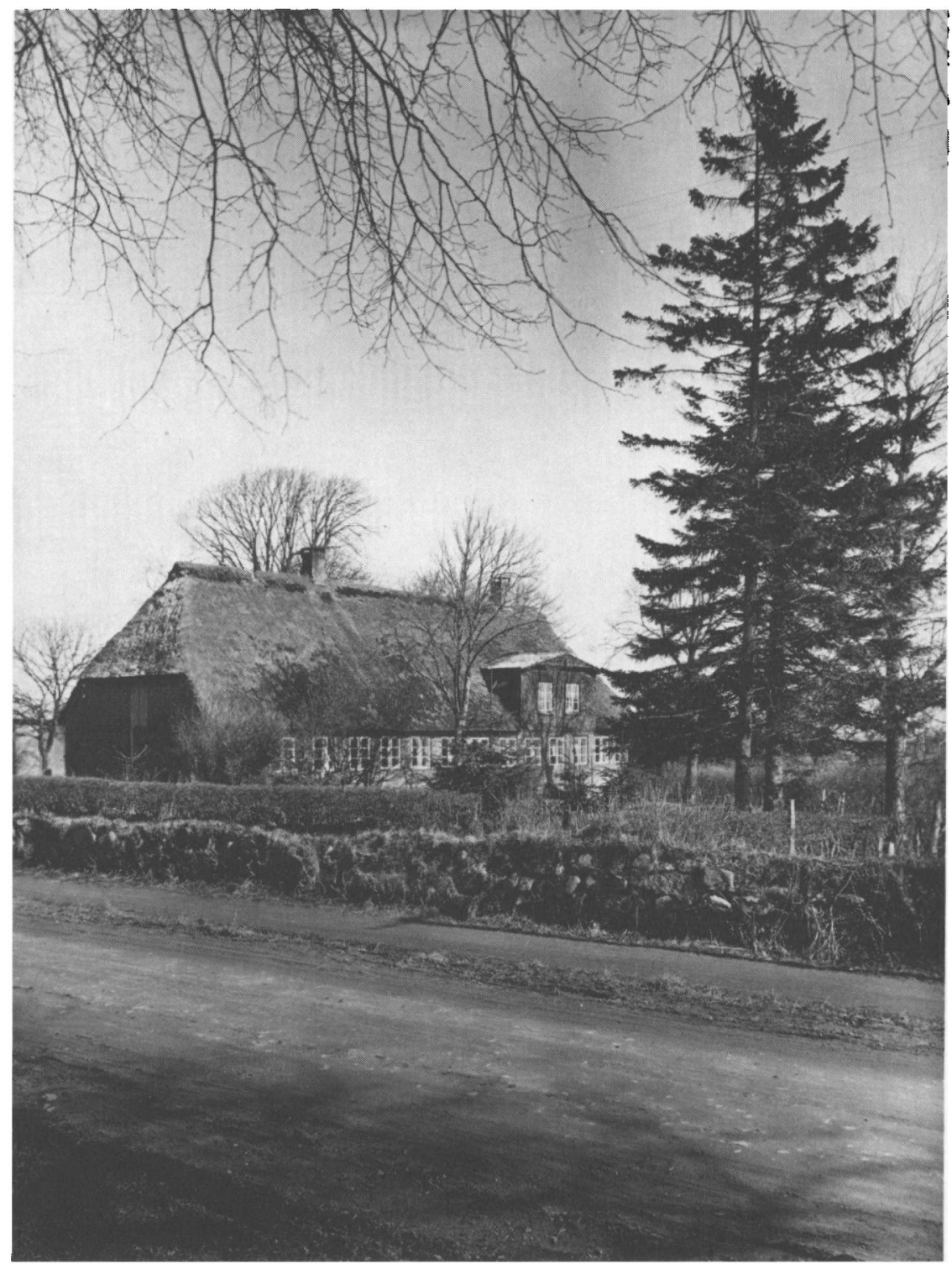

Hyrup prastegård efter restaureringen 1858. (Dansk Centralbibliotek for Sydslesvig).

de halve indkomster og intet fra Odense, og for at anskaffe de nødvendige ting, der udfordres til et landbrug, nødes jeg til at søge forflyttelse, når lejligheden tilbyder sig, omend øjeblikket forsåvidt er mig mindre kærkommet, som menigheden netop nu sætter præstegården her i god og smuk 
stand. Men skal jeg kunne håbe inden altfor fjern en tid at blive lettet for min gæld og sørge tilbørligt for mine børns undervisning, må jeg dog snart se at komme herfra, hvor muligheden istedetfor at rykke nærmere snarere fjerner sig; i det mindste har forrige års ringe høst kun gjort trykket mere føleligt. Iblandt ansøgerne vil De derfor til sin tid formodentlig også finde mig. Er jeg brugbar og De vil gøre Deres indflydelse gældende til gunst for mig til et af de 2 embeder, da beder jeg Dem om muligt at anvende den for Munkbrarup, hvorhen min personlige tilbøjelighed afgjort hælder, når der er tale om forflyttelse i de blandede distrikter.

Det vil måske interessere Dem at høre gangen $i$ en samtale, jeg i fredags havde med Hs. Majestæt. Ehrenreich og jeg tog til Lyksborg nærmest i den hensigt at hilse på ministeren, da vi, førend vi kom på stedet, var erindrede om, at kongen just den dag ville se folk. Vi kom ind, og såsnart kongen havde hørt, at jeg var præst $i$ egnen, kom talen straks på sprogsagen. Han ytrede: Den sag skal man tage med lempe. Vil jeg f. eks. svare en tysker på dansk, så er det straks forkert etc. Men nu skal De høre, fortsatte han "Forgangen dag kørte jeg en tur og i Røul (?) (jeg tillod mig at ytre, jeg antog, det var Ryde) spurgte vi på tysk en mand, der stod der, om vejen til Lyksborg, og så svarede han på dansk: "Ja, her kan vi alle tale dansk « - "Det kan jeg med« og så snakkede vi dansk " Jeg tillod mig dertil at bemærke, at således var det ganske vist, men at Hans Majestæt ingenlunde måtte tro, at folk så åbenhjertigt tilstod det, men tværtimod næsten altid skjulte det, når de stod over for folk uden for bondestanden etc. Han fortalte mig dernæst videre: $O g$ i fjor, jeg var her, så kom denne fyr dernede fra - »hvad er det nu han hedder? « jeg svarede: "Hansen - Grumby ${ }^{80}$ - han holdt en pæn tale til mig på tysk om forandring $i$ sprogsagen, og da jeg havde givet ham besked: »Nej! det sker ikke, det er min vilje, at det bliver, som det er, " vender jeg mig til en tredie, der var med, og spørger ham, hvad han havde på hjerte, og så svarer han mig på dansk: "Ja, jeg har ikke forstået noget af, hvad den anden sagde! « Han talte endnu adskilligt med mig navnlig om forholdene i mit sogn, hvorfra jeg kunne sige, at kongen under oprøret havde en del, som havde været ham hengivne - men afbrød han "også tyskere“ - "Ja vel adskillige, som har gjort dumme streger, men om hvem jeg dog tror at turde sige, at de inderlig ønsker at glemme deres fortid." Dertil nikkede han, og jeg gik mere tilfreds over, hvad jeg havde hørt af majestæten, end om han havde givet mig aldrig så nådigt et svar på min bøn om befordring - hvortil der iøvrigt ingen lejlighed var, da jeg ikke med et ord udtalte, at jeg ønskede forflyttelse. Gid kongen fremdeles ville gøre mange udflugter ud i Angeln og ofte indlade sig i samtale med beboerne. Jeg er naturligvis nysgerrig efter at vide, hvorledes rejsen i dag til Syderbrarup er gået. Jeg mødte i eftermiddag Thomas Schmid - appellationsrådens broder ${ }^{81}$ 
- og han fortalte mig, at han og en del bønder fra Veseby, men ingen fra Rylskov føjede han til med et talende blik, havde været i Nykro for at se kongen køre forbi, som også var lykkedes, at fanen (således udtrykte han sig) skulle vaje fra Husby kirke, at sørupperne, hvor han mente, at kongen ville gøre holdt, havde bygget en æresport (tempora mutantur!), ${ }^{82}$ og at en bonde der ville holde en "Anrede“ ${ }^{83}$. Der var kun få vogne i følget, efter hans sigende 5 a 6, og han havde ikke set ministeren deriblandt. Det făr vi nu snart at høre, hvad for opbyggelige ting Honnigleckerne ${ }^{84}$ har haft at forebringe. Den historie om de Sørup Honnigl. forelæste jeg en dag i sommer tømmerfolkene her, som gav mig selv anledning dertil, da en af dem i tilfredshed over et udført arbejde brugte den af mig ikke før hørte talemåde: "Ach! det hænger jo som en Sørup pessel ${ }^{85}$ dør.“ Den morede dem kostelig, længe efter hørte jeg ved at gå dem forbi, at de endnu opholdt sig med den. Dog jeg har måske nu trættet Dem både med det ene og andet af det skrevne - det må derfor være nok! Jeg håber på Deres velvilje!

Deres med højagtelse forbundne

J. H. Nissen

Hyrup, d. 27. marts 1859. Højvelbårne hr. etatsråd, departementschef Regenburg!

Tiden er jo nu udløbet, $\mathrm{i}$ hvilken dette embede kan søges og menigheden som jeg selvfølgelig meget spændt på, hvem der bliver min efterfølger. Jeg ved ikke alle dem, der søge det, men af dem, der er mig bekendt, kan jeg ikke nægte, det ville være mig kærest, om adjunkt $\mathrm{Krog}^{86} \mathrm{i}$ Flensborg kunne nå det. Han er jo vel en del yngre end i det mindste flere af dem, der aspirerer dertil; men hans lyst til præstelig virksomhed, kristelige sind og hele personlighed gør det efter min ringe formening meget onskeligt, at han måtte kunne erholde et embede her i provstiet, for hvilket jeg ville betragte det som en vinding at tælle ham blandt dets præster. Hans stilling i Flensborg er jo imidlertid i pekuniær henseende allerede så god, at han ikke let kan tænkes tilbøjelig til at søge embede, som er synderlig ringere end dette; navnlig i en fredeligere, mere velsindet menighed som denne tror jeg, at hans valg ville være meget heldigt. Han prædikede på grund af min sygdom her l'ste juledag, dansk, og jeg har af alle, som jeg har hørt ytre sig derom, kun hørt, at de var godt fornøjede: "Han var en feit go' en til at præke, « hed det. Jeg har meget tilovers for hyrupperne, har her stået $i$ et godt forhold næsten til dem alle og vil ikke så aldeles let kunne løse det bånd, som binder mig til dem. Jeg ønsker derfor også endeligt, at de i min eftermand må finde en mand, som foruden slige egenskaber også har den, at han besidder nogenlunde gaver til at omgås 
bønder og vinde deres fortrolighed. Det ligger blandt andet også menigheden på hjerte, og derfor hører jeg ofte, når de spørger mig: „Nå, er der endnu ikke nogen sigelse af, hvem vi får? « På mit lidet tilfredsstillende svar, forsåvidt jeg ingen mening har derover, men dog beroligende, idet jeg henviser dem til, at ministeren, som jo kender dem, nok vil sørge på det bedste for dem - svare "Ja, men det er nu den omgang." Så naivt, som det lyder, så meget har det at betyde. Jeg har desværre $\mathrm{i}$ de år, jeg har været her, $\mathrm{i}$ degnen haft et afskrækkende eksempel på, hvad skade og fortræd i mange retninger en uheldig personlighed, trods dygtighed, formår at udøve. Han har været mit kors her, og når jeg ikke har udrettet mere, end jeg har, og jeg føler, det er kun lidt, så tror jeg ikke, at jeg gør ham uret, når jeg mener, at han er for en stor del skyld deri. Også på grund af det beklagelige forhold, hvori han står og må stå, så længe han bliver, som han er, til menigheden, er det af så megen større betydning her, at præsten er en mand, som de kan have agtelse og velvilje for, og som de kan nærme sig til med tillid, at ikke alt skal blive nedbrudt. - Gid De da blandt ansøgerne må være heldig til at finde den bedst skikkede. - Jeg kommer først d. 10'de april til at holde afskedsprædiken, da jeg ikke af kirkevisitatoriet kan blive introduceret før d. 17'de i Husby. Anden der er jo vistnok i de senere år blevet en del bedre; gid det fremdeles må gå fremad i den ønskelige retning. For den del, som De måtte have i min befordring dertil, bringer jeg Dem min tak. Da ministeren viste mig den uventede opmærksomhed straks efter min udnævnelse at tilskrive mig det, greb jeg i mit svar lejligheden til at henlede hr. excellencens opmærksomhed i almindelighed på Krog; jeg troede endnu dengang, at Ehrenreich ville søge det, og at han i så fald ville gå forud for alle andre. Han søger det jo ikke; hvem der nu kan være den nærmeste, ved De vel bedst. Mit ønske er kun, at valgets udfald også må være det bedste, og deri samstemmer De sikkert! De vil derfor vistnok også med velvilje have læst disse linier, om De end ikke kan tillægge dem nogen vægt.

Med højagtelse Deres forbundne $J$. H. Nissen

Husby, d. 28'de jan. 1861

Højstærede hr. etatsråd.

Uden at jeg vil indlade mig på bedømmelsen af klogskaben ved de sidst trufne foranstaltninger $\mathrm{i}$ sprogsagen eller hengive mig til ørkesløse betragtninger derover, kan jeg dog ikke andet end for Dem udtale min dybe beklagelse såvel over patentet ${ }^{87}$ som cirkulæret. Jeg for mit vedkommende havde meget hellere set, at der var indrømmet et større timetal til tysk i skolerne. Hvorledes vil det kunne undgås for fremtiden? - end at konfirma- 
tionen således er sønderlemmet og dens sidste akt mere eller mindre degraderet til et forargeligt skuespil. Selvfølgelig vil alle forældrene i disse egne komme og forlange den på tysk, og præsten står da værgeløs, må trods alle modforestillinger og sit hjertes modstræben bøje sig under åget, der snart kan blive det svareste, der endnu er lagt på ham. 4 af fædrene har været hos mig og udtalt deres ønske; de 3 af dem har indrømmet mig, at denne foranstaltning er kommet dem som himmelfalden, derom havde de ikke drømt; indrømmede, at det for børnenes vedkommende er unaturligt og forkert, for præsten svært og trykkende; et par af dem, - at de ikke for deres egen skyld forlanger det, men "de andre ville det jo", "de kunne ikke gå derimod“, "den sag er besnakket mellem dem“, "de ville alle komme" - og kommer det så tilsidst: »det er dog så net, at vi kunne gå til alters med vore børn.« Efter al sandsynlighed vil jeg af 28 konfirmander få 2 på dansk, den ene er plejesøn af Traustedt, $^{88}$ som imidlertid skal have biskoppens dispensation, og den anden en dreng fra fattigvæsenet. Opnår hin ikke dispensation, formodentlig slet ingen! - Således i år og til næste år - hvis vi er her - naturligvis ligeså. Dansk vil blive aldeles exceptionelt, og for så vidt det vil blive brugt, indskrænket til præste- og skolelærerbørn eller de fattiges og ringest begavede! Skønne udsigter! Endog i Hyrup er af de 4 konfirmander, Borch i år har, 3 forlangt konfirmeret på tysk (den 4'de er på fattigvæsenet) og i Rylskov har af $6-2$ forlangt det og ventes flere at ville komme. Men det er, som vore tyskere siger det, kun en "Anfang “; det næste er, at der arbejdes til, også er tysk forberedelse til konfirmationen og de deraf følgende konsekvenser, og de kunne måske komme og være os meget nær, nu det ser ud til, at de andre magter arbejder for fredens bevarelse, og hvorledes vil så flere indrømmelser kunne undgås, nu man så vel er kommet på glidebane? At iøvrigt patentet såvelsom cirkulæret lader mange spørgsmål stå ubestemte hen, ved De sikkert bedre end jeg. På onsdag skal der i den anledning holdes et konvent i Flensborg. Andragende til regeringen til tvivlens løsning kan ikke udeblive. Den høje tone, hvori Tyskland istemte ved de første krigsrygter, tror jeg, er i de senere dage meget nedstemt; de drømte allerede om at se præster og skolelærere tage Reich aus. Da Traustedt for ca. 8 dage siden kørte til Grumtoft, traf han på vejen mellem Lyshøj og Grumtoft nogle snekastere. Han hørte, da han kørte forbi dem, en brummen, som han antog gjaldt ham, vendte sig om og spurgte, hvad de sagde: „Ich seg, wollen Se öwer dat Haf". Han forstod det ikke straks og svaret gentoges under de andres skoggerlatter. Som bidrag til hr. Raynals's ${ }^{89}$ vidunderlige undersøgelser følgende: Igår 8 dage var Traustedts andenlærer i Grumtofte i kirke - dansk -; da han er kommet lidt fra kirken, ser han en "pæn" mand stå noget foran sig på vejen, som om han ventede på hans komme; var nok til at samtale kan 
indledes, spørger R., hvorfra han var? - Fyen. Hvor han nu opholdt sig? i Oksager. Hvor det lå? Hos hvem? Hvorledes skolelæreren var for en? Om der taltes dansk i den egen? Hvem der var prast? Er det en dansker eller tysker? Hvorledes står han sig i sognet? Driver han politik? - Så lidt til Grumtoft $i$ samme dur! Hvorledes provsten var lidt? Det var nok en hård mand!! Om de i Grumtoft kunne tale dansk? Fortalte dernæst om en kone, han havde talt med på vejen, der godt kunne forstå ham, når han talte dansk, men ikke kunne forstå præsten! Af børn og fulde folk skal man jo høre sandheden, eller hvad hr. R. synes at hylde det, af kællinger og drenge! Det er eins Bier! Lørdag aften kom han til Grumtoft, tog ind på kroen og efter der og på veje og stræder at have udforsket forhold og tilstande, går han søndag eftermiddag til provsten og præsenterer sig som udsending af den engelske regering! Det er oprørende. Hos mig har han ikke været, og jeg ved ikke, om han har været her i sognet, men jeg ved, at hvis han kommer til mig, skal han få besked. Han har som dreng fảet mange klaps og spark på sin tykke bag, det eneste han dengang udmærkede sig ved - og gamle minder kunne let vågne op igen ved gensynet! At vi, efter at der spores liv i regeringen og i folket, er ved godt mod er vel selvfølge! Kun fremad i sa mme å nd!, ivrig rustning og snarlig indkaldelse af det unge mandskab, navnlig fra Mellem- og Sydslesvig. De er på ingen måde at stole på; "de slår ud" siger de tro her $\mathrm{i}$ sognet, så snart lejlighed gives. En af mine kirkeværger - blandt de giftigste $t$ (yskere) - kunne forleden, han var her, ikke begribe, at der, som man allevegne hørte, varfare for en europæisk krig: Det angik jo kun "die Herzogthümer". Af mange ytringer ved jeg, at man her har ønsket krig - nu synes det at begynde at gå op for dem, at de let kunne "trække den korteste ende", som de siger. Bliver freden bevaret, er der vel fare nok for, at vi kommer til det. - Lev vel!

Deres med højagtelse forbundne J. H. Nissen.

Husby, 1862 17/3. J. H. Nissen har noget los gald til venner fra de forste är $i$ Hyrup. Han er nu blevet rykket for tilbagebetaling og for at fả galden samlet. sparger han Regenburg, om regeringen kan bevilge ham et lån på indtil 400 rdlr. på rimelige afbetalingsvilkår og med sikkerhed i en livsforsikringspolice på 1500 rdlr. ... "Foruden at børnetallet nu er vokset til 6, og jeg daglig har 13 a 14 personer at ernære og 6 af dem at betale løn, var min høst mindre god i fjor og mistede jeg ved uheld 2 malkekøer o: 120 a 30 rdlr. ekstra ud af lommen dog nok herom! Hjemmetyskerne forholder sig, så vidt jeg mærker, ganske stille for tiden her i sognet. Selvfølgelig begynder nu renderiet om at få børnene konfirmeret på tysk (sogari Rylskov fryder de nu Ehrenreichs sjæl til 


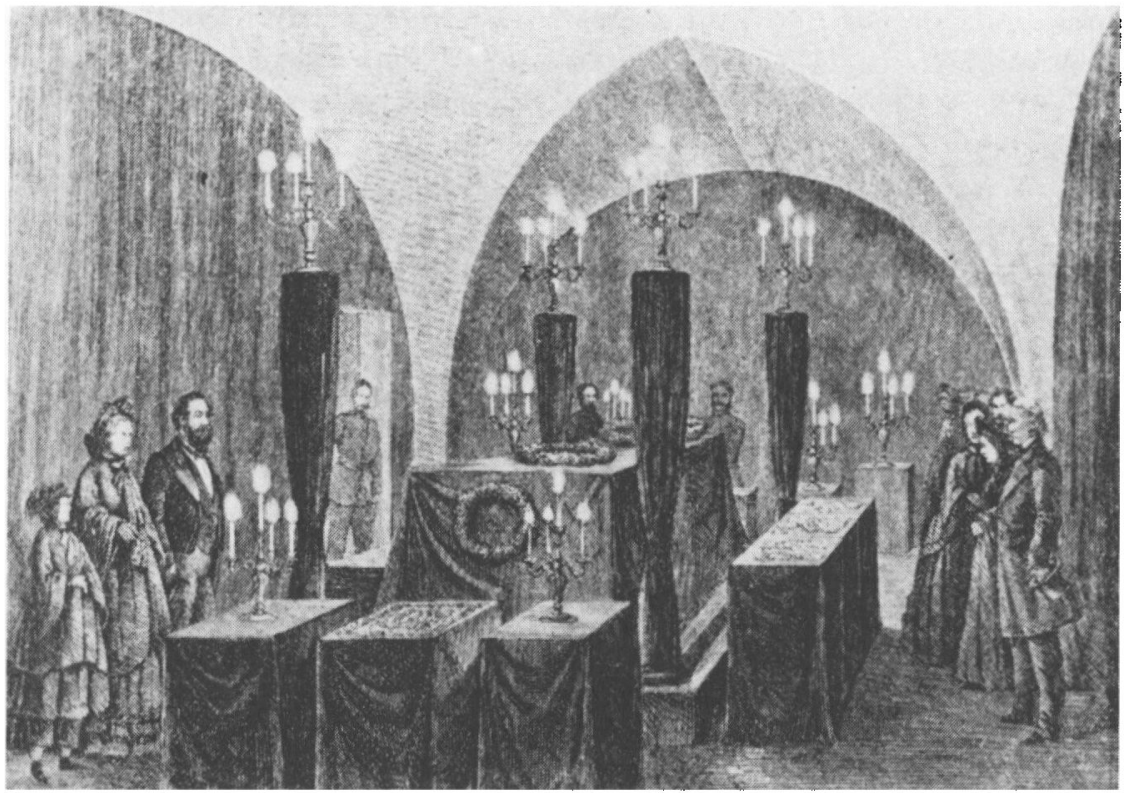

Kong Frederik VII pả lit de parade pả Lyksborg. (Efter Illustreret Tidende).

afsked med alle 4 at forlange tysk konfirmation!), og tiden nærmer sig atter, at man skal bide i dette sure æble! Det er, kan De tro, hårde konditioner! og hvad skal enden blive herpå! ... N. omtaler her nogle unge karle, som efter at have varet på missionsskole i Hermansburg, rejser som missionarer til Afrika. "... Sidste år var kommunikanternes antal det største, det har været siden oprøret -1050 . Til en til maj ledig huslærerplads i Husby, som averteredes i Itzehoeren, ${ }^{90}$ har der meldt sig aspiranter fra alle Gauen $i$ det "grosse Reich ", ${ }^{1}$ der siges endog en fra Ungarn! Hvem, der bliver den lykkelige, har jeg ikke kunnet få at vide. I Markerup skal også nu i stedet for gouvernante holdes en gouvernør, naturligvis af racen den ægte. Sagerne går deres skæve gang! Degnen Ebbesen i Hyrup har været så heldig at få for 8 dage siden en ansættelse i Jylland - Vendsyssel! Godt for ham og mine kære hyrupper. Skulle han have haft pension af menigheden, var der ganske sikkert kommet en kontrademonstration til gunst for ham - "så hellere beholde ham ", "vi kan let få en ringere « etc. Jeg besøgte Hagerup igår. Han har det ikke godt; i de sidste dage var hans fødder begyndt at hovne, et symptom, som ængstede ham og det vel desværre ikke uden grund. Plenge! ${ }^{93}$ ak og ve! det er grueligt.

Husby, 1862 2/6. J. H. Nissen beder Regenburg undersoge, hvorfor han endnu ikke har hort om det ansogte lån. "... Nyt uheld har jeg atter i disse dage haft, 
idet jeg har mistet en af mine bedste køer - i fjor 2 -; dette tab med den $\mathrm{i}$ Husby gjorte erfaring, at den jord, som er tilbage til at drives af præsten, er for ringe af kvantitet til at holde heste og det øvrige folkehold, har i den sidste tid stærkt vakt tanker hos mig om at opgive det hele Landwirtschaft og at indrette os på købstadsvis - med hvor mange gener det end er forbundet. Efter al sandsynlighed gør jeg meget snart skridt til at få hele resten bortlejet og at blive reduceret til husmand "med bolig og kålgård". Forresten alt ved det gamle, dog synes jeg i år at skulle have den glæde at få hold på en del af sidste års konfirmander, idet flere af dem endnu stadig besøger den danske gudstjeneste; så vidt var jeg for længe siden kommet i Hyrup. Det er dog her et lille skridt fremad, hvis det ikke bliver gået tilbage igen. Hos provsten, ${ }^{94}$ som jeg besøgte i søndags, var det ikke godt. Claudia lå i sengen, hendes skranten har nok desværre en dybere grund. Anbefalende mig til Deres velvillige bistand forbliver jeg

Deres med højagtelse forbundne J. H. Nissen.

\section{NOTER OG HENVISNINGER}

Det bemærkes, at de i erindringerne og brevene omtalte sognebørn i Hyrup og Husby sogne i almindelighed ikke er søgt identificerede.

\section{Indledning}

1. A. Kann Rasmussen: Soranerbiografier 1822-1900, s. 55.

2. A. Kann Rasmussen: Anf. arb., s. 47 og Holger Hjelholt: A. Regenburg, s. 12.

3. De personalhistoriske oplysninger stammer fra Wibergs og Elvius' prastehistorier og fra Nissens brev til Regen burg 27/8 1851. Se endv. Årbog for Historisk Samfund fra Odense og Assens Amter 1917, s. 17.

4. A. Regenburgs privatarkiv opbevares i Rigsarkivet.

\section{Erindringer}

1. M. A. Monrad, 1819-93, auditør og regnskabsfører for 6. dragonregiment, student fra Sorø 1837.

2. H. C. Fuhrmann, d. 1856 , oberst ved den kgl. artilleribrigade.

3. Sprogreskripterne blev gennemført foråret 1851 .

4. Th. A. J. Regenburg var departementschef $\mathrm{i}$ det slesvigske ministerium og havde hovedansvaret for gennemforelsen af sprogreskripterne; jfr. iøvrigt Holger Hjelholt: Anf. arb. og samme: Den danske sprogordning og det danske sprogstyre i Slesvig mellem krigene (1850-1864).

5. Arden er formentl. ogenavn for en af kollegerne.

6. C. C. J. Asschenfeldt, 1792-1856, sogneprest ved Skt. Nicolai, Flensborg og provst i Flensborg provsti, konst. superintendent (biskop) 1850-54 for den tyske del af Sønderjylland.

7. Jacob Hansen, 1819-87, præst i Grumtoft 1851-56.

8. Jens Back, 1779-1854, prast i Hyrup 1834-51.

9. Lorenz Simonsen, 1800-72. Han, der var født i Flensborg, havde været præst ved Frederiks 
tyske kirke i København, før han 1836 blev præst i Husby. Han havde i København sluttet sig til Grundtvig og havde sammen med Lindberg holdt gudelige forsamlinger; se H. F. Petersen: Fra sydslesvigske præstegårde, s. 132. Se endv. Kirkehist. Saml. 4 rk., bd. III, s. $223 \mathrm{ff} o g 241 \mathrm{ff}$.

10. Lars Hansen, 1788-1876, degn og larer i Husby 1822-50 og 1864-66; jfr. L. S. Ravn: Lærerne under sprogreskripterne, 1851-1864, s. 203.

11. Elise Sophie Frederike Gøricke, født i Paris, 1806-70.

12. Aleth Sophus Hansen, 1817-89, præst i Husby $1850-58$.

13. Hermannsburg i nærheden afCelle i Hannover, hvor pastor Harms 1849 havde grundlagt en missionsanstalt.

13a. Rud, lokalitet i Føns sogn på Fyn.

14. N. S. Brock, 1803-85, oberst, chef for 5. dragonregiment i Randers.

15. C. A. J. Fibiger, major ved 5 . dragonregiment.

16. M. F. Blauenfeldt, 1799-1874, herredsfoged i Hütten herred 1850-64.

17. Jfr. note II. 10.

18. Peter Jensen, Oksager, 1824-89, landmand og politiker, sen. medlem af den flensborgske kredsdag og den preussiske landdag. I Schleswig-Holsteinisches Biografisches Lexikon, bd. IV, s. $120 \mathrm{f}$ nævnes han ikke som medlem af den slesvigke stænderforsamling.

19. Andreas Samuelsen, 1822-89, der var uddannet på Skårup og Jelling seminarier, var degn, organist og lærer i Husby 1851-64, derefter til 1886 i Oversø. Se L. S. Ravn: Anf. arb., s. 240 og Kirkehist. Saml. 4. rk., bd. III, s. 235 f.

20. Harald Emil Heinrich Daniel von Neergaard, 1826-67, kst. præst i Kliplev og StarupGrarup 1864, prast i Aller 1865-67; jfr. note III 76.

21. gennemprygler.

22. Godsejer, etatsråd Morits Hagemann overtog 1838 Udmark, Ohrfeld i Eskris sogn; se Trap: Slesvig, s. 504.

23. Otto Nic. Henning Peters, 1819-1905, præst ved Marie kirke i Flensborg 1849-96, kst. provst 1864, provst 1866.

24. Baron Carl Frederik Blixen Finecke, 1822-73, var fra 2. dec. 1859 til febr. 1860 udenrigsminister og minister for Slesvig i ministeriet Rotwitt.

25. Christian Juel, 1828-1914, jurist og politiker, en af Regenburgs nære medarbejdere, 1863 overappellationsråd i Flensborg.

25a. Ang. Husby-folkenes opførsel, se: Kirkehist. Saml. 4 rk, bd. III, s. $266 \mathrm{f}$.

26. Baron W. F. Wedell-Wedellsborg, 1827-1914, konst. amtmand i Flensborg 1856-59, amtmand $1860-64$.

27. Veseby i Hyrup sogn, ca. $4 \mathrm{~km}$ vest for Husby.

28. Immanuel Barfod, 1820-96, prast i Sørup 1854-64.

29. Kr. Karstensen, 1809-82, præst i Dybbøl 1839-48 og 1849-57, præst og provst i Broager 1857-64, prast i Gjelsted 1864-82.

30. Holger Lorentz Basse Fønss, 1807-94, fra 1862 provst i Middelfart.

31. Ernst Wilster, 1808-81, generalmajor, 1867 general.

32. Jfr. note II 9 og 11 .

33. Fr. Wolfhagen, 1818-94, minister for hertugdømmet Slesvig 1856-63.

\section{J. H. Nissens breve til A. Regenburg}

1. Jfr. note I.2.

2. Theodor Steenbuch, 1816-91. Blev 1854 sogneprast ved Skt. Hans kirke i Odense.

3. C. E. Bardenfleth, 1807-57, var 1842-48 stiftamtmand i Odense, 1851-52 minister for Slesvig.

4. Jfr. note II.1. 
5. Jfr. note II.6.

6. Jens Chr. Emil Reimuth, 1818-75, blev 1852 præst i Hjoldelund.

7. Theodor Sextus Kühnel, 1813-1904, blev 1853 præst i Ulsnæs.

8. Consilium abeundi - råd om at flytte.

9. Officielt: Den slesvigske Centralkasse i Flensborg.

10. L. S. Ravn har ikke navnet i tidl. anf. arb.

11. Jfr. note II.3.

12. Lærer her var Thomas Jessen, f. 1791, degn og lærer i Hyrup 1815-52; jfr. L. S. Ravn: Anf. arb. s. $213 \mathrm{f}$.

13. Jfr. note II.6 og III.5.

14. Fr. Wolfhagen, 1818-94, amtmand over Flensborg amt 1850-56, derefter minister for Slesvig til 1863. Delte Regeburgs synspunkter m.h.t. sprogpolitikken; jfr, note II.33.

15. Ottemænd og kirkejurater har andel i det kommunale og kirkelige styre.

16. Hans Chr. Lassen, 1808-72, præst i Adelby 1850-64.

17. L. N. v. Scheel: Fragmente in zwangslosen Heften von..., hft. 1-2, København 1850-51.

18. Jfr. note I.I og II.1.

19. d.v. s. demagogisk agitation.

20. Se Sonderjyllands Historie IV, s. $425 \mathrm{f}$.

21. Rechensmann= regnskabsmand, bestillingsmand i Flensborg amt og en del af Gottorp amt; svarer nærmest til sognefoged, men har et større område, en trint = 3 sogne, under sig; jfr. Trap: Slesvig 1, s. 70. Rechensmann i Hyrup er Marquard Gregersen, Veseby.

22. Manteloffer - tiltrædelsesoffer til anskaffelse af præstekjole. Iflg. Jensen: Kirchliche Statistik, 1841, s. 968 var dette offer i Hyrup sogn 40-50 rdlr. Se endv. Callisen: Kurzer Abriss des Wissenwürdigsten aus den Prediger und sein Amt in... Schlesw. Holst. betr. Verordnungen, 1843, s. 53.

23. Se note II.8.

24. Opgorelse, skifte.

25. Se note II.12.

26. Se Sønderjyllands Historie IV, s. 434 f.

27. Carl Moltke, 1798-1866, minister for Slesvig 1852-54, konservativ helstatsmand.

28. Ernst Wilster, 1851 oberstløjtnant, 1852 chef for 3 . forstarkningsbataillon; se i øvrigt note II.31. Ang. belejringstilstand, se Sanderjyllands Historie IV, s. 418.

29. Visitatoriet, der bestod af amtmand og provst, førte tilsyn med kirkevæsenets økonomiske anliggender.

30. Jacob Hansen, 1819-87, diakon i Grumtoft 1851-56. Blev 1853 gift med Madsine Sophie Levinsen; jfr. note III,50.

31. Ministercirkulæret af 22. maj 1852; jfr. Holger Hjelholt: Danske sprogordning og sprogstyre..., s. 60. 2. pinsedag var 31. maj.

31. I Sørup sogn.

32. Fikker $=$ lommer.

33. Ang. det slesv.-holst. bibelselskab se: H. F. Chalybæus: Sammlung der Vorschriften und Entscheidungen betr. das schlesw.-holst. Kirchenrecht, 1902, s. $881 \mathrm{f}$.

34. Chr. Christiansen, 1801-69, præst i Medelby, Kær hrd., Tønder amt 1837-69.

35. Jes Siemsen el. Simonsen, 1773-1859, præst i Hanved 1823-54.

36. Hans Andresen, 1797-1858, præst i Grumtoft 1851-58.

37. Ang. Boesens salmebog se: Slesvigs delte Bispedømme, s. 315 f. Ulrik Sechmann Boesen, 1797-1867, biskop over Slesvig 1854-64, medudgiver af den Meyer-Boesen'ske salmebog, aut. 26/2 1847 til brug for det dansktalende Slesvig. Om Boesen i øvrigt se H. F. Petersen i Slesvigs delte Bispedømme, s. 327-73.

38. For øvrigt mener jeg, at Th. J. bar ødelægges.

39. Aleth Hansen, se note II.12. 
40. Eiler Henning Hagerup, 1817-63, prast i Solt 1850-63, stænderdeputeret og sprogmand.

41. Johs. Marcus Ebbesen, 1814-87, larer i Dollerupskov, Grumtoft sogn 1851-53, degn og larer i Hyrup 1853-62; se L. S. Ravn: Anf. arb., s. 196.

42. Befangen- hildet, havde forudfattet mening.

43. Oksager.

44. Andreas Martin Franzen, 1831-1910, andenlærer i Hyrup 1852-53; se Ravn: Anf. arb. s. 198.

45. Jacob Philipsen, f. 1795, lærer ved Tvedskov biskole i Adelby sogn 1840-41; jfr. Børge L. Barløse: Larerstanden i Sydslesvig fra reformationen til 1864, nr. 2795.

46. Herredsfuldmægtigene, hvoraf der var $5 \mathrm{i}$ hvert af de flensborgske herreder, udnævntes af amtmanden efter indstilling af herredsfogden. De forte tilsyn med skatteoppeborslen og med amtets, herredets og kommunernes regnskaber; jfr. Trap: Slesvig, s. $458 \mathrm{f}$.

47. Andreas Chr. Johs. Schmid, 1815-93, jur. professor i København 1851, i Kiel 1853 , præsident for slesv. stænderforsamling 1853; se Bricka: Biogr. Leks, og Knudsen og Kretzschmer: Sydslesvig II, s. 256.

48. Se note III.16.

49. Joh. Gottlob Ehrenreich, 1821-70, præst i Rylskov 1850-64.

50. Lorens Johs. Levinsen, 1821-1905, præst i Kværn 1852-59; jfr. note III.30.

51. Frederik VII er født 6. okt. 1808.

52. Tysk privatskole, se: Flensburg, Geschichte einer Grenzstadt, s. 332 og Flensborg Bys Historie II, s. 126. Leder var Chr. Petersen.

53. Hans Lassen, f. 1830, dim. Skårup 1850, hjælpelærer i Husby 1851-54, la rer i Torsballe, Havetoft sogn 1854-71; jfr. Ravn: Anf. arb. s. 223.

54. Comiteen for oprettelse af danske folkebiblioteker i Slesvig; se Slesvigske Provindsialefterretninger, bd. 2, s. $393 \mathrm{ff}$.

55. Den senere rigsdagsmand $H$. A. Krüger, Bevtoft, der blev valgt i Gram distrikt.

56. Peter Hinrichsen, gårdmand i Meden, Valsbøl sogn, stænderdeputeret for de mindre landejendomsbesiddere i Flensborg valgdistrikt; se Sønderjyske Årbøger 1925, s. 279 f og 1928 , s. 168.

57. Der var købstadsfrihed for at lette samfærdslen, samkvemmet.

58. Dygtige.

59. Handelen.

60. Se Sønderjyllands Historie IV, s. 434.

61. Var kommet til at holde af mig.

62. Edspræediken.

63. Anstødelig.

64. Se note III.7.

65. Herm. Peter Johs. Hacker, 1799-1853, præst i Sørup 1850-53.

66. Se III.40. Hagerup blev 2. gang gift med Betzy Lauritse Thomsen den 16. sept. 1853.

67. Immanuel Barfod, 1820-96, præst i Overse 1851-54, i Serup 1854-64.

68. Peter Thomsen, 1807-87, præst i Munkbrarup 1839-58.

69. Rygtet er ikke bekræftet ved eftersyn i dødsregistrene for Stenbjerg og Grumtoft.

70. Se note III.44.

71. Se note III.37. Ang. indførelse af dansk salmesang ved gudstjenesterne se: $\mathbf{H}$. Hjelholt: Dansk sprogordning og sprogstyre..., s. 100.

71a. Carl Ludv. Mohr (1820-72), præst i Ølsby-Farensted i Strukstrup herred.

72. Uafklaret.

73. Embedet i Hanved blev 1855 besat med Immanuel Friis, 1819-1911.

74. Den sen. kendte skolebogsforfatter Johs. Holst, 1833-97, var hjælpelærer i Hyrup 1855. Ravn: Anf. arb. s. 206. 
75. Set ud fra et religirst standpunkt er frugterne af evangeliets forkyndelse i et os uforståeligt sprog bedrovelig, ja himmelråbende.

76. Degn Ebbesen har 1855 noteret i Hyrup skolekrønike, at skolen havde flg. undervisningsmateriale: Et verdenskort, et Europa-kort, 15 danske bibler, 38 danske nye testamenter, 20 danske salmebøger (Boesen), 60 ekspl. af Hjorts Børnevenner, $47 \mathrm{ekspl}$. af Balslevs katekismus, $56 \mathrm{ekspl}$. af Balslevs bibelhistorie. Efter 1864 blev undervisningsmaterialet solgt til pastor Neergaard i Aller og til Fredericia.

77. Jfr. Sonderjyllands Historie IV, s. $448 \mathrm{f}$.

78. Provst Aleth Hansen flyttede 1858 til Grumtoft.

79. Se note III.68. Det var Lorentz Johs. Levinsen, der fik Munkbrarup.

80. Den slesv.-holst. sindede stænderdeputerede og medlem af rigsrådet Andreas HansenGrumby.

81. Se note III.47.

82. Tiderne skifter.

83. Tale.

84. Honningslikkerne.

85. Pisel - storstue.

86. Jens Krog, 1832-77, 1856 adjunkt ved Flensborg latinsskole, 1859 diakon i Grumtoft.

87. Ved patent af 9 . jan. 1861 overlodes det forældrene $i$ mdet blandede bælteu at afgøre, på hvilket sprog deres børn skulle konfirmeres. Se Sønderjyllands Historie IV, s. 489.

88. Jørgen Petersen Traustedt, 1827-88, lærer i Oksager, Husby sogn 1852-63; jfr. Ravn: Anf. arb. s. 247.

89. Harry Rainals, f. 1816. Var elev på Sorø Akademi 1829-33. Var i engelsk tjeneste. Se: Kann Rasmussen: Anf. arb., s. 42.

90. Itzehoer Wochenblatt.

91. Alle landskaber i det store rige.

92. Han var larer i Oddense, Viborg amt 1862-86; jfr. Ravn: Anf. arb., s. 196.

93. Johs. Chr. Ludv. Plenge, 1822-89, præst i Sotrup, Gottorp amt 1851-60, i Ødis 1860-62, hvorfra han afskediges efter ansøgning; jfr. Bricka: Biogr. Leks.

94. Aleth Hansen. 
